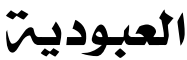

لشيخ الإسلاهر: أحمد بن تيميتّا

"SVYA - 7II"

دراست وتحقيق

(من أول الكتاب حتى نهايت فصل الأمر بالمعروف فئ

والنهي عن المنكر)

د. منيرة بنت عبد الله الراجيي

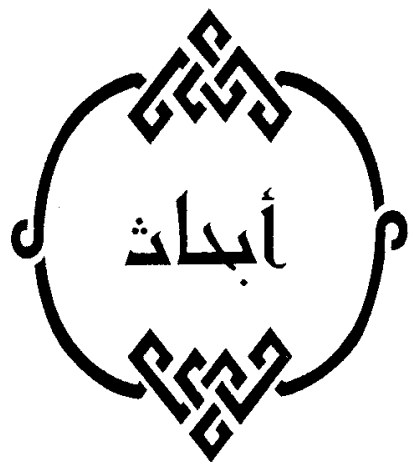

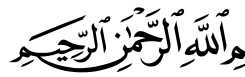

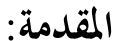

إن الحمد لله، نحمدُه ونستغفره ونستعينه ونستهديه، ونعوذُ بالله من شرور أنفسنا

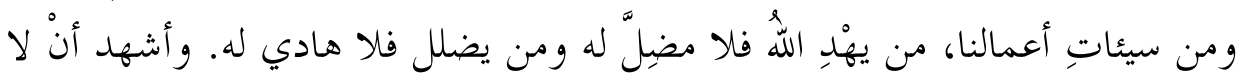

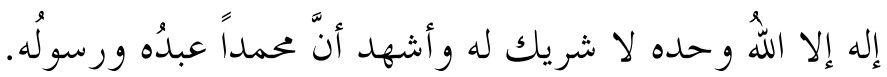

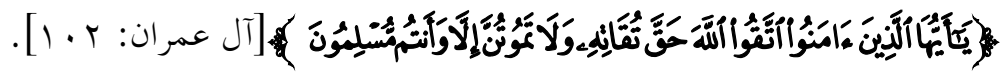

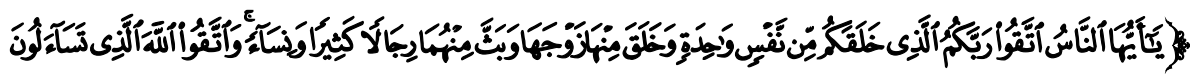

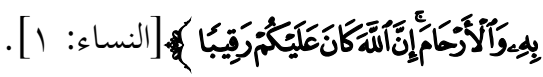

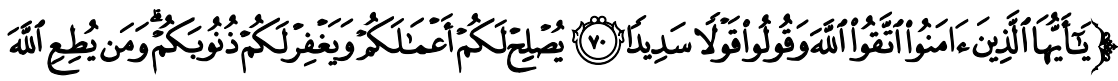

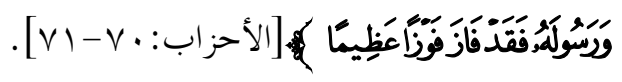

(") أستاذ العقيدة والمذاهب المعاصرة المساعد - كلية الشريعة والدراسات الإسلامية - جامعة القصيم. $-1 \vee 0$. 
أما بعد: فالعلم حياة النفوس و كمالها، و العلم يشرف بشرف موضوعه , ولا أرفع قدرا، وأوجب مطلبا من شرف العلم بالله - سبحانه - في ربو بيته وأسمائه وصفاته، وحقوقه، وأعظم حق الله - تعالى - على عباده أن يعبدوه و لا يشركوا به شيئا، وهو الغاية من خلق الإنس والجحن، كما قال - تعالى -: الوَمًَا خَلَقْتُ

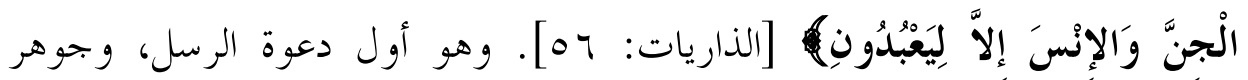
رسالتهم، والغاية من بعثتهم، وأول واجب على المكلف وآخره، ولذلك فإن أنفع ما للمسلم، وأولى ما صرفت به الأوقات، وبذلت في بحثه الطاقات هو هذا المقام العظيم.

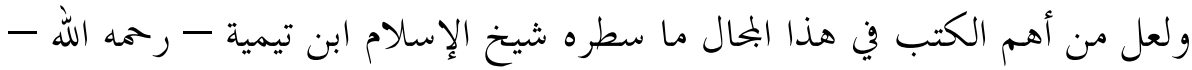
فقد آتاه الله علما وفقها، و حفظا، وبيانا، قلما يوجد في غيره، و كان معتمده فيما صنفه من تصانيف نصوص الوحيين، فسدده الله في آرائه، ورزقه الصواب في أقواله، وهذه نعمة يمن الله هـا على من يشاء من عباده.

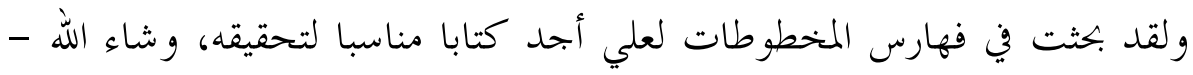
تعالى - أن أعثر على نسخة غخطوطة لرسالة موسومة بـــ "العبودية " لشيخ الإسلام ابن تيمية - رحمه الله - ذكر فيها تفاصيل كثيرة عن العبادة وحقيقتها وأنواعها ذكرا مؤصلا، فلما قرأقا رأيت أهمية تحقيقها، فتوجهت همتي بعد الاستخارة، والاستشارة إلى دراسة هذا السفر العظيم، وتحقيقه، و التعليق عليه.

$$
\text { أهمية الموضوع وأسباب اختياره: }
$$

ومن أهم العو امل التي دفعتي إلى تحقيق هذا الكتاب ما يلي:

1- أن هذا العمل محاولة لتحقيق كنــز من كنوز التراث الإسلامي 


$$
\text { العبودية لشيخ الإسلام: أحمد بن تيمية "اר؟ - }
$$

و خدمته بما يجب.

Y- قيمة الكتاب العلمية: فهو غختصر يكاد يكون من أهم الكتب المصنفة في هذا الباب، ومع اختصاره، إلا أنه اشتمل على جميع المسائل المتعلقة هذا الأصل العظيم، مع دقته في تحري الحق، وإيصاله للناس من منبعه الصافي: الكتاب و السنة.

r- - منـــلة شيخ الإسلام العلمية وشهرته الواسعة، ولعل من أهم ما يبين هذه المنـــلة آثاره المنتشرة في الآفاق، وثناء كثير من العلماء عليه، وإقرارهم له له بالأمانة والحفظ حتى أنه كان يلقب بشيخ الإسلام. ع - - أن هذا الكتاب في حاجة إلى دراسة وافية لمباحثه وتحقيق علمي لنصه ؛ لأن

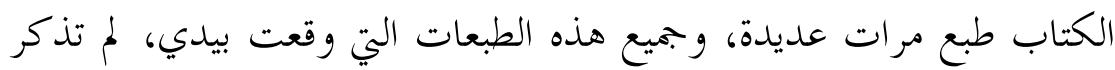
حتى النسخة التي أعتمد عليها في طبعها فضلا أن تقدم الخدمة المطلوبة في تحقيق الرسائل العلمية. ه - تشجيع أهل العلم أصحاب الاختصاص الذين استشرقم في شأن تحقيق هذا الكتاب، ودراسته.

צ- حاجة الناس الماسة إلى فقه هذا الأصل العظيم، فإن حاجتهم إليه فوق كل حاجة، وضرورةم إليه فوق كل ضرورة، فلا راحة، ولا طمأنينة، ولا أنس، ولا سعادة، إلا بأن يعرف العبد ربه بألوهيته، وربو بيته، وأسمائه وصفاته.

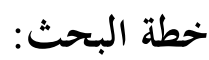
اقتضت طبيعة العمل في هذا الكتاب تقسيمه إلى قسيمين رئيسيين: 


$$
\text { الأول: القسم الدراسي }
$$

أما القسم الدراسي فقد تضمن فصلين:

الفصل الأول: ابن تيمية حياته، وعصره، وفيه مبحثان:

المبحث الأول: عصره، وفيه ثلاثة مطالب:

المطلب الأول: الحالة السياسية

المطلب الثاني: الحالة الاجتماعية

المطلب الثالث: الحالة العلمية

المبحث الثاني: حياته، وفيه ستة مطالب:

المطلب الأول: اسمه، و كنيته، ونسبه

المطلب الثاني: مولده وونشأته

المطلب الثالث: شيوخه، و تلاميذه

المطلب الرابع: منــــلته العلمية، وآثاره

المطلب الخامس: مذهبه، وعقيدته

المطلب السادس: و وفاته

الفصل الثاني: كتاب العبودية، وفيه سبعة مباحث:

المبحث الأول: توثيق نسبة الكتاب إلى مؤلفه

المبحث الثاني: تحقيق عنوان الكتاب

المبحث الثالث: تاريخ تأليف الكتاب و سببه

$-I \vee \Lambda_{-}$ 


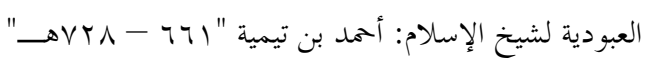

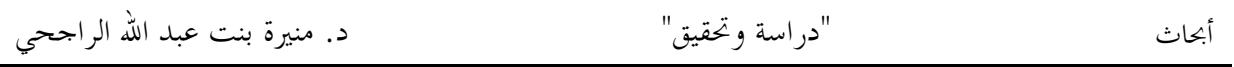

المبحث الرابع: محتويات الكتاب، و كيفية عرض المؤلف لها المبحث الخامس: منهج المؤلف في الكتاب المبحث السادس: مصادر الكتاب

المبحث السابع: وصف نسخ الكتاب، وعرض نماذج منها. ** * 


\section{القسهر التحقيقي}

فيشتمل على تحقيق النص وتوثيقه، والتعليق على ما يحتاج إلى تعليق. ولتحقيق ذلك اتبعت الخطو ات الآتية:

أولا: وصف نسخ المخطوط:

سعيت في جمع نسخ الكتاب فتبين لي بعد التقصي والتتبع أن له عددا من النسخ، تحل لدي منها نسختان مخطوطتان، وأحاول جاهدة الحصول على بقية النسخ أو بن

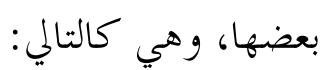

1- نسخة مكتبة الجامعة الإسلامية، وهي مصورة من جامعة ليدن بهولندة، حفوظة برقم (乏)

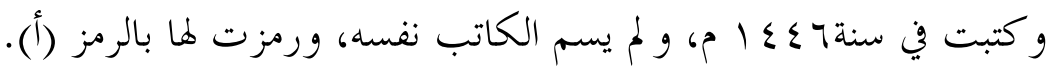

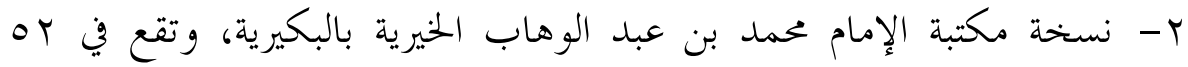
صفحة، عدد الأسطر من \| - ع ؟، و الناسخ سليمان بن سحمان ن ورمزت لها

$$
\text { بالرمز (ب). }
$$

r- نسخة بحموع الفتاوى جمع وترتيب بن قاسم وتقع في 1 ب صفحة، ورمزت لها بالرمز (ج).إلا إذا حصلت على النسخة التي تم اعتماد جامع الفتاوى عليها، وإنما اعتمدها تحسبا أن يكون قد اعتمد على نسخة لم إد تصل إليها يدي. أما بقية النسخ المخطوط و التي لم أقف عليها حتى الآن فهي كالتالي: أ- له أربع نسخ في المكتبة السليمانية بتر كيا هي: 
ع - في خزانة أزميرلي إسماعيل رقم (بrTr) في rY ورقة

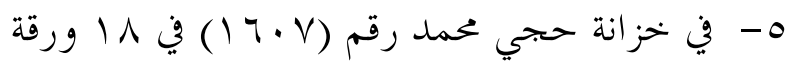

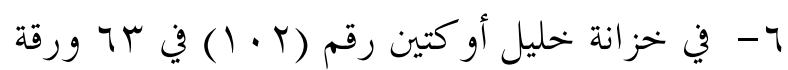

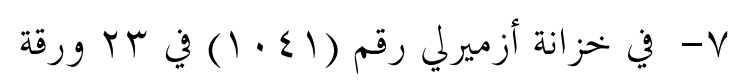

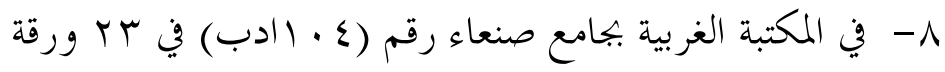
9- في جامعة ليدن هولندة رقم (Yq) في r ب و ورقة

ثانيا: منهجي في التحقيق:

سأعمل على إخراج الكتاب بصورة علمية دقيقة حسب الاستطاعة، ولتحقيق ذلك سوف أسلك الخطو ات الآتية بعون الله:

أ- سأعتمد النسخة الأولى المصورة من مكتبة الجامعة الإسلامية وأجعلها أصلا للتحقيق؛ وذلك لكوها أصح وأكمل وأقدم النسخ المتوفرة لدي حتى الآن، وذلك ما ولكا

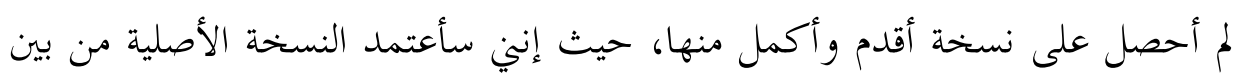
النسخ الخطية التي ستتوفر لي وأجعلها أصلا للتحقيق. ب-بعد نسخ الكتاب من نسخة الأصل أقوم بإثبات ما في الأصل على حاله ولا

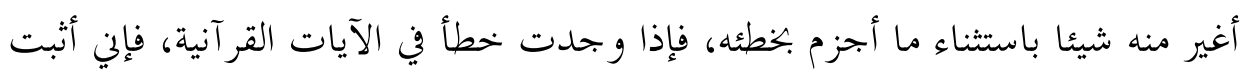

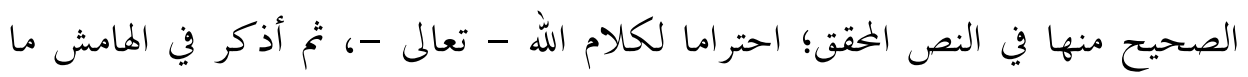
ورد في الأصل محرفا، بعد التأكد التام من أنه ليس قراءة صحيحة.

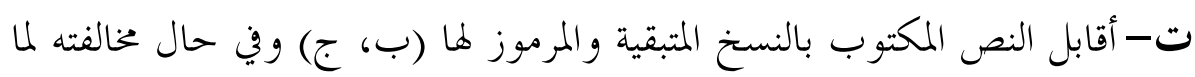
في الأصل أثبت في الصلب ما في الأصل ولا أعدل عنه إلا إذا جزمت بخطئه فإين أثبت 
الصواب في الصلب بين قوسين من بقية النسخ وأذكر في الهامش أن الأصل فيه كذا وهو خطأ، وإذا حصل في إحدى النسخ أو في جميعها سقط أو نقص عما في الأصل أشير إلى ذلك في الهامش، فإن كان كلمة أو نحوها أعدت ذكره في الهامش، وإلا قلت: من قوله: كذا إلى قوله: كذا سقط من نسخة كذا، وإذا وُجد فيها أو في إحداها زيادة على ما في الأصل، فإن كان النص لا يستقيم بدوها أثتتها في الصلب وأشرت إلى ذلك في الهامش، وإن كان يستقيم بدوها ذكرت الزيادة ومصدرها في الهامش أيضا. ث- إذا وجد في هامش نسخة الأصل تعليق لاستدراك ما سقط من النص سهواً وألحق تصحيحا، فإني أثبته في مكانه من النص ذاكرة ذلك في الهامش، مشيرة إلى أنه ملحق بهامش الأصل. وإن كان التعليق من بقية النسخ - و لم يكن في نسخة الأصل - ذكرته في الهامش لد و بينت مصدره.

ثالثاً: ما يتعلق بكتابة النص، أتبع ما يأتي: أ- رسم الكتابة بالرسم المعاصر، مراعية القواعد الإملائية الحلديثة، ووضع الفو اصل والنقط، وعلامات التنصيص، وبدايات الأسطر ووضع الجمل الاعتراضية داخل شرطتين هكذا - - -، حتى يتحقق ربط أجزاء الكلام بعضه ببعض، إلا في النص القرآي فإني أكتبه بالرسم العثماني كما هو في المصحف. ب- ضبط الألفاظ التي يقع في قراءها لبس بالشكل، و كذلك الألفاظ والأعلام التي يقع في قراءةا لبس. 


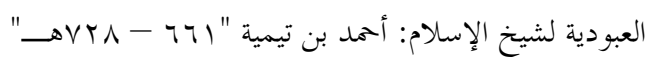

د. منيرة بنت عبد الله الراجحي

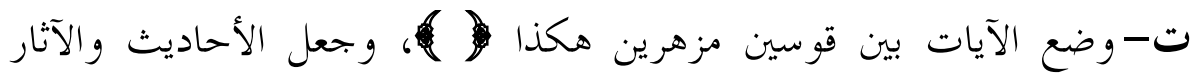

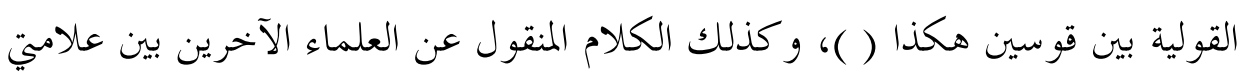

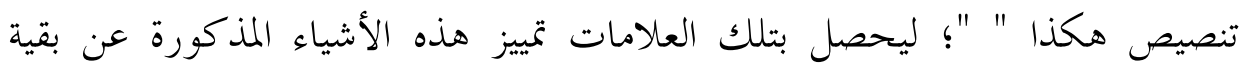
النص. - n

ث- وضع عناوين لمسائل الكتاب مستمدة ذلك من كلام المؤلف نفسه.

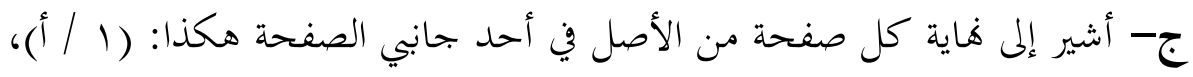

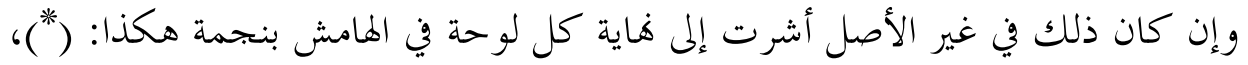

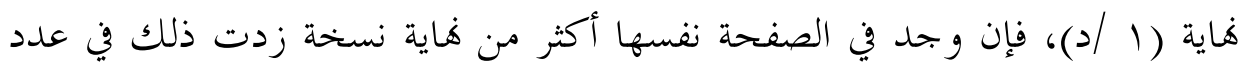

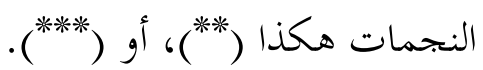
رابعا: عزو الآيات إلى مواضعها في كتاب الله - تعالى - مشيرة في المتن إلى اسم

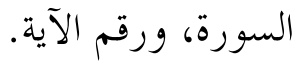
خامسا: تخريج الأحاديث والآثار من مصادرها الأصلية، وإذا ورد الحديث في الحادئ

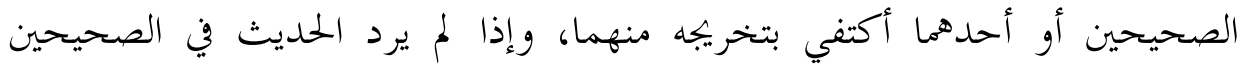

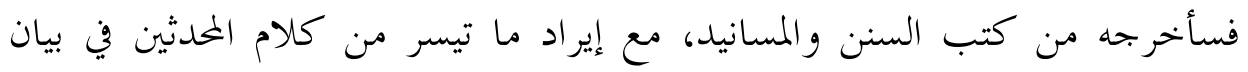

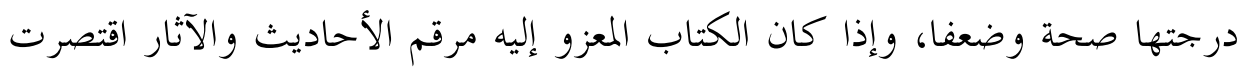

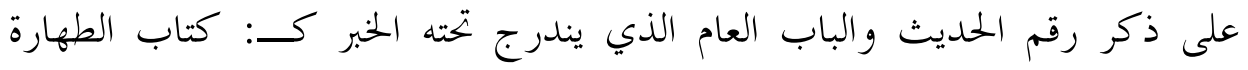

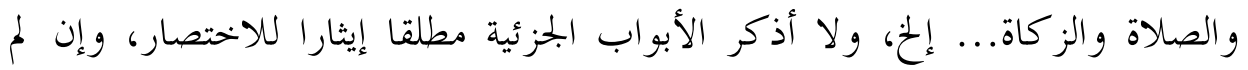

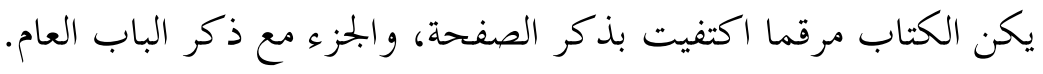

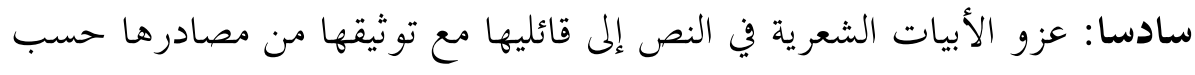

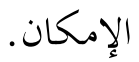


سابعا: ترجمة الأعلام الذين ورد ذكرهم في النص بترجمة موجزة، باستثناء الأنبياء

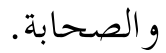

ثامنا: مقابلة النصوص المقتبسة في النص على مصادرها، مع توثيقها، فإن لم أجد المصدر المنقول منه وثقتها بواسطة بعض المصادر التي أفاد منها المؤلف إن وجدت. تاسعا: أحيل في غالب المسائل التي تناولها المؤلف إلى بعض الكتب التي بحثت تلك

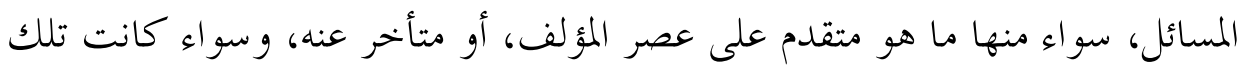
المسائل عقدية أو فقهية أو لغوية، أو منطقية، أو غيرها. عاشرا: أعلق على النص بذكر ما يستدعيه المقام من إيضاح لفظ غريب، أو تفسير

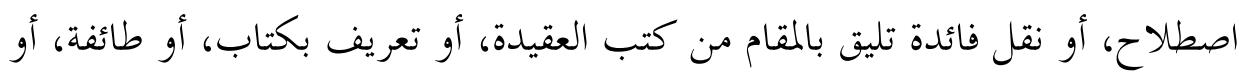
مكان....

حادي عشر: ربط مباحث الكتاب بعضها ببعض، وذلك بتعيين موضع الإحالات التي يذكرها المؤلف بقوله: "سيأتي ذكر كذا وكذا" أو "مر ذكر كذا". ثالي عشر: إذا كانت عبارة الكتاب محتملة لعدة معان أنقل ما يوضح ذلك من كتبه الأخرى التي أقف عليها، أو أشير إلى موضعه ولا سيما إن كان لهذا الاختلاف أثر ظاهر.

ثالث عشر: وضع فهارس تسهل الإفادة من الكتاب، وتشتمل على الآتي:

$$
\begin{aligned}
& \text { ا - فهرس الآيات } \\
& \text { ץ- فهرس الأحاديث النبوية } \\
& \text { r- فهرس الآثار }
\end{aligned}
$$




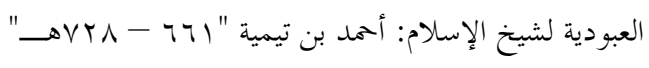

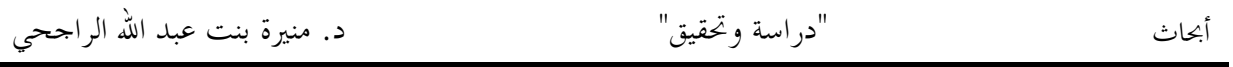

$$
\begin{aligned}
& \text { ع - فهرس الطو ائف و الفرق } \\
& \text { ه- فهرس الأشعار والأمثال } \\
& \text { 7- فهرس الأماكن و البلدان } \\
& \text { - فهرس الأعلام }
\end{aligned}
$$

1- أذكر في هاية التحقيق ثبتا بالمصادر والمراجع التي رجعت إليها في تحقيق

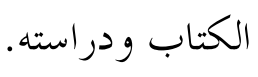

$$
\text { 9- فهرس الموضوعات (المختوى). }
$$




\section{القسهر التحقيقي}

\section{حقيقن العبوديت}

(1)

بسم الله الرحمن الرحيم

سئل الشيخ الإمام العلامة محيي السنة ومميت البدعة أبو العباس أحمد بن تيمية -

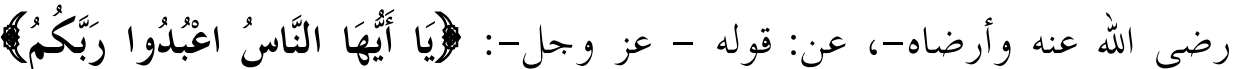

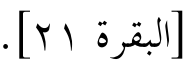

فما العبادة وفروعها؟ وهل بحموع الدين داخل في العبادة (r) أم لا؟ وما (r) حقيقة العبودية؟ وهل هي أعلى المقامات [في الدنيا والآخرة] (؛) أم فوقها شيء من

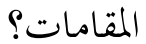

وليبسط (o) لنا القول في ذلك (T) : فأجاب ن

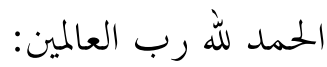

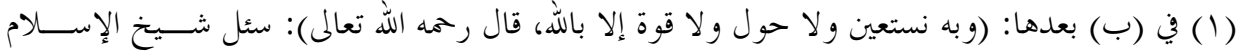

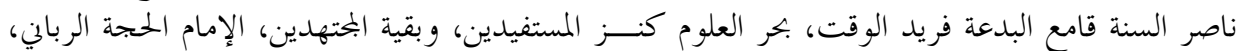

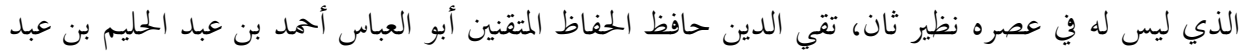

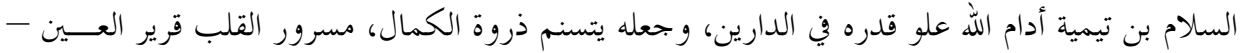

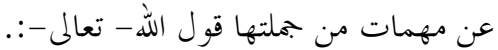

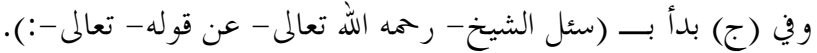
(Y) (ب) في (ج) و(ج): "فيها" (ب) بدل (العبارة).

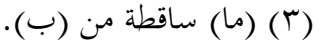
(ع) (في الدنيا والآخرة) ساقطة من (أ) و المثبت من (ب) و(ج). (0) في (ج) "وليبسطوا". (7) في (ب) "مأجورين إن شاء الله". 
العبادة هي:(') اسم جامع لكل ما(r) يجبه الله ويرضاه من الأقوال والأعمال الباطنة

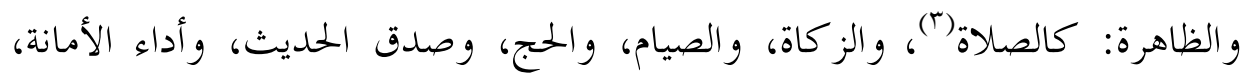

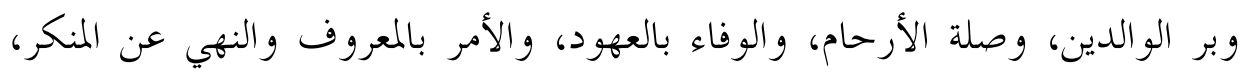

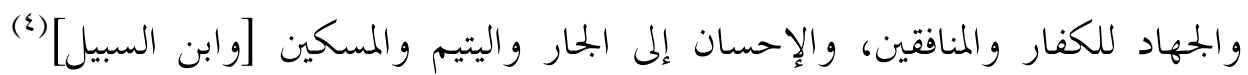
و المملوك من الآدميين والبهائم، والدعاء، والذكر، و القراءة، وأمثال ذلك من العبادة.

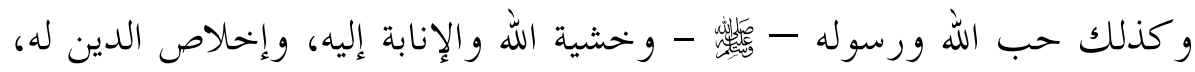
و الصبر للحممه والشكر لنعمه، و الرضا بقضائه، و التوكل عليه، و الرجاء لرحمته،

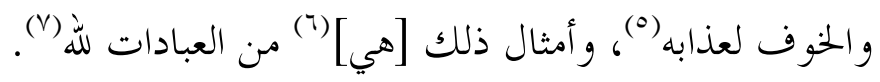

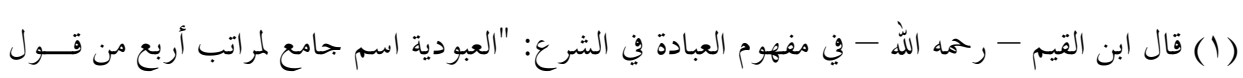

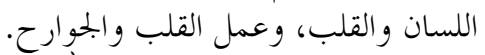

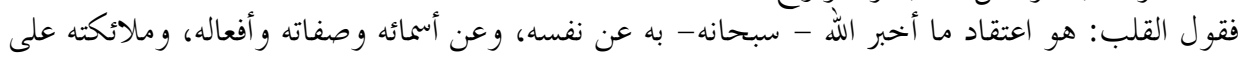

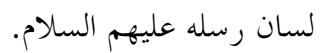
وقول اللسان: الإخبار عن قول القلب بلبه بما فيه من الاعتقاد، والدعوة إليه، والذب عنه، وتبيين بطلان البدع المخالفة، والقيام بذكره وتبليغ أوامره.

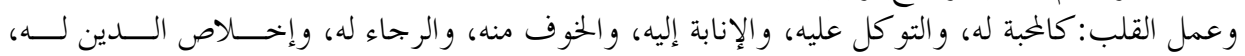

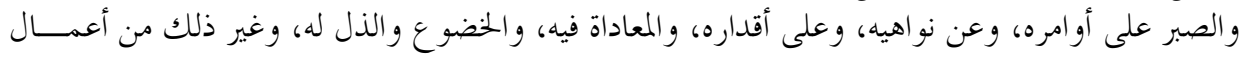
القلب.

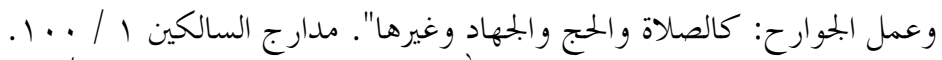

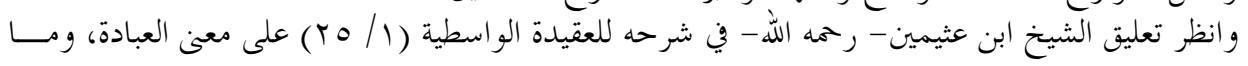
الذي تطلق عليه. (r)

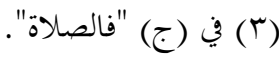

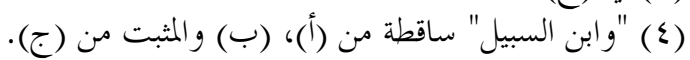

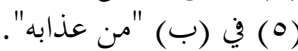

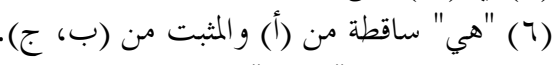

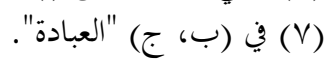


وذلك أن العبادة لله هي الغاية المحبوبة لله (1)، والمرضية له، التي خلق الخلق ها كما

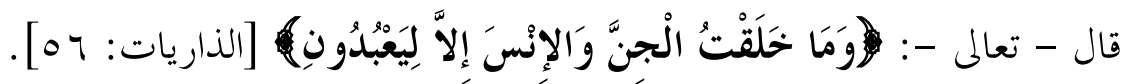

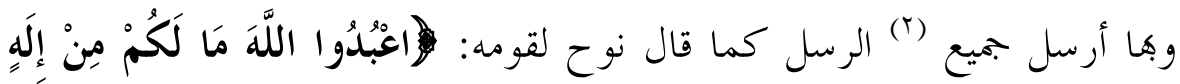

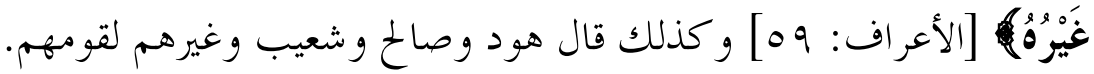

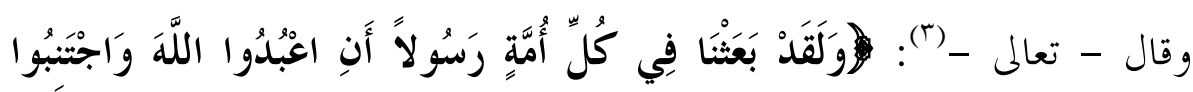

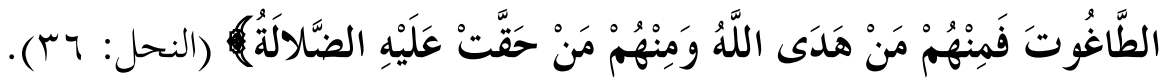

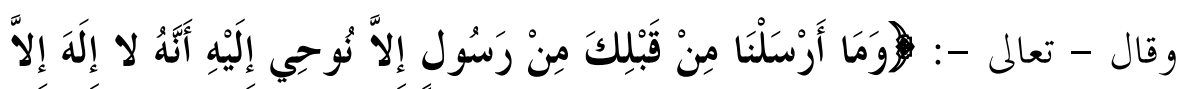

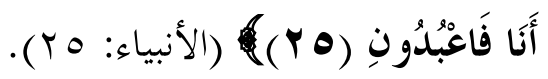

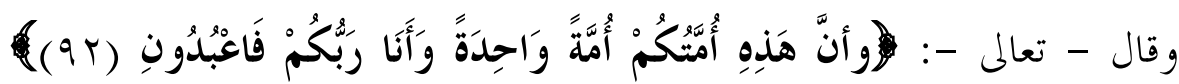

$$
\text { (الأنبياء و و ( })
$$

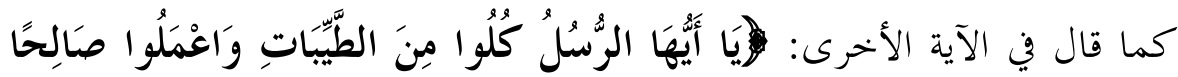

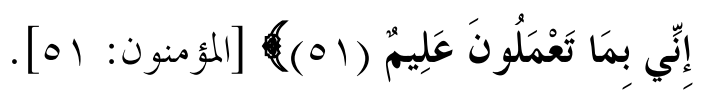

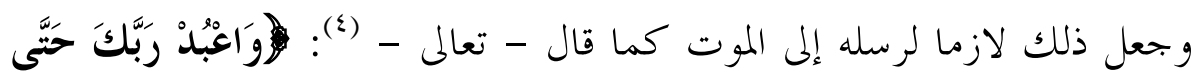

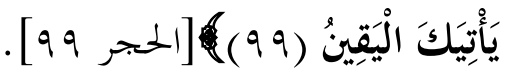

$$
\begin{aligned}
& \text { *هاية (1 / ب) بته) }
\end{aligned}
$$

$$
\begin{aligned}
& \text { (1) في (ج) "له". }
\end{aligned}
$$

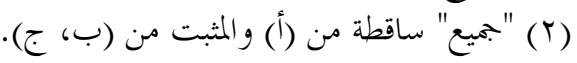

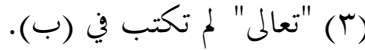

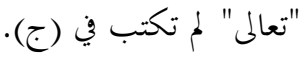


وبذلك وصف ملائكته وأنبياهه (1) فقال - تعالى -: الوَوَلَهُ مَنْ فِي السَّمَاوَاتِ

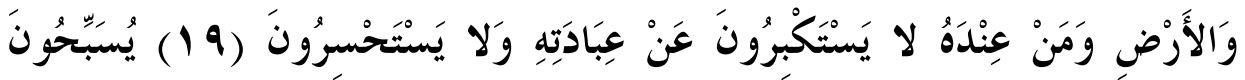

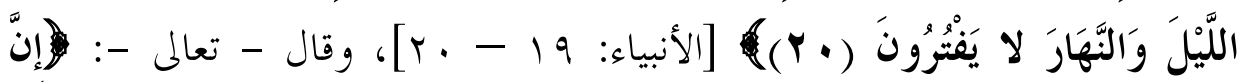

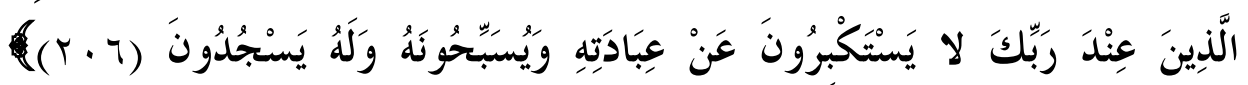

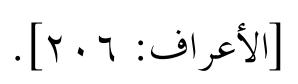

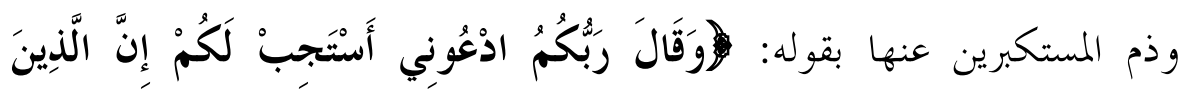

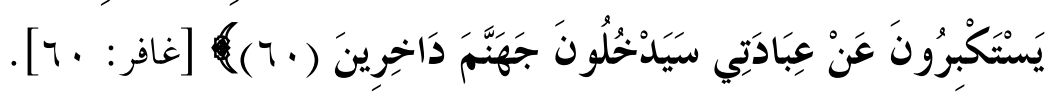

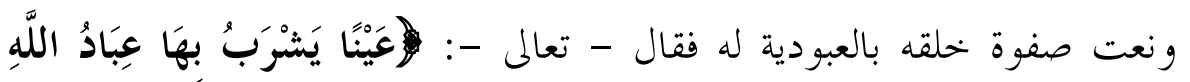

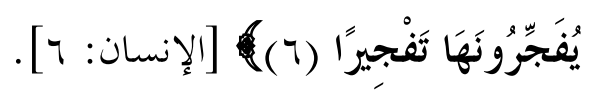

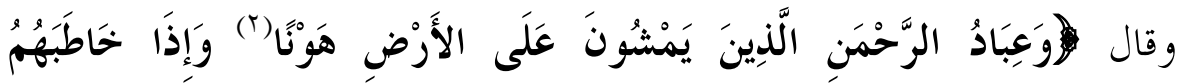

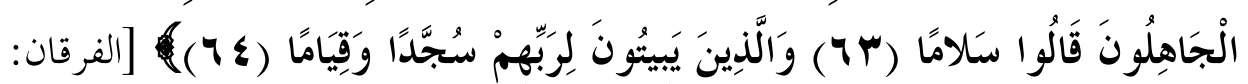

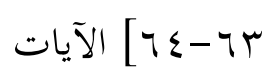

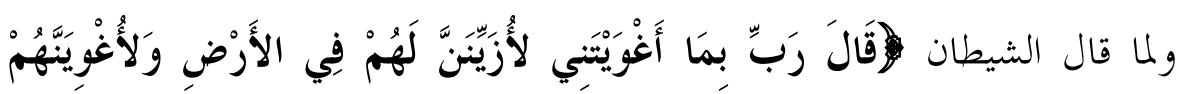

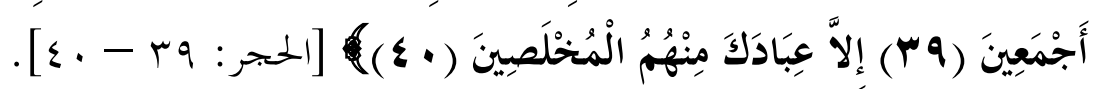

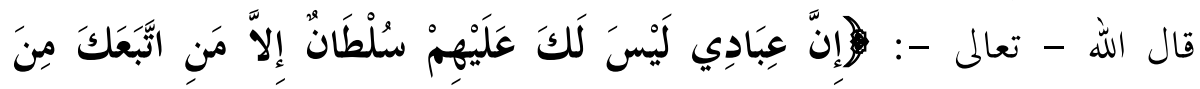

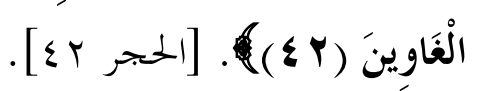

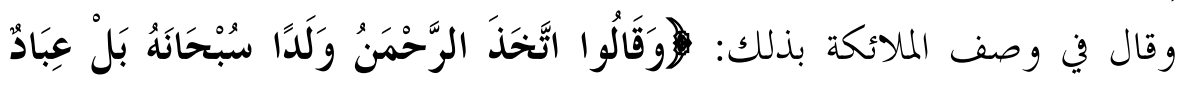

$$
\begin{aligned}
& \text { (1) "و بذلك وصف ملائكته وأنبياءه. ساقطة من (ب). } \\
& \text { (T) في (ج) كتب الآية إلى "هونا" و ولم يكملها. } \\
& -119
\end{aligned}
$$




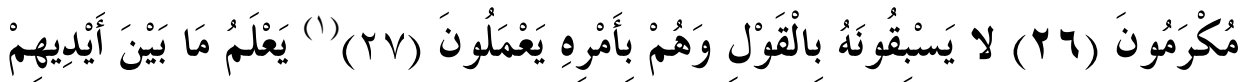

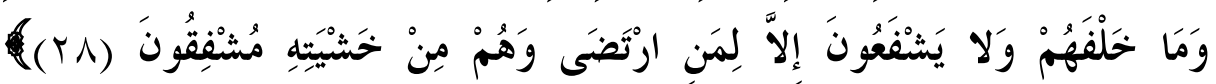

$$
\text { [الأنبياء: بr }
$$

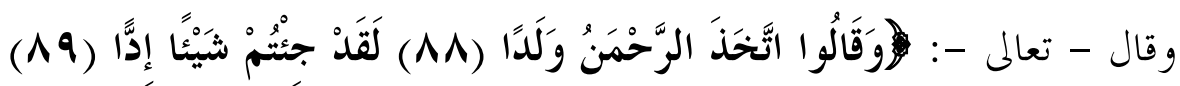

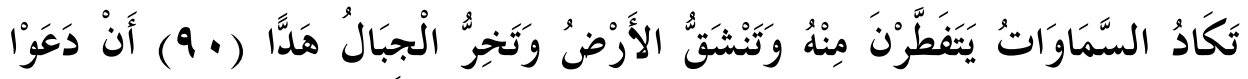

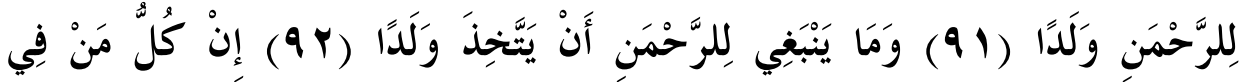

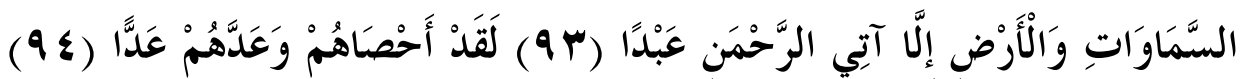

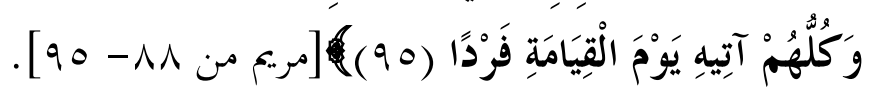

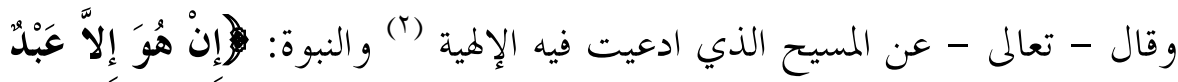

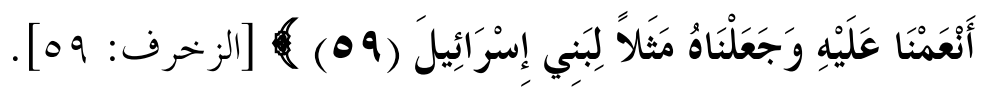

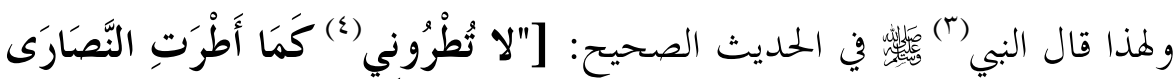

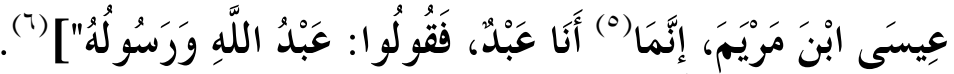

$$
\begin{aligned}
& \text { (1) في (ج) قال بعدها: إلى قوله: (وَهُمْ مِنْ خَشْيَتِهِ مُشْفْقِقُنَ). } \\
& \text { (r) في (ب) "الألوهية". }
\end{aligned}
$$

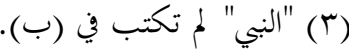

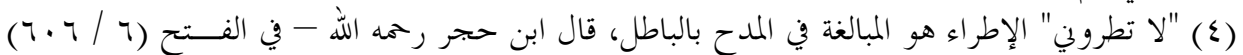

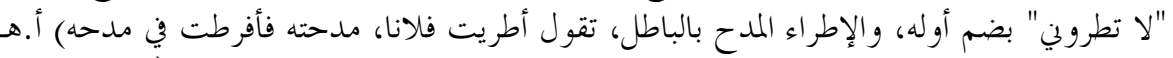

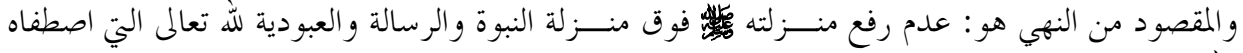

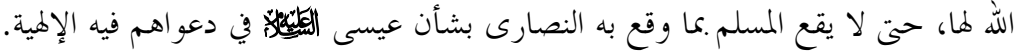

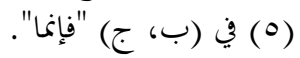

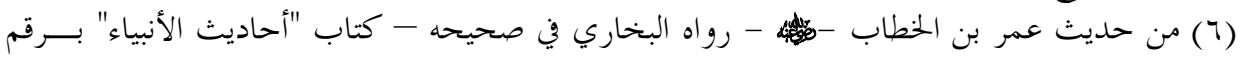


وقد نعته الله بالعبودية في أكمل أحو اله فقال في الإسراء: الِسبْحَانَ الَّذِي أَسْرَى

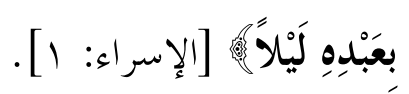

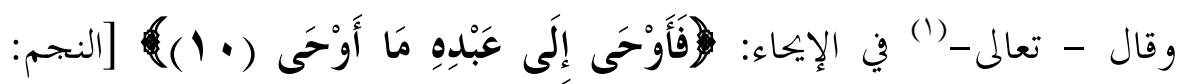

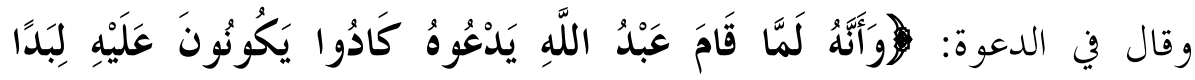

$$
\text { [1 } 19 \text { : } 19 \text { : } 19 \text { (19) }
$$

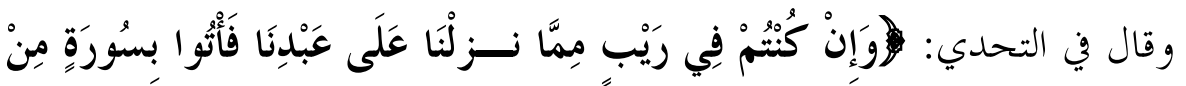

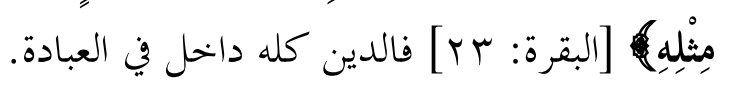

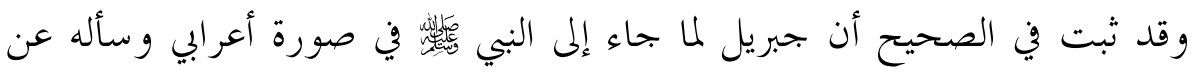

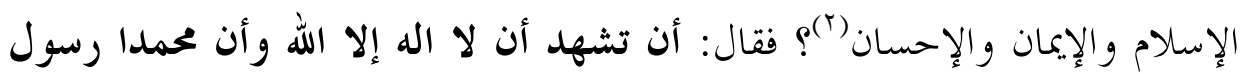
الله، وتقيم الصلاة، وتؤتى الز كاة، وتصوم رمضان، وتحج البيت إن استطعت إليه سبيلا. قال: فما الإيمان؟ قال: أن تؤمن بالله، وملائكته، وكتبه، ورسله، والبعث بعد الموت، وتؤمن بالقدر خيره وشره، قال: فما الإحسان؟ قال: أن تعبد الله كأنك تراه فإن لم تكن تراه فإنه يراك). تخم قال في آخر الحديث: (هذا جبريل جاءكم

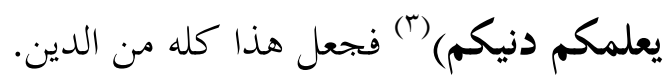

$$
\begin{aligned}
& \text { (1) "تعالى" ساقطة من (أ، ج) و المثبت من (ب). }
\end{aligned}
$$

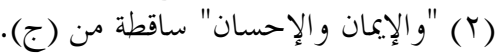

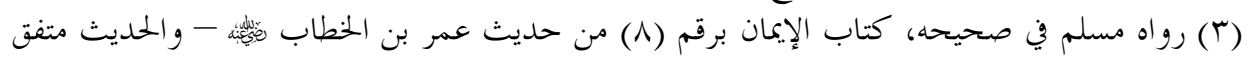

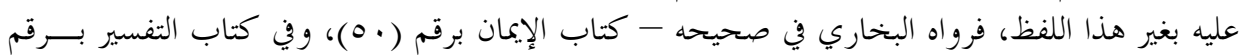

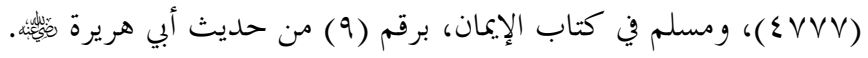


والدين يتضمن معنى الخضوع والذل يقال: دنت فلانا. أي: أذلته فذل، ويقال:

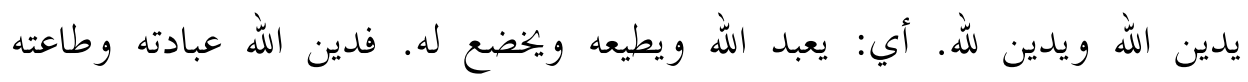
والخضوع له.

والعبادة أصل معناها: الذل أيضا. يقال: طريق معبد إذا كان مذلا قد وطئته

$$
\text { الأقدام (1). (1 / أ) }
$$

لكن العبادة المأمور هـا تتضمن معنى الذل ومعنى الحب فهي تتضمن غاية الذل لله

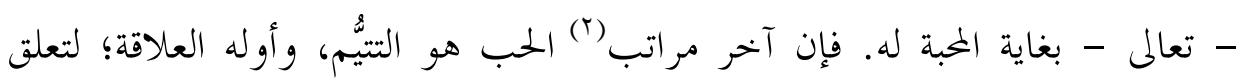

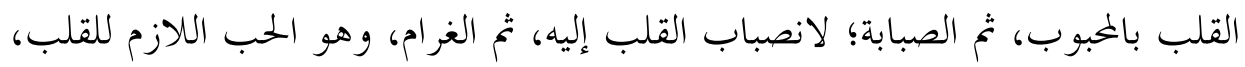

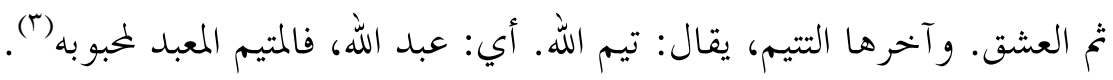

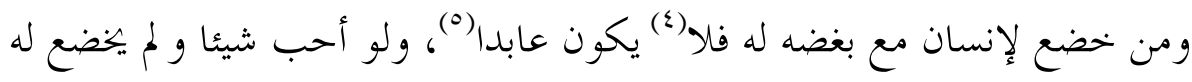

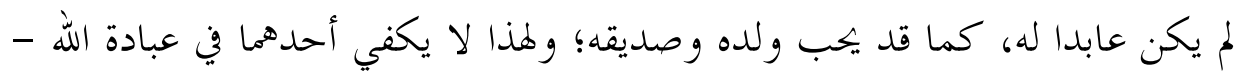

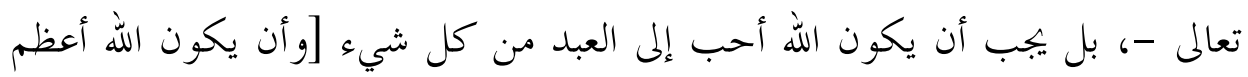

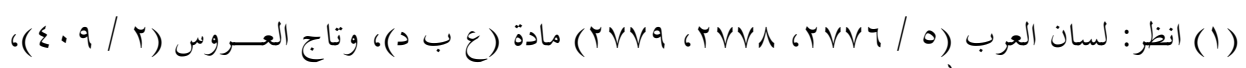

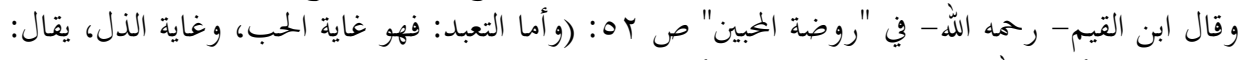

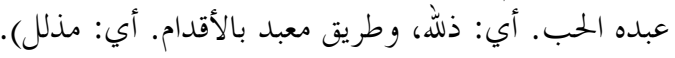

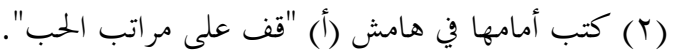

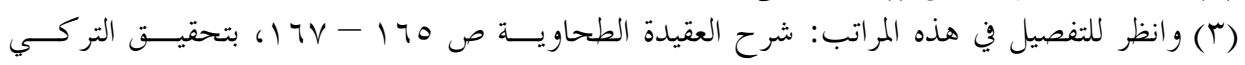

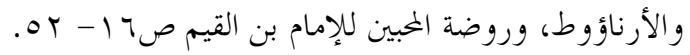

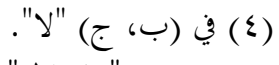

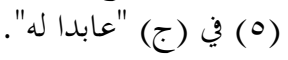


عنده من كل شيء] (1) بل لا يستحق المحبة والذل التام إلا الله.

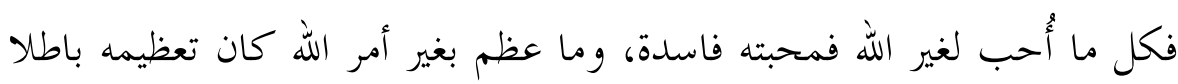

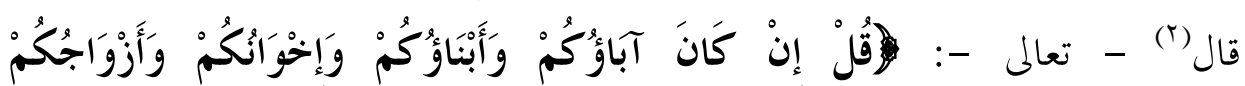

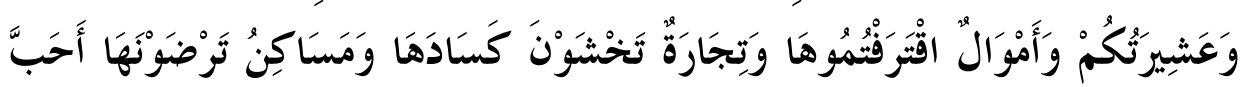

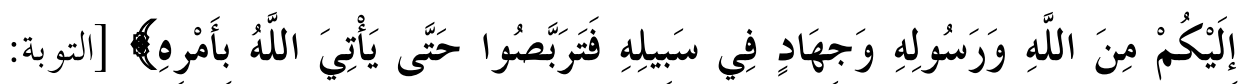

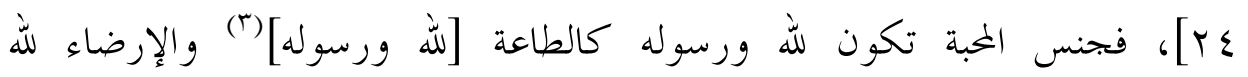

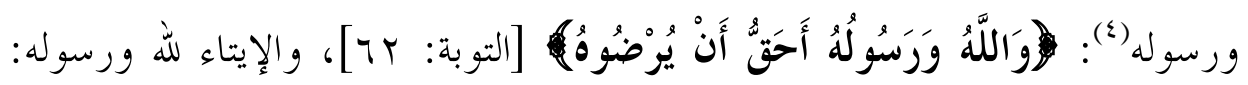

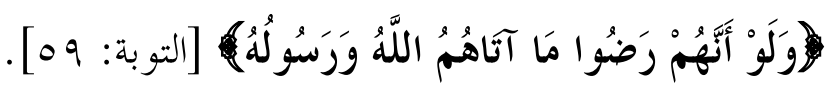

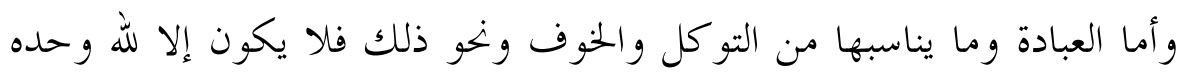

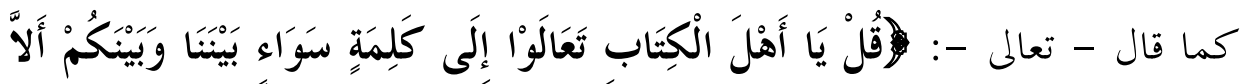

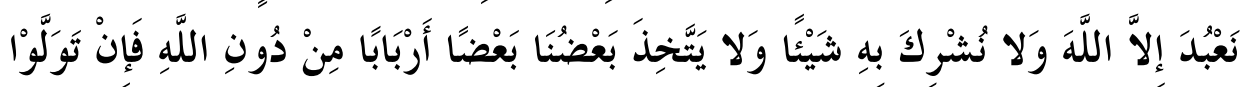

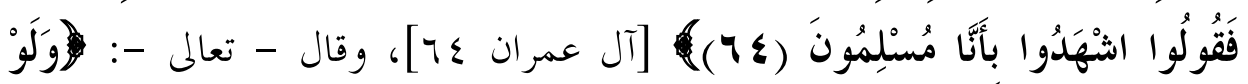

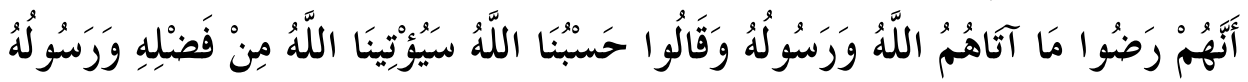

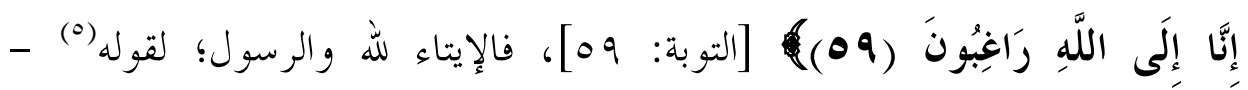

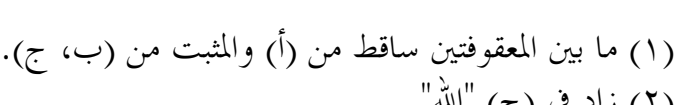

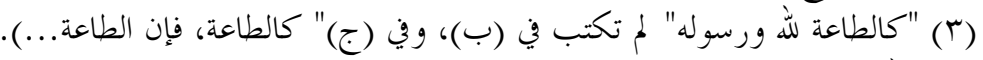

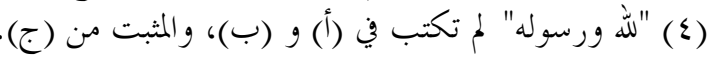

$-194$ 


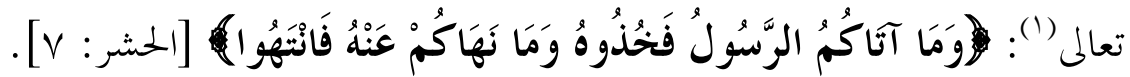

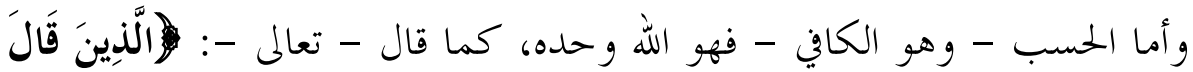

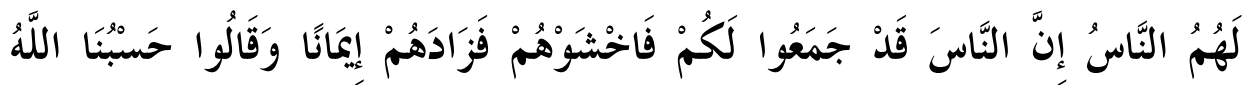

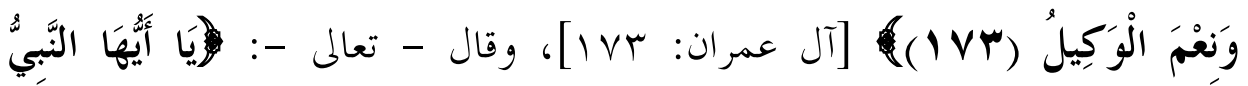

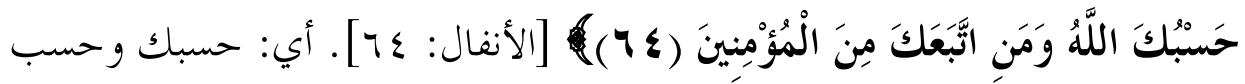

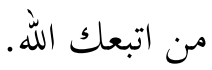

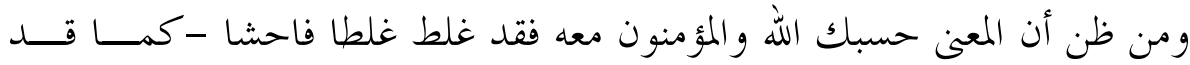
بسطناه في غير هذا الموضع (؟).

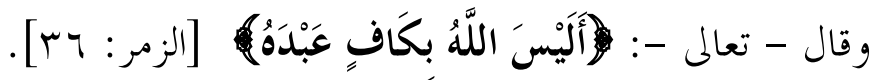
تحرير ذلك: أن العبد يراد به المعبد الذي عبده الله فذلّله ودبره وصرفه.

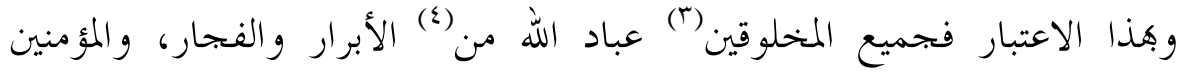

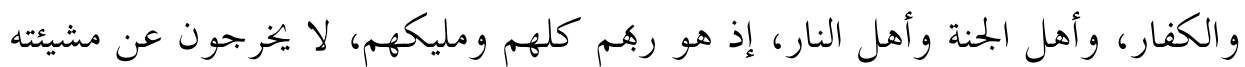

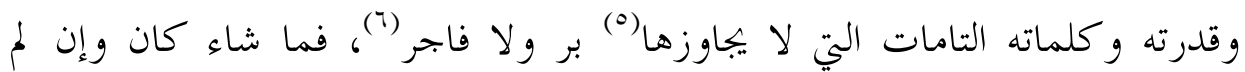

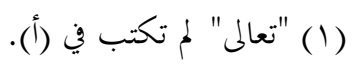

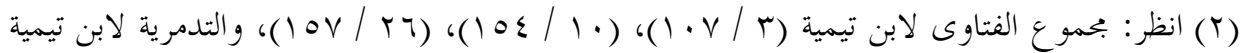

$$
\begin{aligned}
& \text { ص ا .T، وغيرها من المواضع. } \\
& \text { (ب) في (ج) "المخلوقون كلهم". }
\end{aligned}
$$

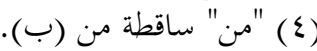

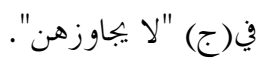

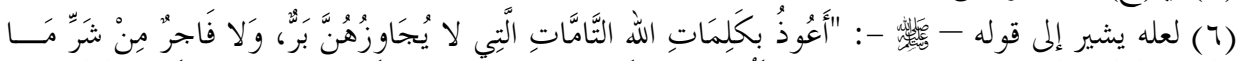

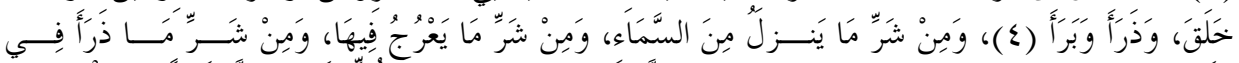

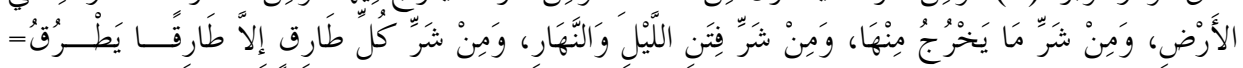




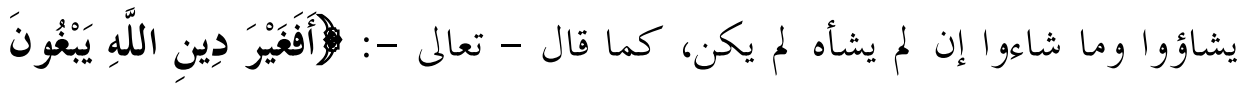

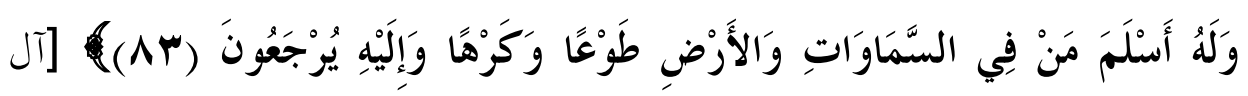

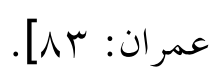

فهو - سبحانه- رب العالمين وخالقهم ورازقهم ومحييهم ومميتهم ومقلب قلوبمم

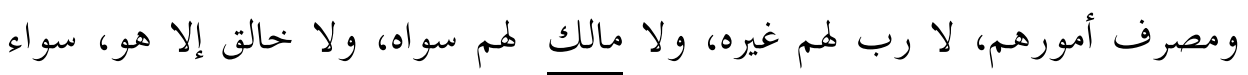

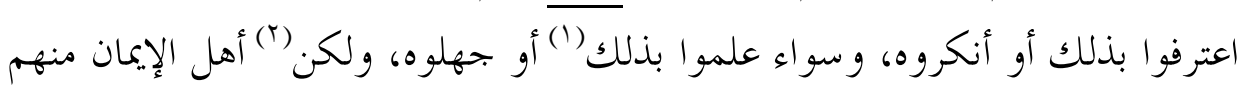

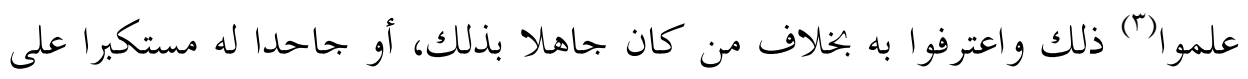

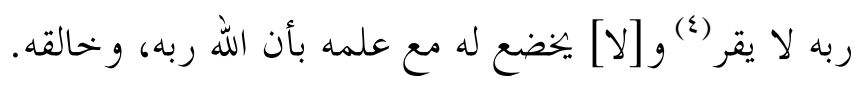

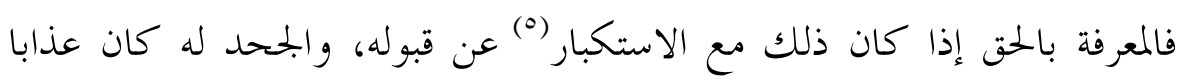

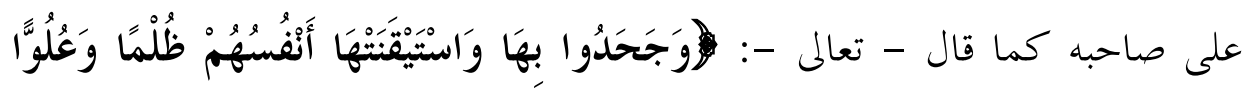

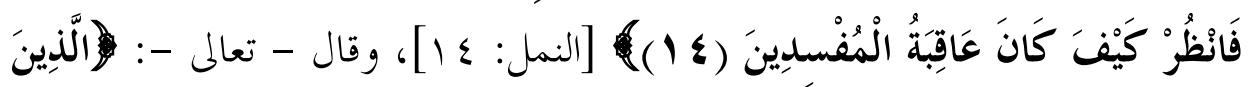

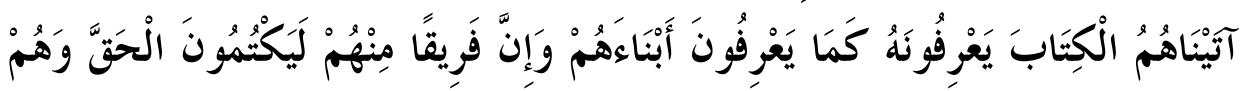

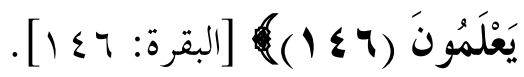

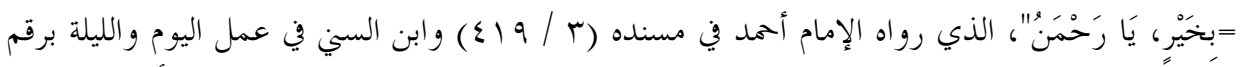

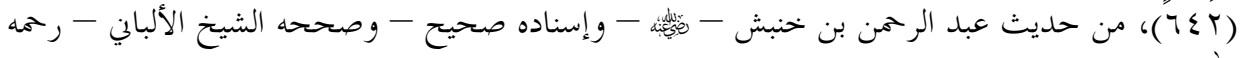

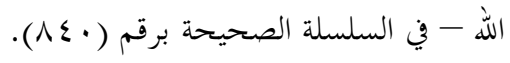

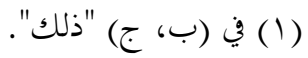
(Y)

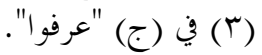

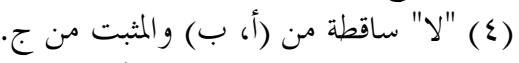

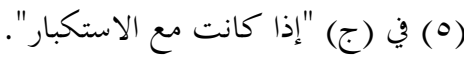




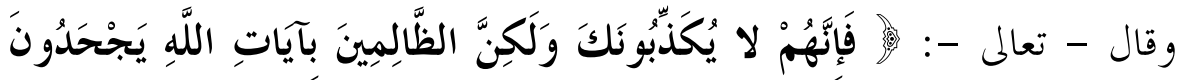

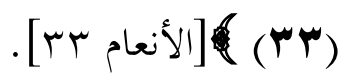

فإذا عرف (1) العبد أن الله ربه وخالقه، وأنه مغتقر إليه، ومحتاج(r) إليه عرف عبوديته (") المتعلقة بربو بية الله. وهذا العبد يسأل ربه ويتضرع له (i) ويتو كل عليه، لكن قد يطيع أمره وقد يعصيه، الهاه وقد يعبده مع ذلك، وقد يعبد الشيطان والأصنام.

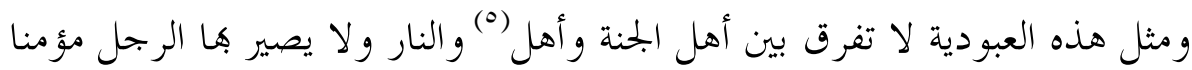

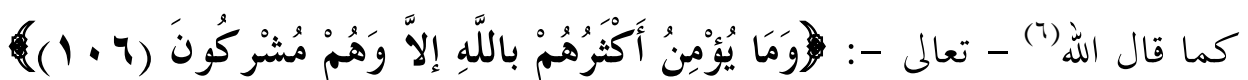

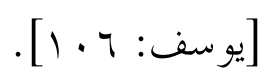

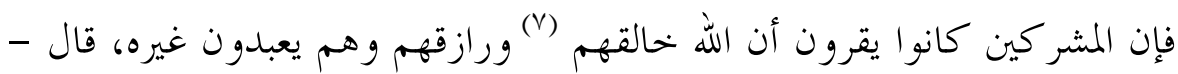

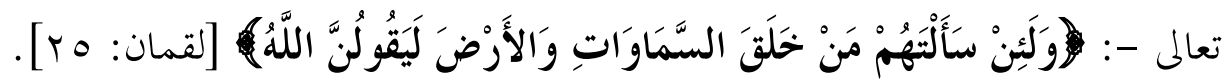

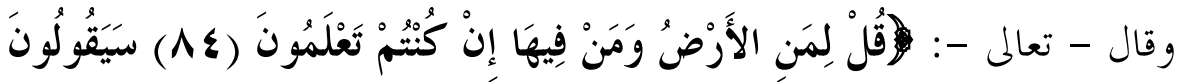

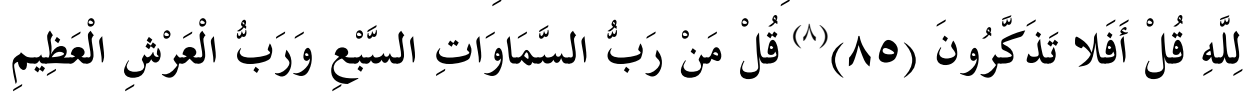

$$
\begin{aligned}
& \text { (1) في (ج) "فإن اعترف". }
\end{aligned}
$$

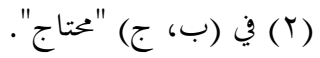

$$
\begin{aligned}
& \text { (צ) } \\
& \text { (ع) "مي (ج) "فيتضرع إليه". }
\end{aligned}
$$

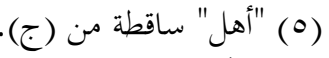

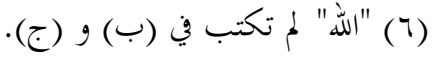

$$
\begin{aligned}
& \text { (ج) زاد في (ج) "ورازقهم". }
\end{aligned}
$$$$
\text { (^) في (ج) كتب بعدها إلى قوله: "قل فأنى تسحرون". }
$$ 


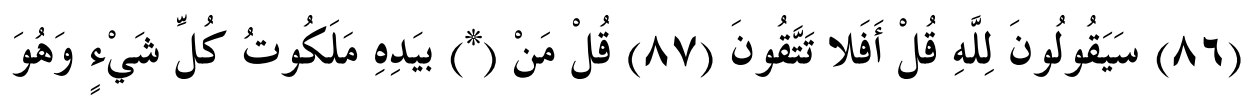

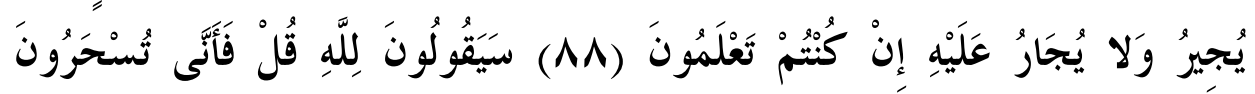

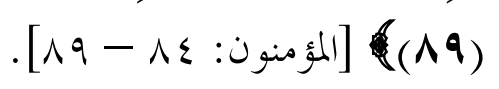

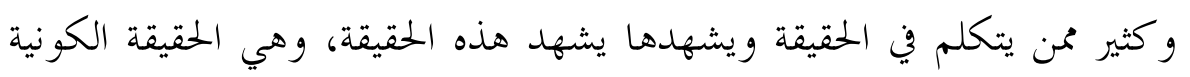

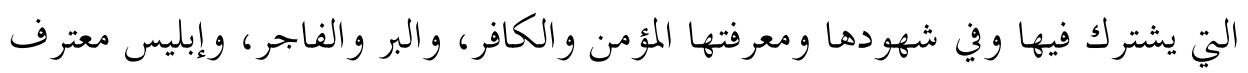

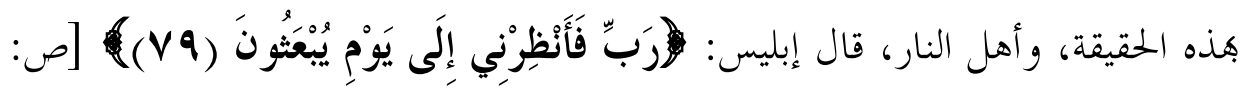

. [va

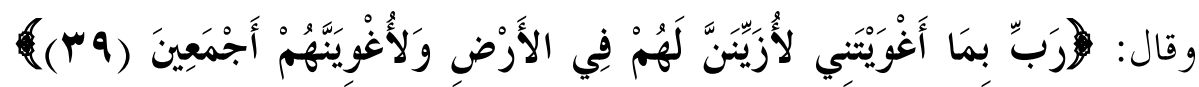

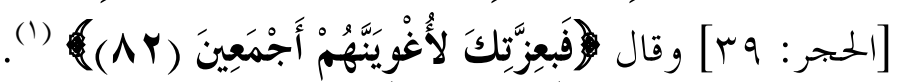

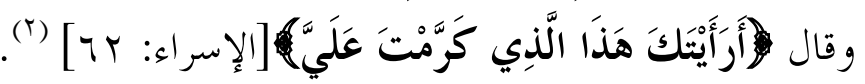

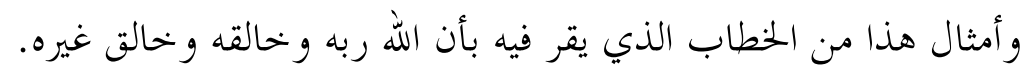

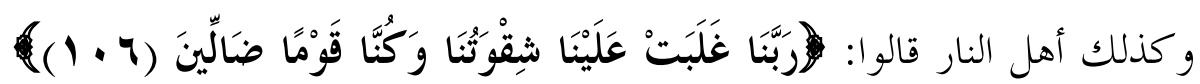

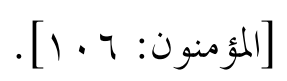

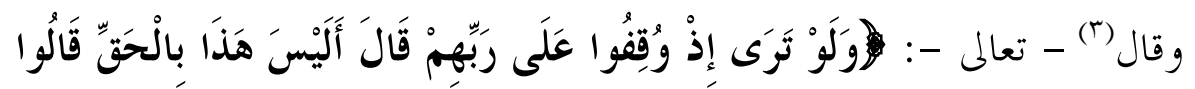

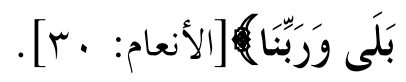

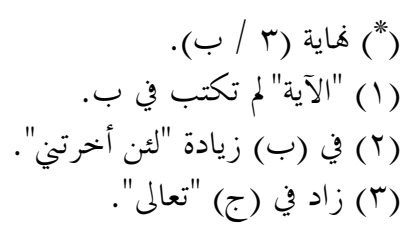

$-19 V$. 
فمن وقف عند هذه الحقيقة (وعند شهودها و لم يقم بما أمر به من الحقيقة)(1)

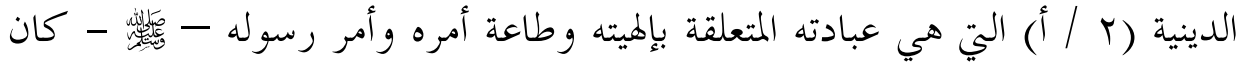

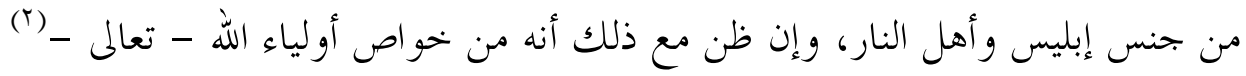
وأهل المعرفة و التحقيق الذين سقط (ّ) عنهم الأمر و النهي الشرعيان(() كان من أشر(0) أهل الكفر والإلحاد (T) وون ظن أن "الخضر" أو غيره(V) سقط عنهم الأمر(^) لمشاهدة الإرادة ونحو ذلك كان قوله هذا من شر أقوال الكافرين بالله ورسله(9) حتى يدخل في النوع الثاني من معنى العبد، و هو العبد بكعنى العابد(·) فيكون عابدا لله لا يعبد إلا إياه فيطيع أمره (1)

$$
\begin{aligned}
& \text { (1) من قوله: "وعند شهودها..." إلى هنا ساقط من (ب). }
\end{aligned}
$$

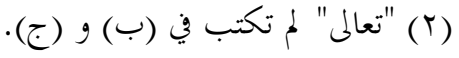

$$
\begin{aligned}
& \text { (Y) }
\end{aligned}
$$

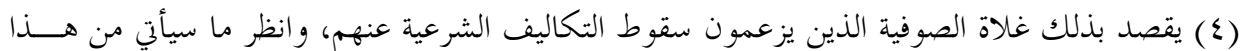

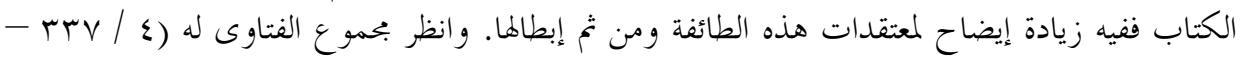
(ب) .

(7) أصل الإلحاد في كلام العرب: العب العدول عن القصد، والميل عن الشيء، والجور و الاخحراف، ومنه اللحد

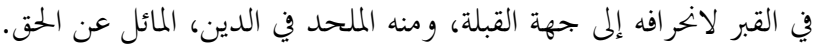

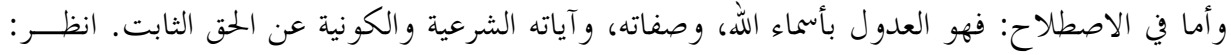

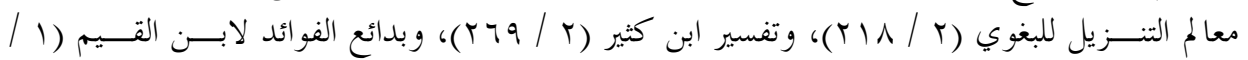

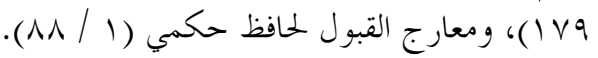

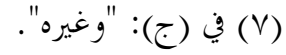

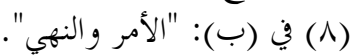
(ج) في (ج): "ورسوله".

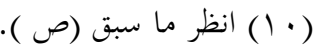
(111) في (ب): "أمر الله". 


$$
\text { و أمر رسوله (1) ويو الي أولياءه المؤمنين المتقين ويعادي أعداءه. }
$$

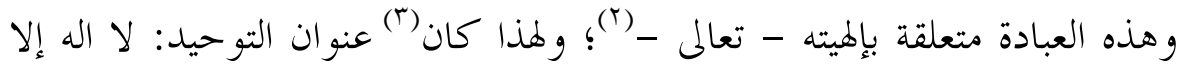
الله بخلاف من يقر بربوبيته(ع) ولا يعبده أو(0) يعبد معه إلها آخر. فالإله الذي يألهه

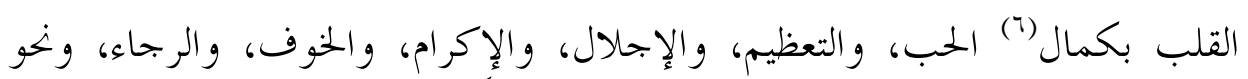
ذلك. وهذه العبادة هي العبادة الَّي يُحبها الله (V) ويرضاها، وهـا وصف المصـــفين مــن عباده و وها بعث رسله. وأما العبد بمعنى المعبّد سواء أقرّ بذلك أَو أنكره فهذا المعنى يشترك فيـــهـ الْمـــؤمن و الكافر. وبالفرق بين هذين (^) النوعين يعرف الْفرق بين "الحقائق الدينية" الدّاخلة في عبادة

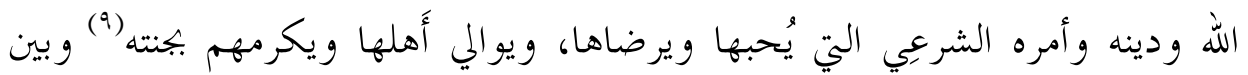

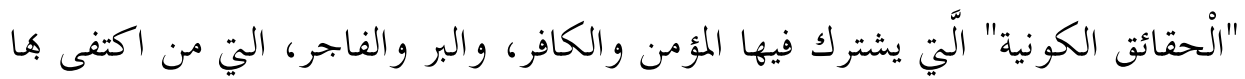

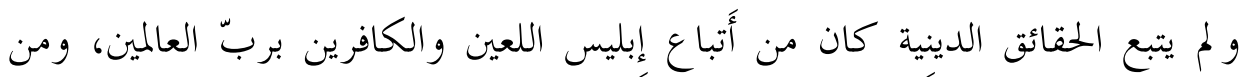

$$
\begin{aligned}
& \text { (1) (ب) (ج): "رسله". } \\
& \text { (ب) في (ب): "بإلهية الله تعالى". }
\end{aligned}
$$

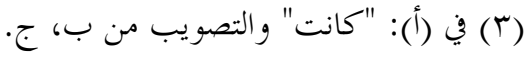

$$
\begin{aligned}
& \text { (ع) في (ب): "بعبوديته". }
\end{aligned}
$$

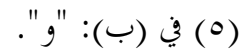

$$
\begin{aligned}
& \text { (َ) في (ب): "فكمال". }
\end{aligned}
$$

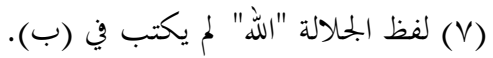

$$
\begin{aligned}
& \text { ) (૧) في (ب): "هذه". } \\
& \text { (9) في (أ): "يحسبه" و التصويب من (ب، ج). }
\end{aligned}
$$


اكتفى بها فِي بعض الأمور دون بعض أَو في مقام أَو حال نقص من إيمانه وولايته لله بحسب ما نقص من الحقائق الدينية. وهذا مقام عظيم فيه غلط الغالطون، و كثر فيه الاشتباه على السالكين، حتى زلق

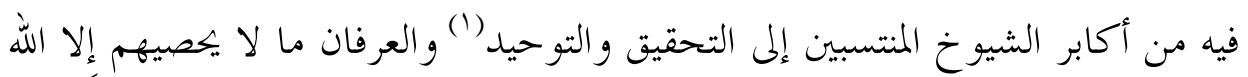
الذي يعلم السرّ و الإعلان.

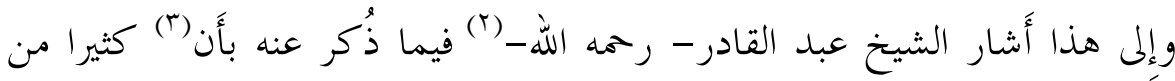

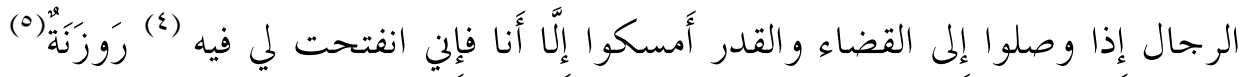

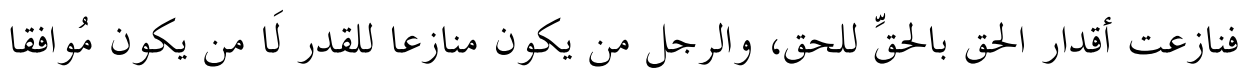
للقدر (7) والذي ذكره الشيخ- رحمه الله- هو الذي أَمر الله به ورسوله(V)، لكن كثيراً من

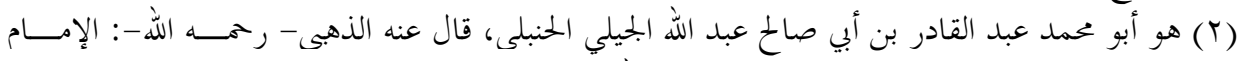

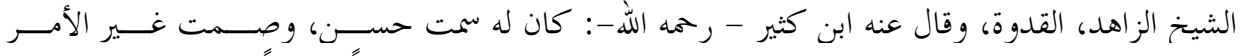

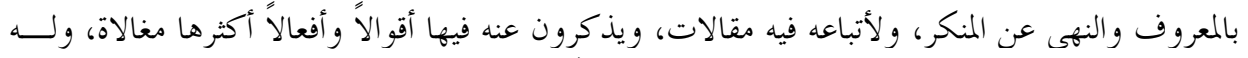

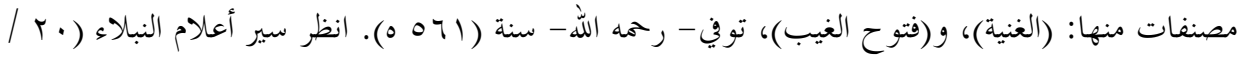

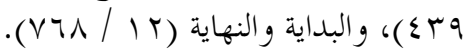

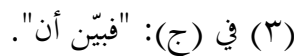

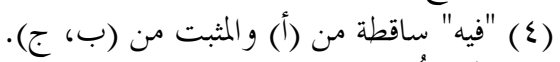

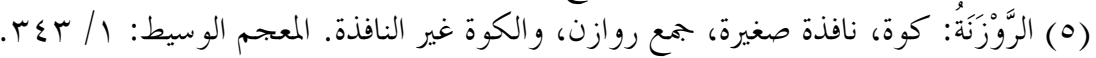

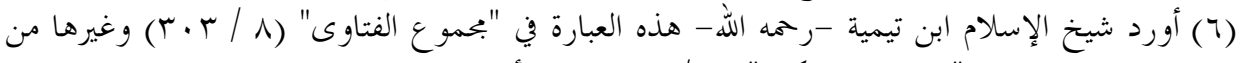

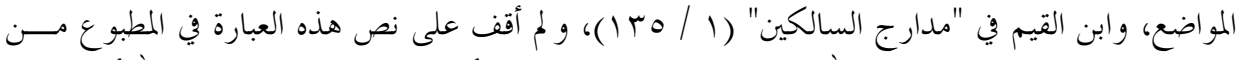

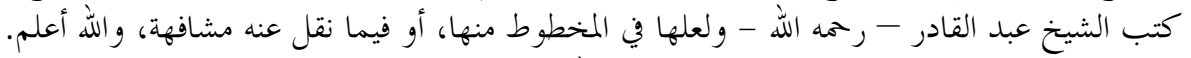

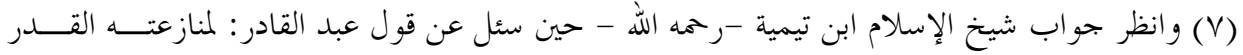

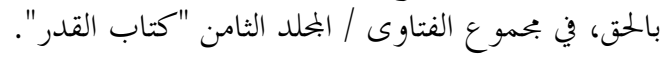


الرِّحال غلطو ا، فِإهم قد يشهدون ما يقدّر على أحدهم من المعاصي والذنوبكأَو ما

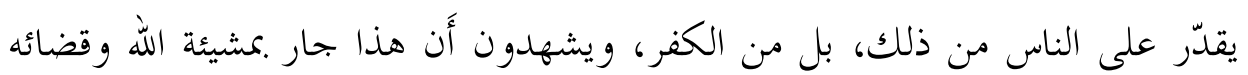

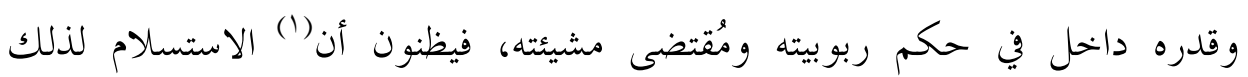
ومو افقته و الرضا به، ونحو ذلك، دينا وطريقا وعبادة، فيضاهون المُشر كين اللَّين قالو ا:

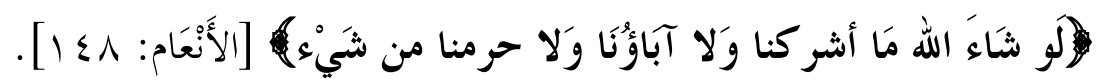

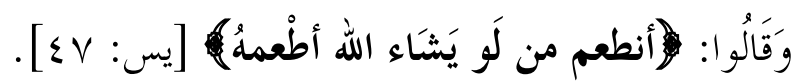

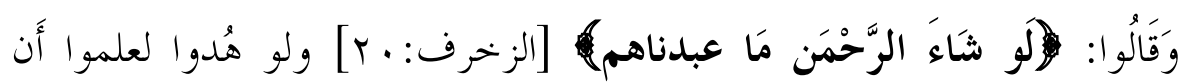
الْقدر أُمرنا أَن نرضى به و ونصبر على موجبه فِي المصائب التَّي تصيبنا كالفقر والمَرض

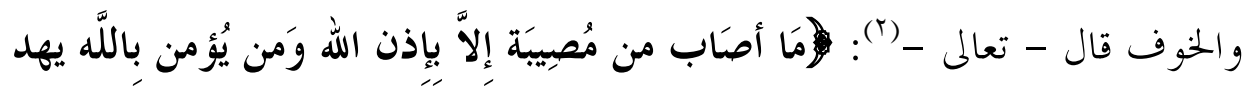
قلبه قال بعض السلف: هو الرجل تصيبه المصيبة فيعلم أنَّها من عند الله فيرضى

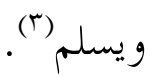

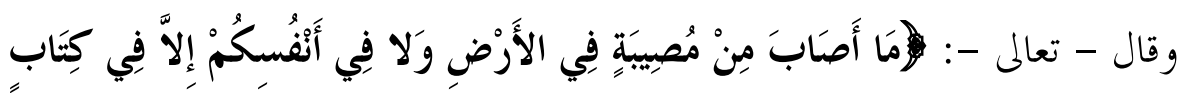

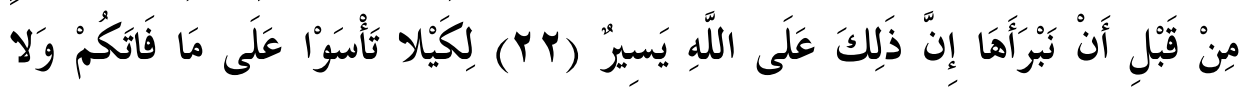

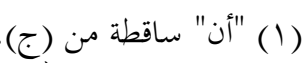

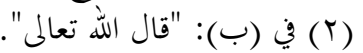

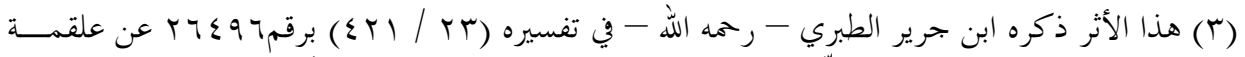

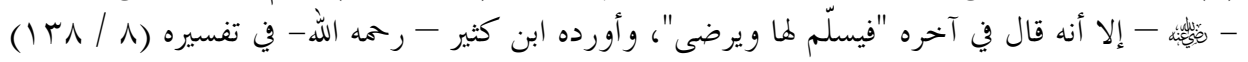

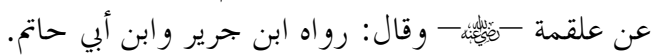

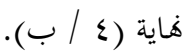
$-r \cdot 1-$ 


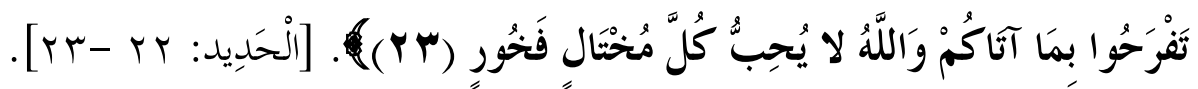

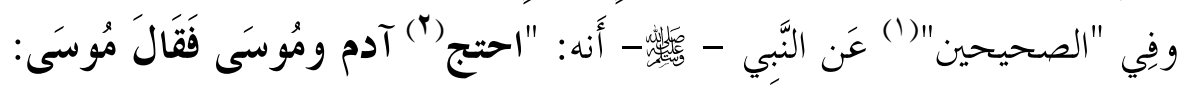

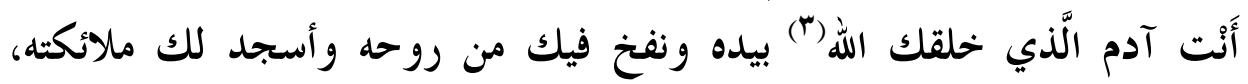

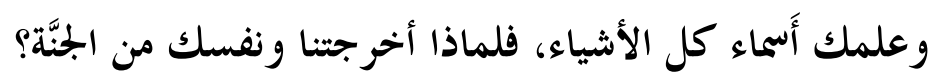

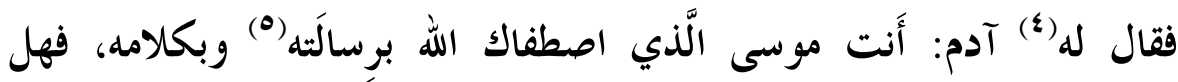

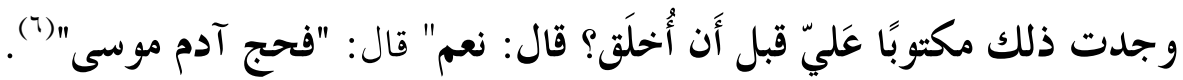

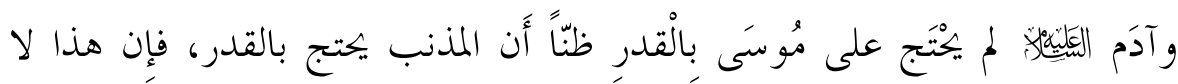

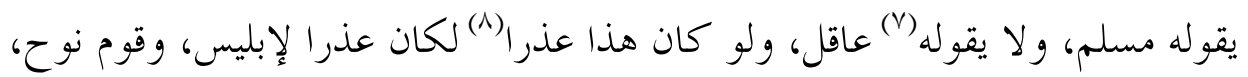

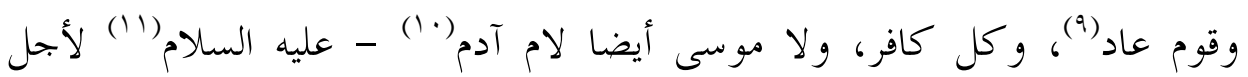

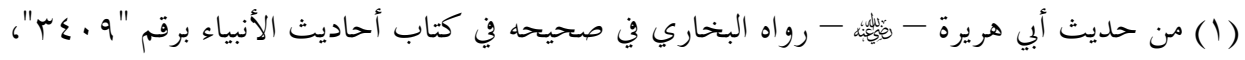

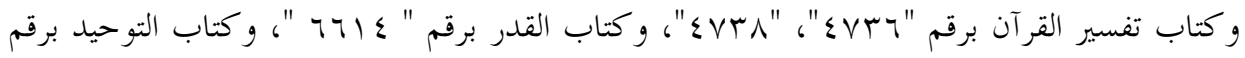

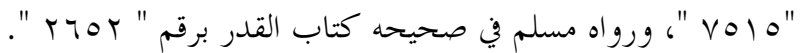

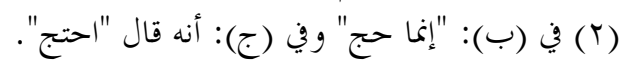

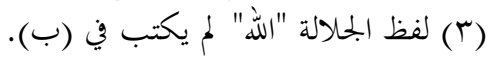

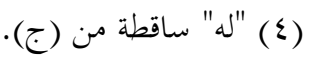

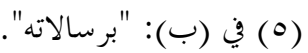

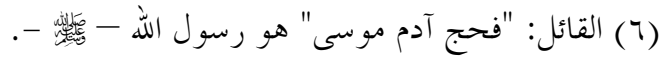

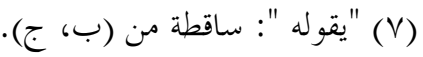

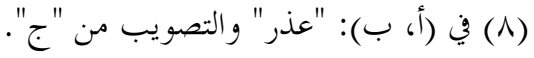

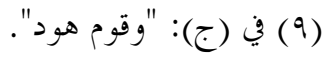

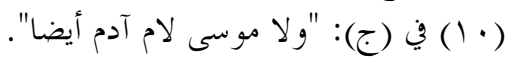

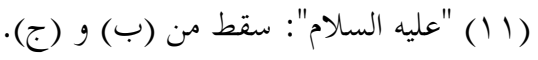


الذَّنب-، فَإن آدم قد تاب الله عليه فاجتباه وهداه(') و ولكن(r) لامه لأجل المُصيبة الَّتي

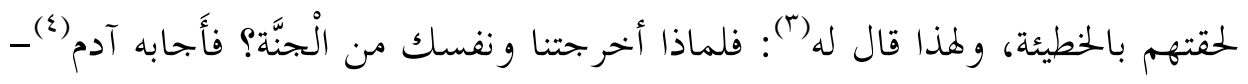
عليه السلام-: بأن هذا كان مكتوبًا قبل أَن يخلق (ْ) فكان وهان العمل و المصيبة المترتبة عليه مقدّرا، وما قُدّر من المصائب بيجب الاستسلام له فِإِنَّه من تَمام الرّضّا باللَّه ربَّا.

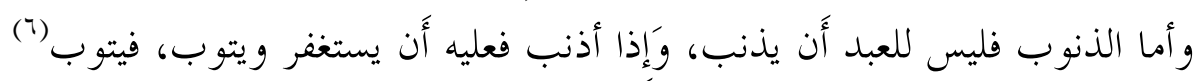
من صنوف المعائب، ويصبر على المصائب(v).

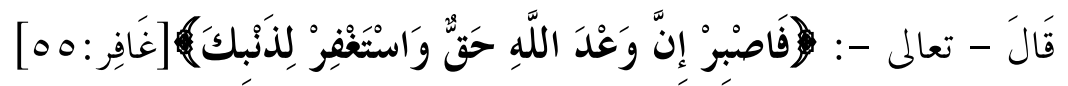

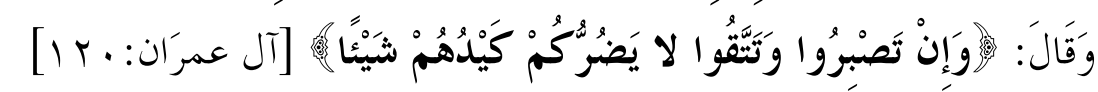

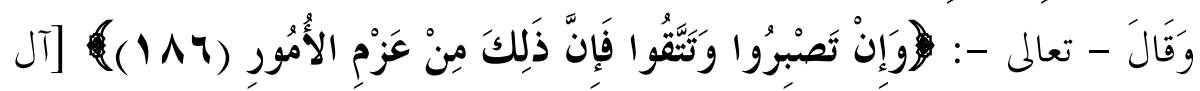
عمرَان:

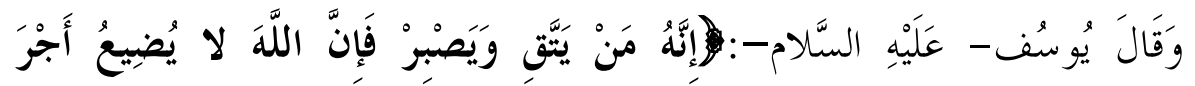

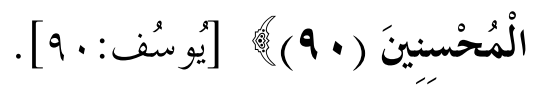

(1) في (ب، ج): "فإن آدم قد تاب إلى ربه فاجتباه وهدى".

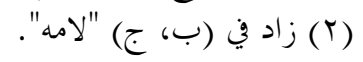

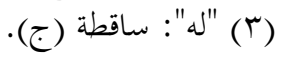

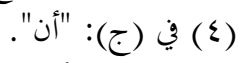

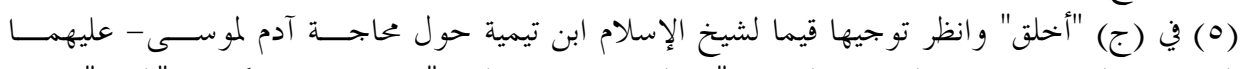

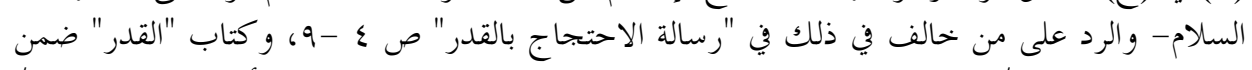

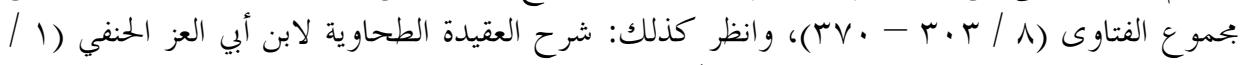

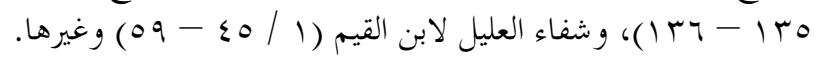

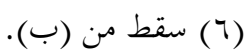

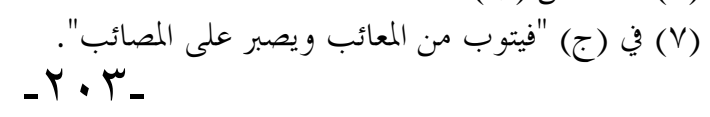




\section{فصل: في الأمر بالمعروف والنهي عن المنكر}

و كذلك ذنوب العباد(') يجب على العبد فيها أن يأمر بالمعروف (ب/ أ) وينهى عن

المنكر- -بحسب قدرته -ويجاهد في سبيل الله الكفار والمنافقين، ويوالي أولياء الله، ويعادي أعداء الله،ويُحب في الله، ويُبغض في الله - تعالى -، (ז) كما قال - تعالى -

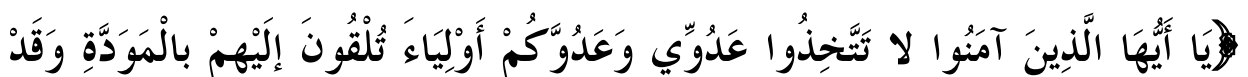

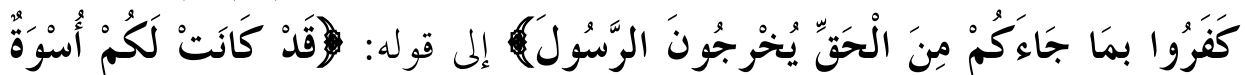

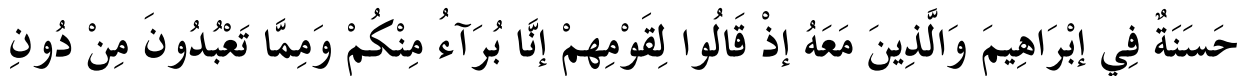

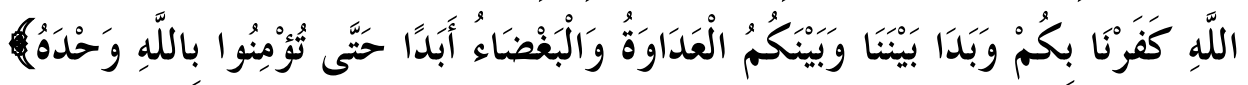

$$
\text { ] }
$$

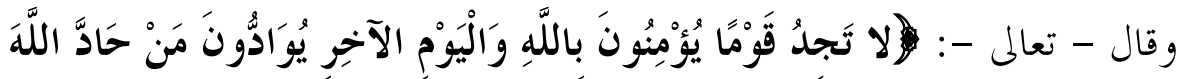

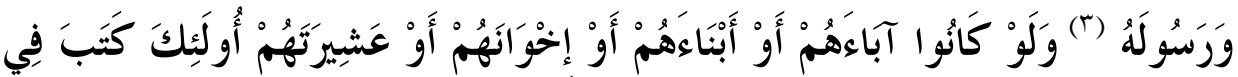

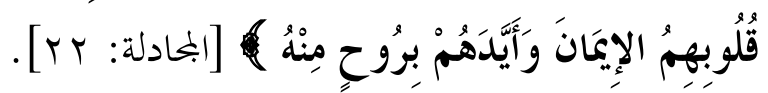

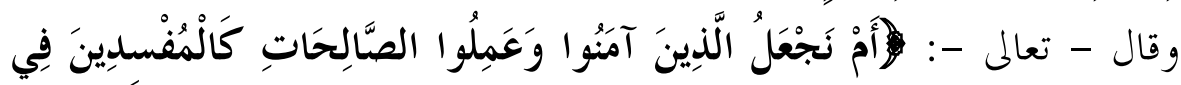

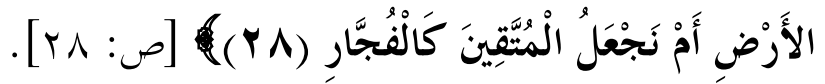

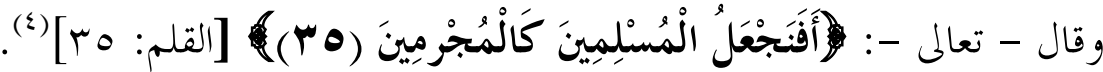

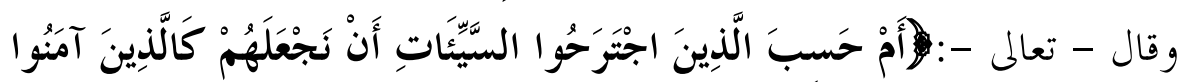

$$
\begin{aligned}
& \text { (1) في (ب): "للعباد". }
\end{aligned}
$$

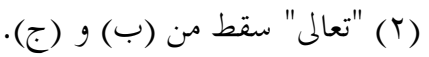

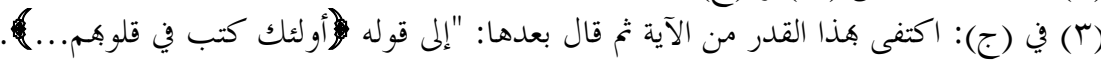

$$
\begin{aligned}
& \text { (ع) في (ج) قدم هذه الآية على الآية السابقة. } \\
& -r \cdot \varepsilon_{-}
\end{aligned}
$$




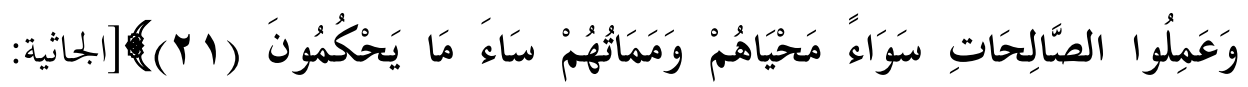

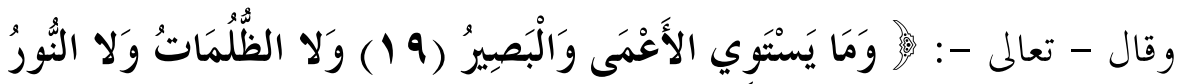

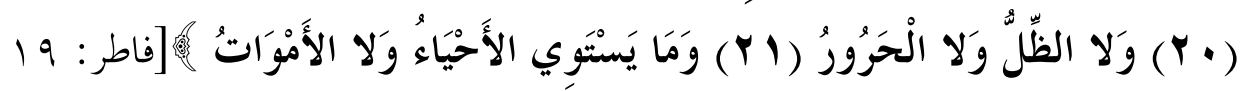
$\cdot[r+$

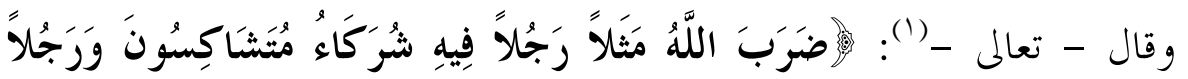

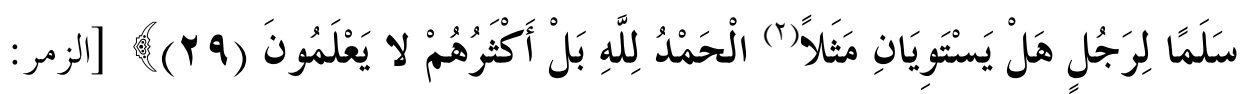
. [ra

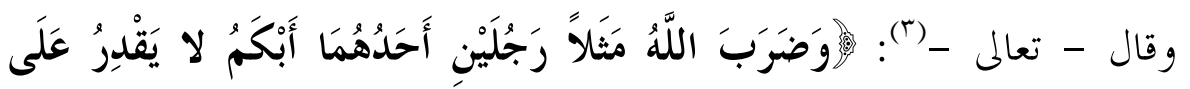

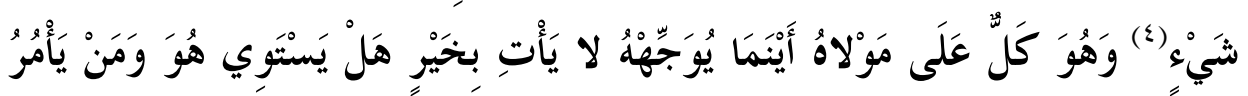

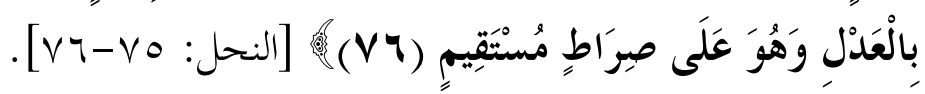

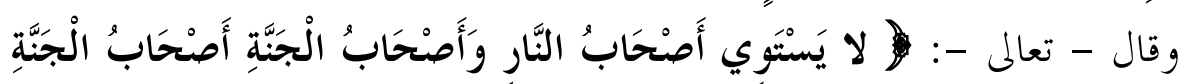

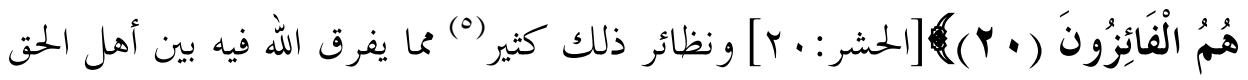
والباطل وأهل المعصية والطاعة(') (ب).

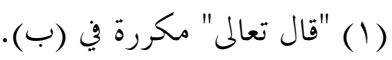

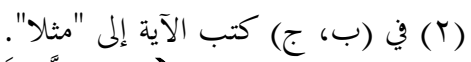

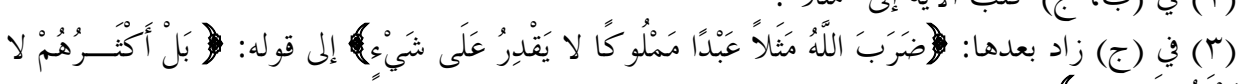

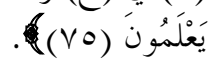

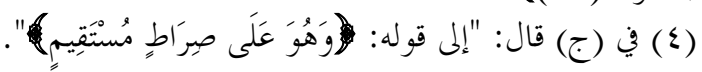

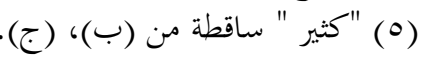
(7) في (ب، ج): "و أهل الطاعة وأهل والمعصية". - Y.O. 
وأهل البر والفجور (1)، وأهل الهدى و الضلال، وأهل الغي والرشاد، وأهل الصدق

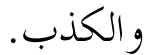

فمن شهد "الحقيقة الكونية" دون الدينية سوَّى بين هذه الأجناس (r) المختلفة التي

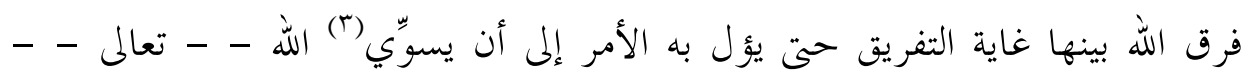

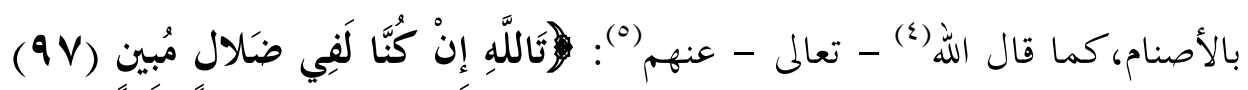

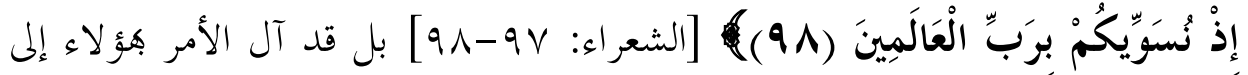

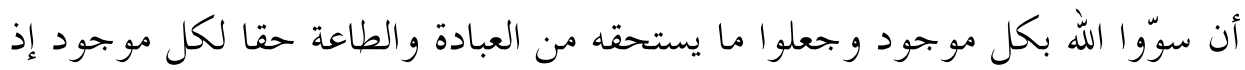

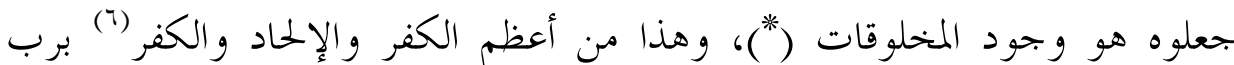
العالمين (v)

وهؤلاء يصل همم الكفر إلى أهم لا يشهدون أهم عباد لا بمعنى أهم معبّدون ولا كعنى أهم (^) عابدون؛ إذ يشهدون أنفسهم هي الحق، كما صرح بذلك طواغيتهم

$$
\begin{aligned}
& \text { (1) في (ج): "وأهل الفجور". } \\
& \text { (ז) في (ب): "الأصناف". } \\
& \text { (ب) في (ب): "سوّى" (ب) الصان }
\end{aligned}
$$

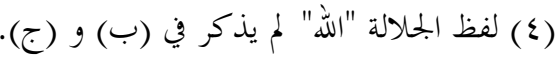

$$
\begin{aligned}
& \text { (0) "عنهم" ساقطة من (ب). }
\end{aligned}
$$

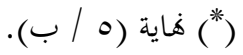

$$
\begin{aligned}
& \text { (7) "والكفر ساقطة من (ج). }
\end{aligned}
$$

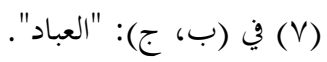

$$
\begin{aligned}
& \text { (^) زاد في (ب، ج) "أفم". }
\end{aligned}
$$


كابن عربي(') صاحب "الفصوص" (r) وأمثاله من الملحدين المفترين كابن سبعين(") وأمثاله، ويشهدون أهم العابدون و المعبودون.

وهذا ليس بشهود للحقيقة لا كونية ولا دينية، بل هو ضلال وعمى عن شهود

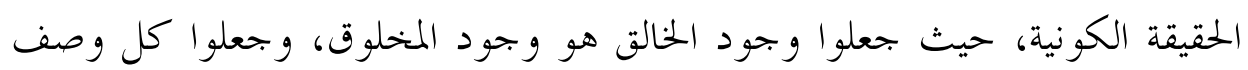

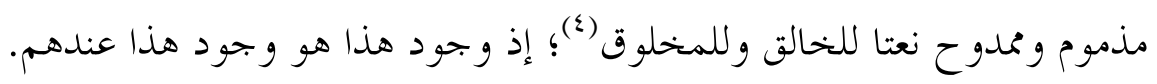

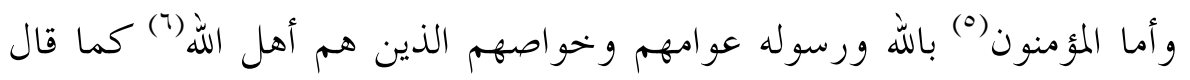
النبي هم أهل الله وخاصته" (') فهؤلاء يعلمون أن الله رب كل شئ شئ ومليكه و خحالقه، وأن

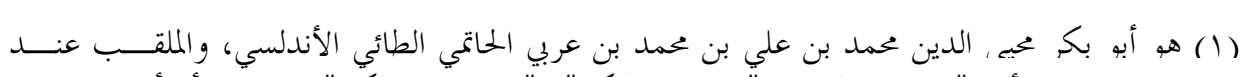

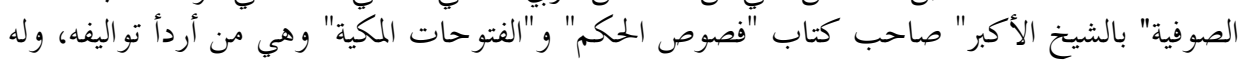

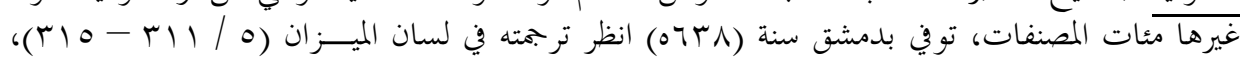

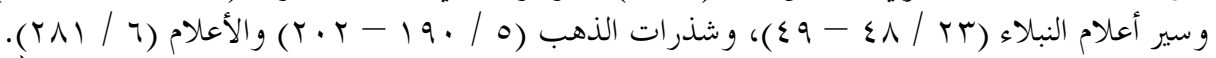

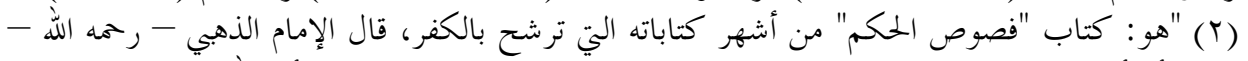

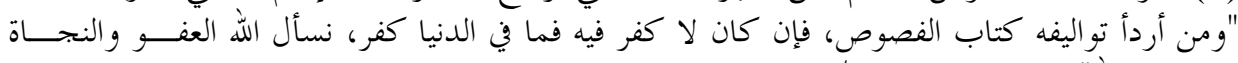

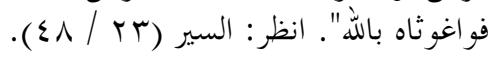

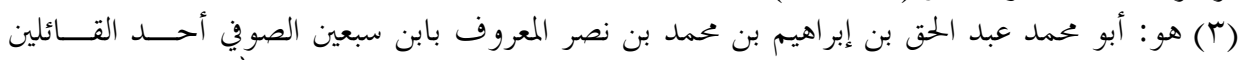

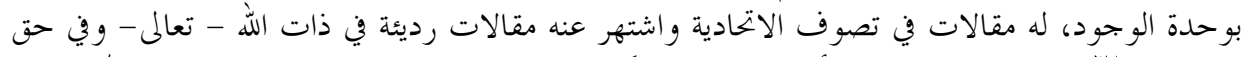

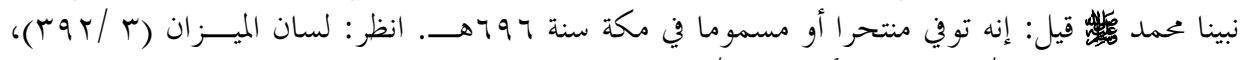

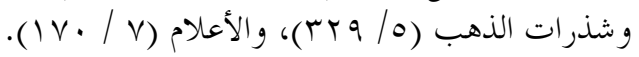

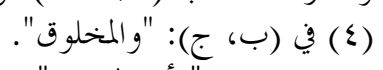

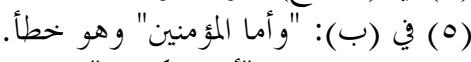

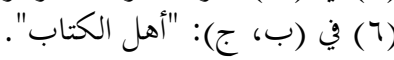

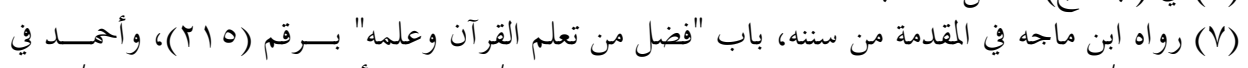

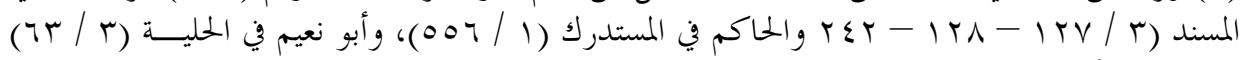

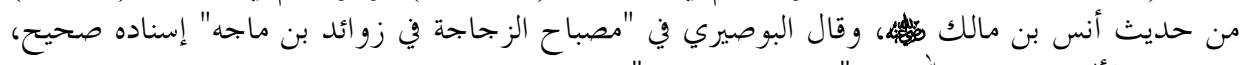

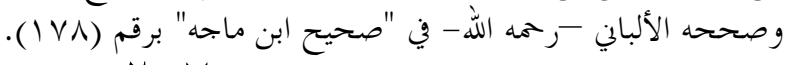
$-r_{-}$ 
الخالق - سبحانه- مباين للمخلوقات (1) ليس هو حالا فيها(') و لا متحدا هها، ولا وجوده وجودها (r)، "و النصارى" إنما كفّرهم الله بأن قالو ا: بالحلول و الاتحاد(ع) بالمسيح

$$
\begin{aligned}
& \text { (1) في (ب): "للمخلوقين"، وفي (ج) "للمخلوق". }
\end{aligned}
$$

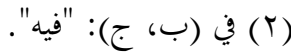

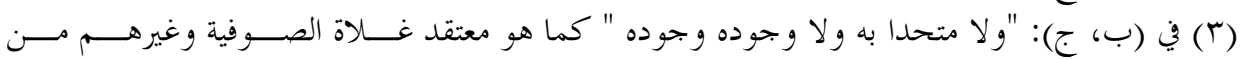

(ع) الحلول والاتحاد من مصطلحات الصوفية والباطنية- الحلول يراد منه في اصطلاح القائلين به:حلول الله الله

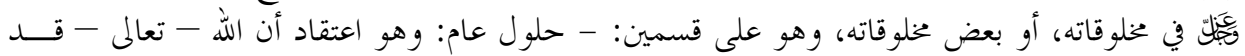

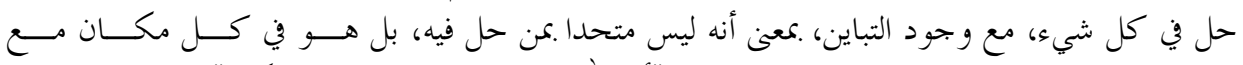

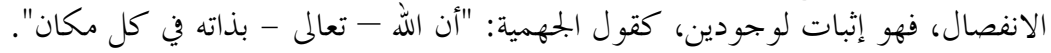

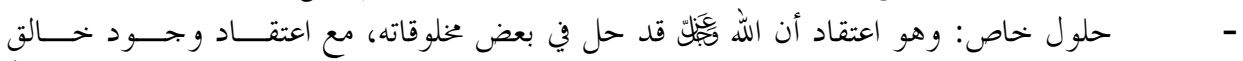

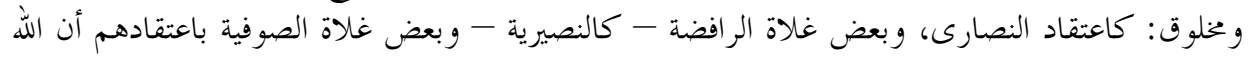

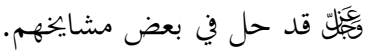

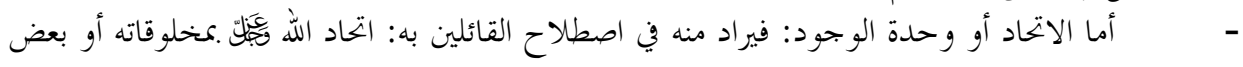

$$
\text { وهلو على قسمين: }
$$

الاتحاد العام: وهو اعتقاد كون الوجود هو عين الله - تعالى- الله عن ذلك- بمعنى أن الحــالق

متحد بالمخلوقات جميعها.

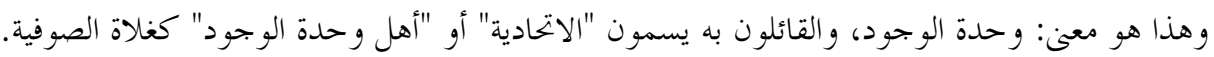

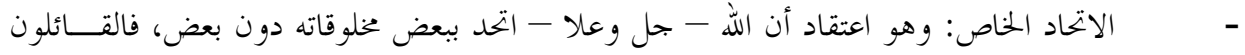

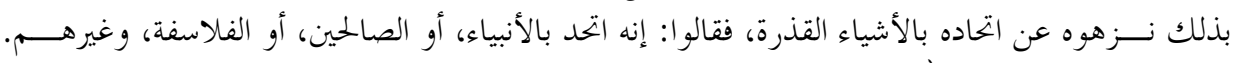

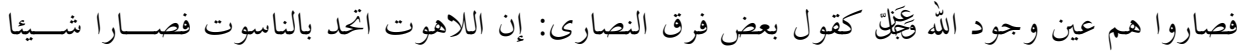
واحدا، و وبعض الغلاة من الصوفية.

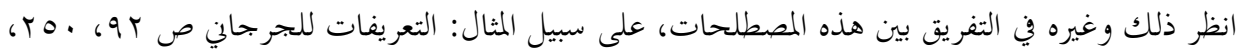

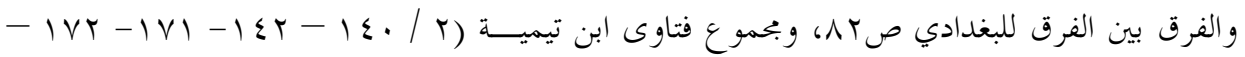

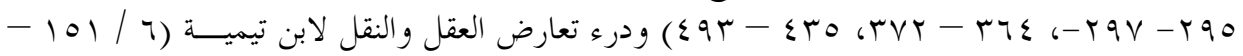

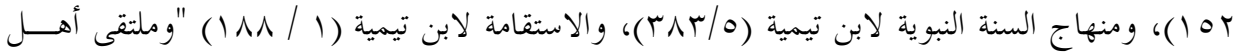

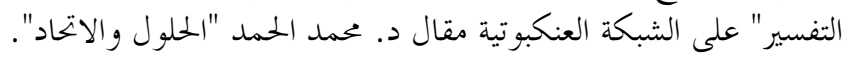




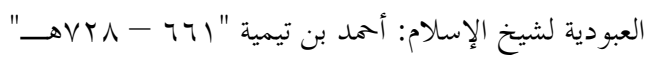

د. منيرة بنت عبد الله الراجحي

خاصةً، فكيف من جعل (1) ذلك عاما في كل مخلوق؟ و يعلمون مع ذلك أن الله أمر بطاعته وطاعة رسوله، وفى عن معصيته ومعصية

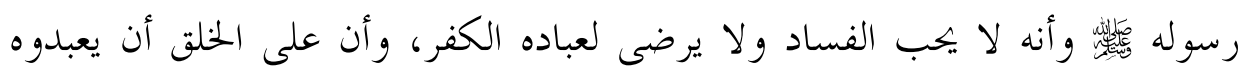

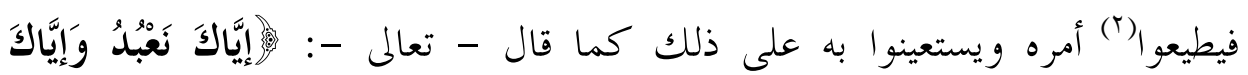

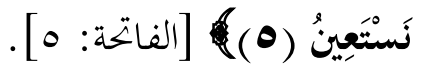
ومن عبادته وطاعة أمره: الأمر(r) بالمعروف و النهي عن المنكر - بحسب الإمكان -، والجهاد في سبيله لأهل الكفر و النفاق فيجتهدون في إقامة دينه، مستعينين به، دافعين مزيلين بذلك ما قدر من السيئات، دافعين بذلك ما قد يخاف من (آثار) ذلك، كما يزيل الإنسان الجوع الحاضر بالأكل، ويدفع به الجوع المستقبل، وكذلك إذا أزال البرد

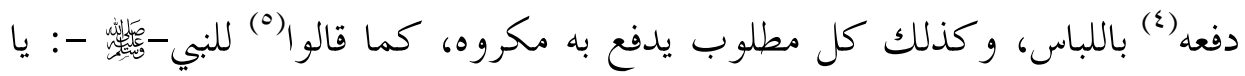

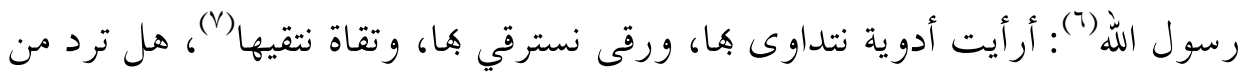
قدر الله شيئا؟ فقال: "هي من قدر الله"(^).

$$
\begin{aligned}
& \text { (1) في (ب): "بمن فعل". }
\end{aligned}
$$

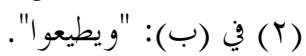

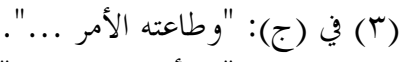

$$
\begin{aligned}
& \text { (ع) في (ج): "آن أوان البرد دفعه". }
\end{aligned}
$$

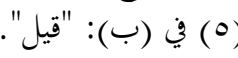

$$
\begin{aligned}
& \text { (7) جملة "يا رسول الله" ساقطة من (ب) (ج). } \\
& \text { (ج) }
\end{aligned}
$$

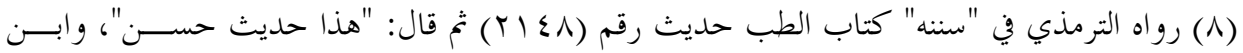

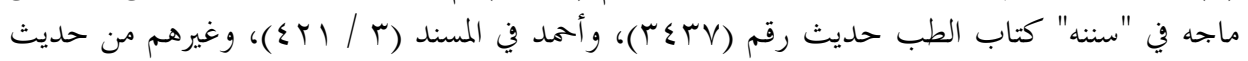

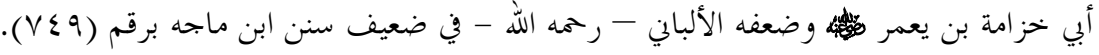


و وي الحديث: "إن الدعاء والبلاء ليلتقيان فيعتلجان(1) بين السماء والأرض"(ب". فهذا حال المؤمنين بالله ورسوله - مئل

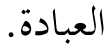

وهؤلاء الذين يشهدون "الحقيقة الكونية"وهي (r) ربوبيته - تعالى - لكل شيء، ويجعلون ذلك مانعا من اتباع أمره الديني الشرعي على مراتب في الضلال:

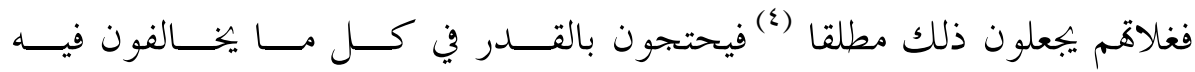
(الشر يعة) (0) وقول هؤلاء شر من قول اليهود والنصارى، وهو من جنس قول المشركين الذين

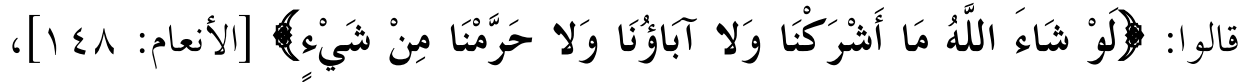

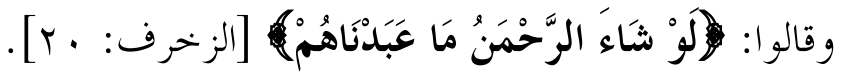

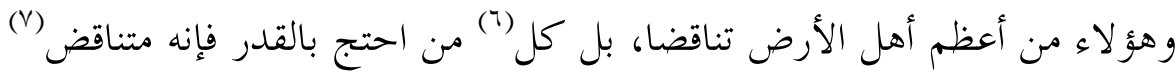

$$
\text { (1) (1) (1) رواه: يتصار عان فأيهما غلب أصاب. }
$$

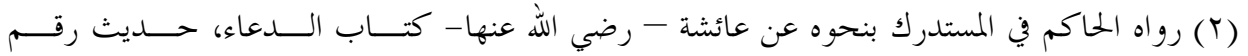

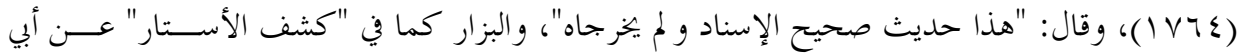

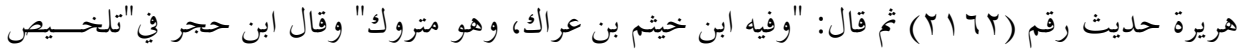

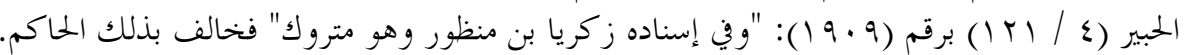

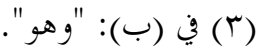

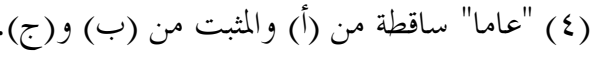

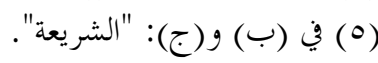

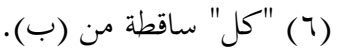
. (أ) / $/)^{*}$

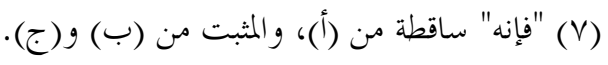


فإنه لا يمكنه( (1) أن يقرَّ كل آدمي على ما فعل، فلا بد (ז) إذا ظلمه ظالم، أو ظلم الناس ظالم، وسعى في الأرض بالفساد، وأحذ يسفك دماء الناس، ويستحل الفروج، ويهلك الحرث والنسل * ونحو ذلك من أنواع الضرر التي لا قوام للناس هها، أن يدفع هذا

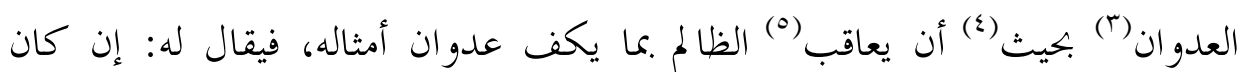
القدر حجة فدع كل أحد يفعل ما يشاء بك وبغيرك، وإن لم يكن حجة بطل أصل قولك: [إن القدر حجة].

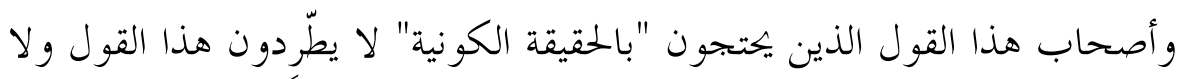

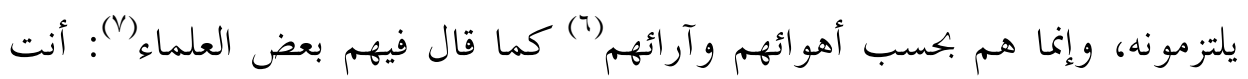
عند الطاعة قدري، وعند المعصية جبري، أي مذهب و وافق هو اك تمذهبت به؟!

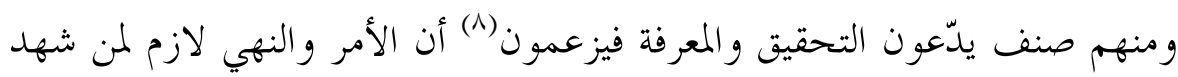

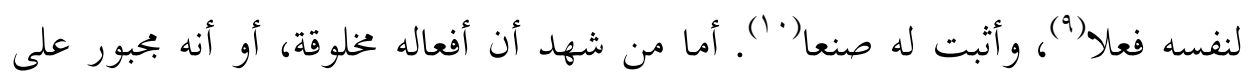

$$
\begin{aligned}
& \text { (1) في (ج): "لا بمكن". } \\
& \text { ) } \\
& \text { (צ) (צ) في (ب): "القدر". }
\end{aligned}
$$

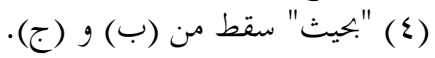

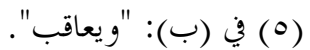

$$
\begin{aligned}
& \text { (T) في (أ): "آراءهم وأهو اءهم" و والتصويب من (ج). }
\end{aligned}
$$

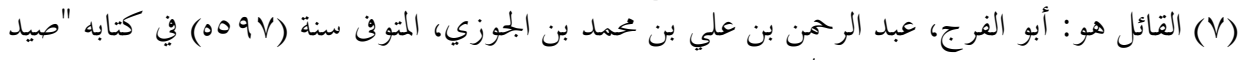

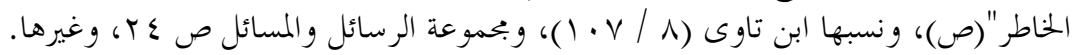

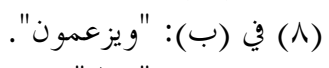

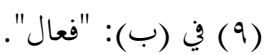

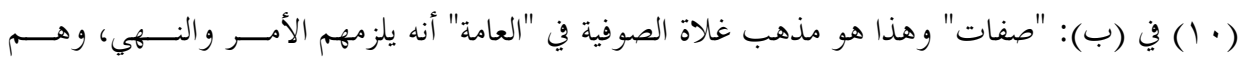

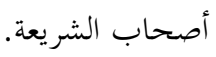


ذلك(') وأن الله هو المتصرف فيه كما يحرك (؟) سائر المتحر كات، فإنه يرتفع عنه الأمر و النهي، و الوعد و الوعيد (r) وقد يقولون: "من شهد الإرادة"(ع) سقط عنه التكليف. ويزعم أحدهم أن "الخضر "(0) سقط عنه التكليف لشهوده " الإر ادة.

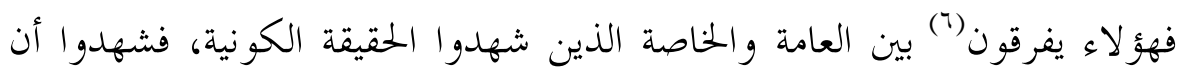

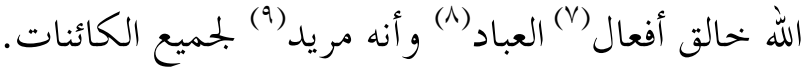

$$
\text { (r) (r) في (ب): "(ب) "فإن". }
$$

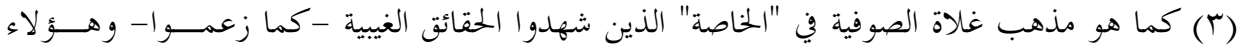

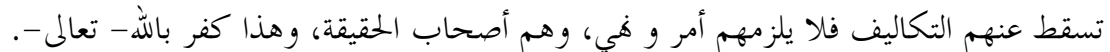

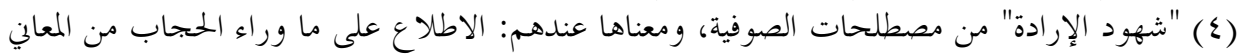

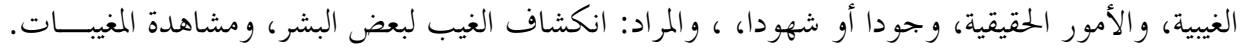

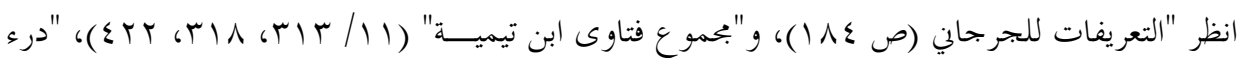

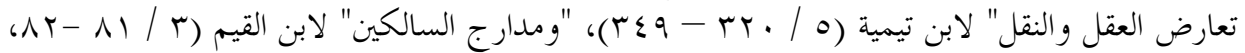
. ( TY人 6 111- - 11.

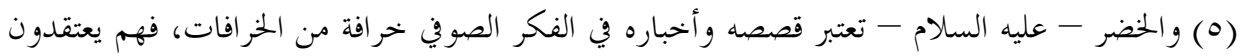

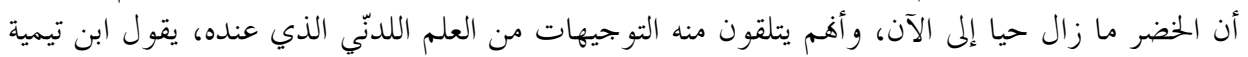

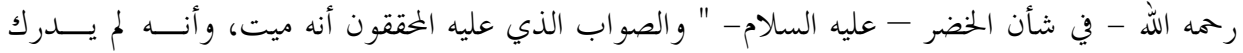

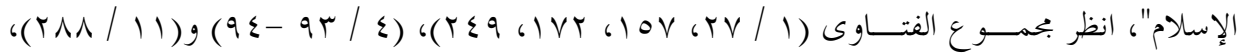

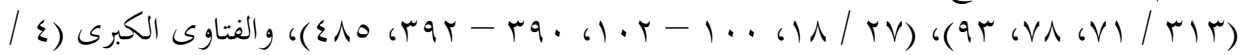

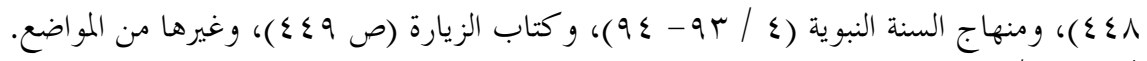

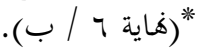

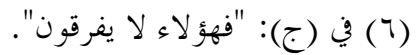
(Y) في (ب): "الأفعال".

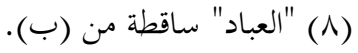

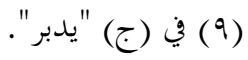


وقد يفرقون بين من يعلم ذلك علماً، و بين من يراه شهوداً، فلا يسقطون التكليف

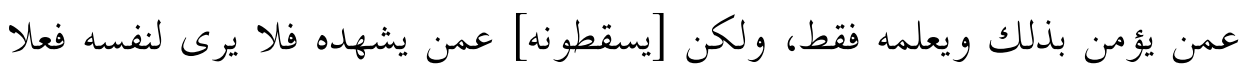
أصلا.

وهؤلاء يجعلون الجبر (1)، وإثبات المقدور(') مانعا من التكليف على هذا الوجه. وقد وقع في هذا طو ائف من المنتسبين إلى التحقيق والمعرفة والتوحيد. و سبب ذلك:

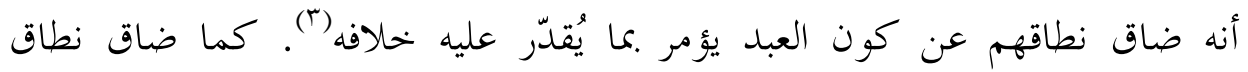

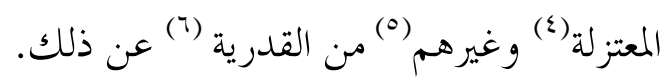

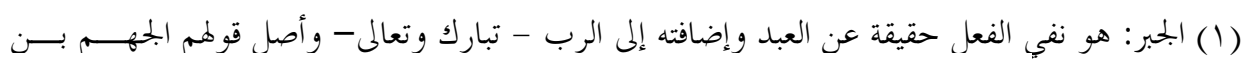

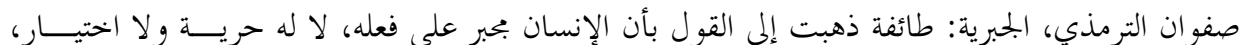

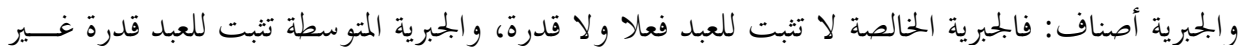

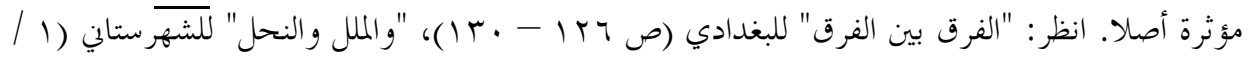

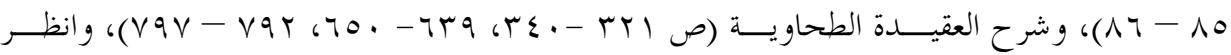
اختلاف المذاهب في القدرة وأفعال العباد والقول العناول الحق فيها. ( )

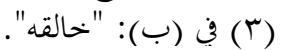

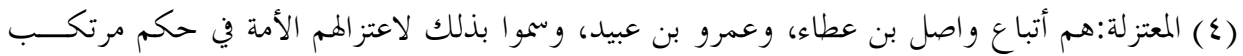

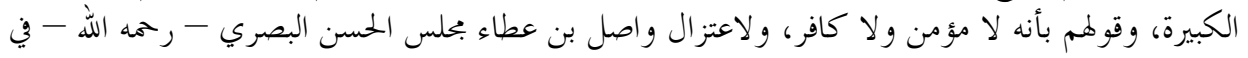

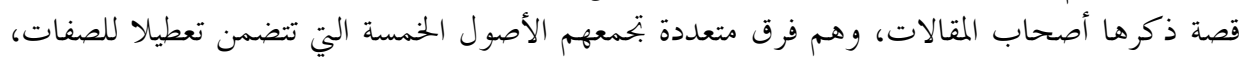

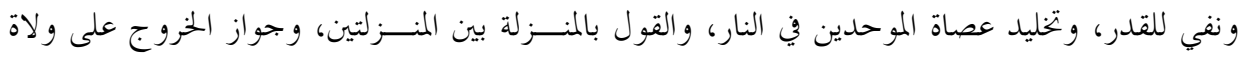

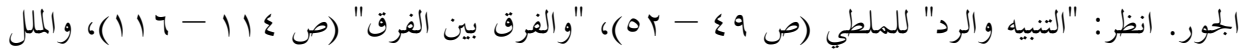

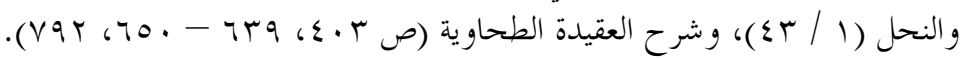

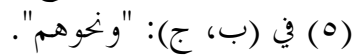

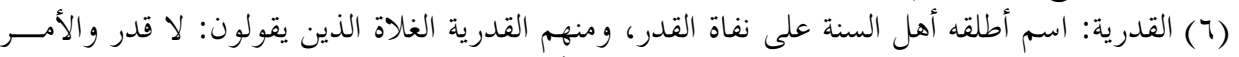

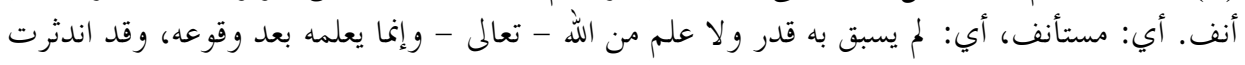

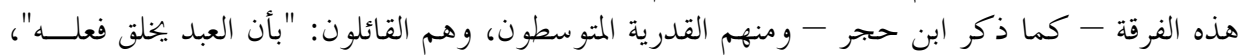

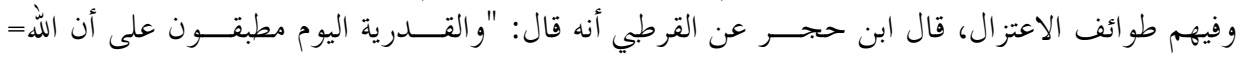


ثم المعتزلة أنبتت الأمر و النهي الشرعيين وردت القضاء والقدر الذي هو: إرادة الله

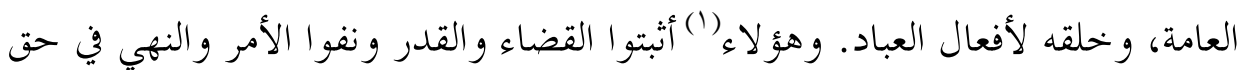

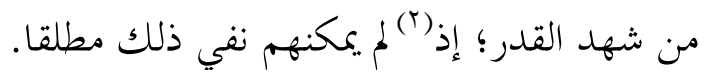
وقول هؤلاء شر من قول المعتزلة؛ ولهذا لم يكن في السلف (r) من هؤلاء أحد،

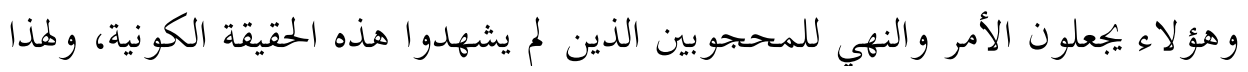

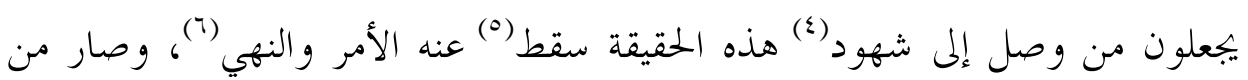

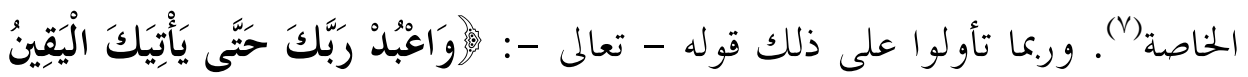

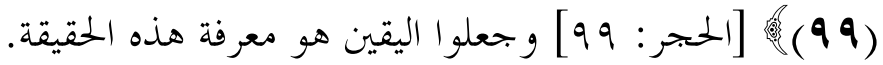

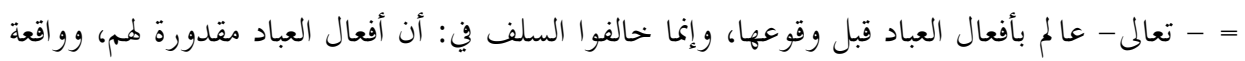

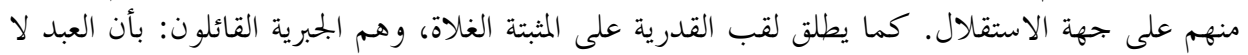

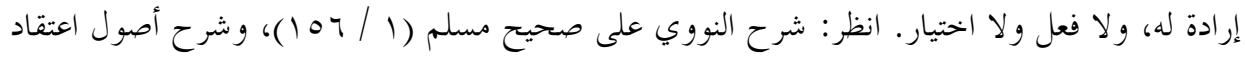

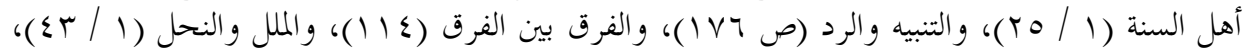

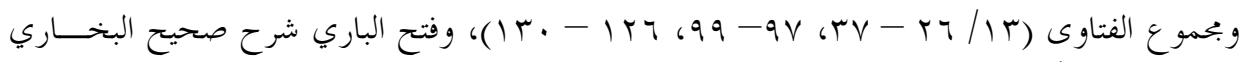

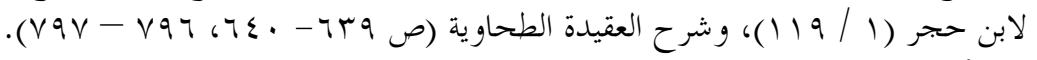

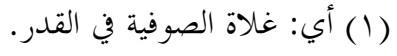

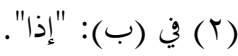

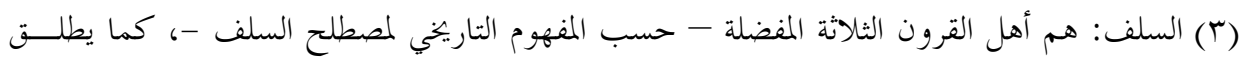

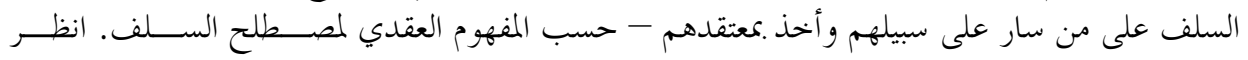

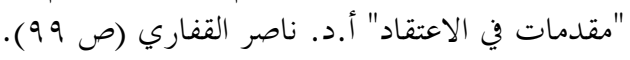

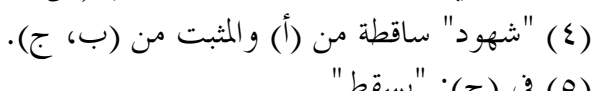

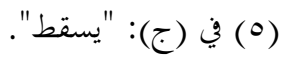
(7) في (ب) زاد بعدها: "وصار الى شهود هذه الحقيقة" سقط عنه الأمر و النهي، وهو تكرار وتصــحيف في بعض الكلمات.

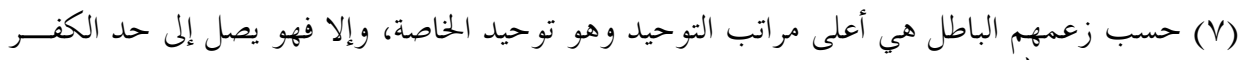

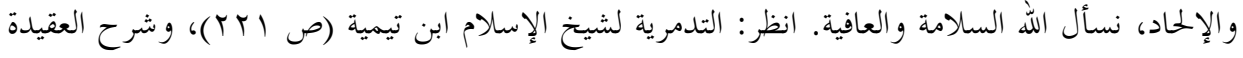

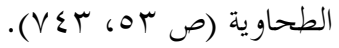


وقول هؤلاء كفر صريح، وإن وقع فيه طو ائف لم يعلموا أنه كفر(')فإنه (ז) قد علم

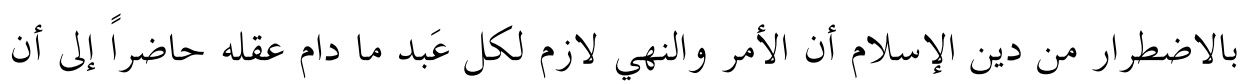

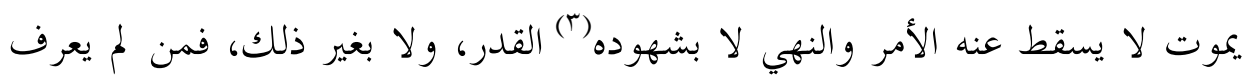

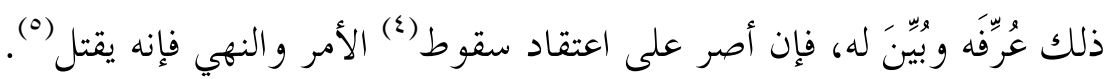

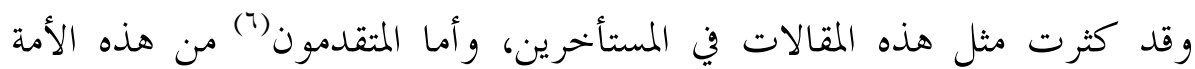
فلم (V) تكن هذه المقالات معروفة فيهم. وهذه المقالات هي محادة(^) لله ورسوله، ومعاداة له ومهن وصد عن سبيله، ومشاقة له،

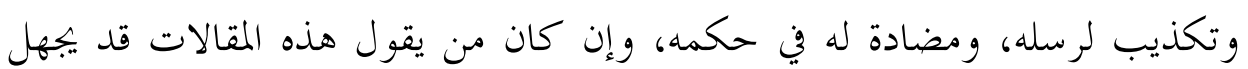

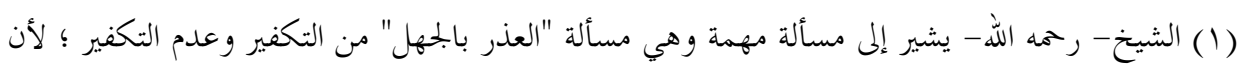

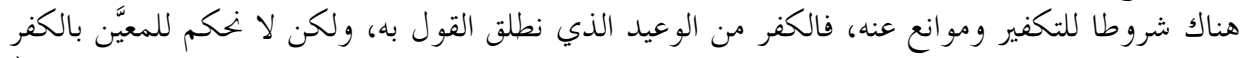

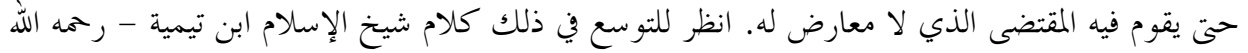

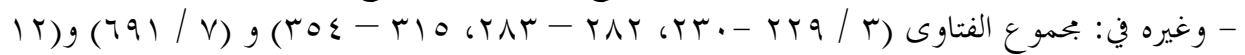

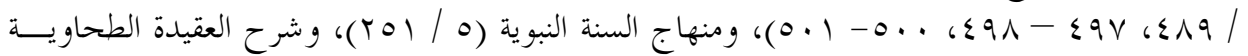

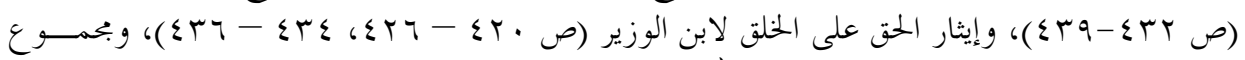

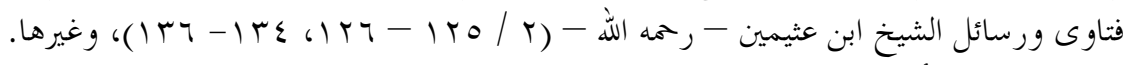

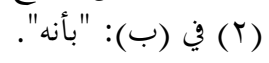

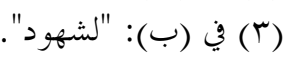

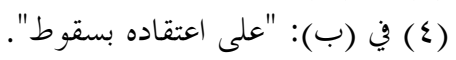

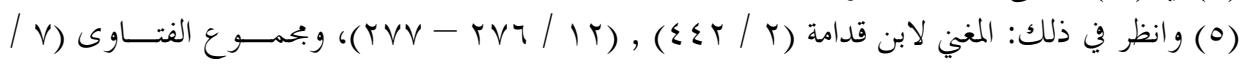

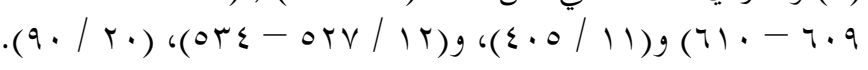

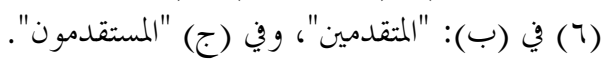

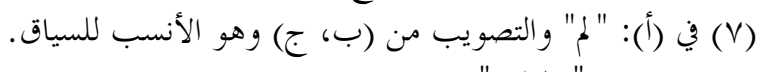

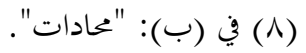


ذلك، ويعتقد أن هذا الذي هو عليه هو (')طريق الرسول، وطريق أولياء الله المققين،

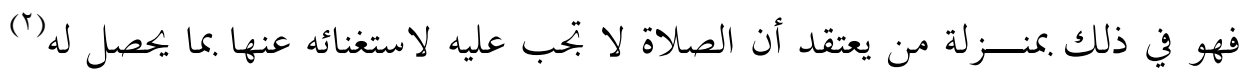

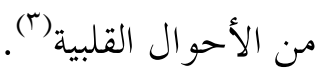

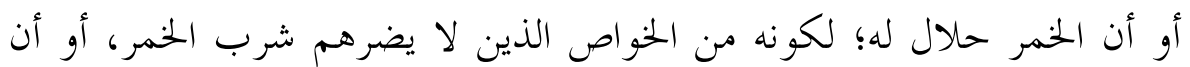

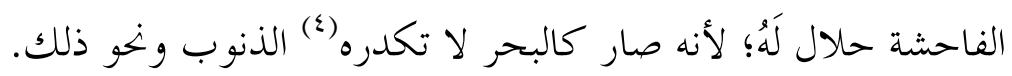

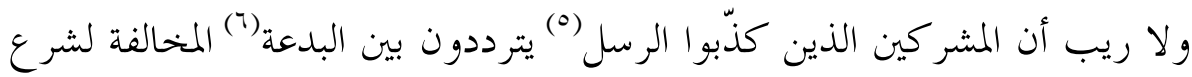

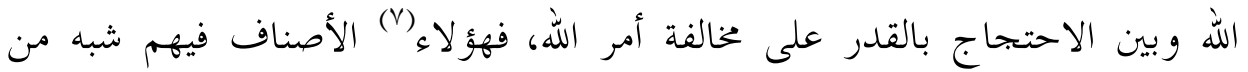
المشر كين؛ إما أن يبتدعوا، وإما أن يحتجوا بالقدر، وإما أن يجمعوا بين الأمرين، كما

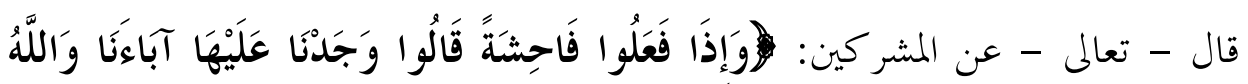

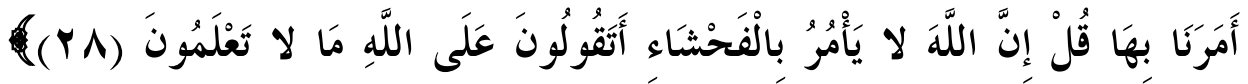

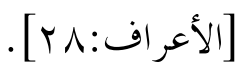

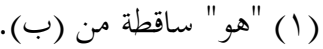

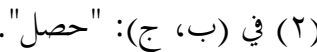

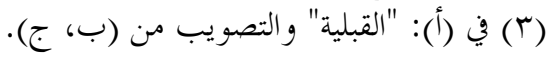

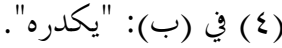

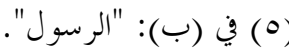

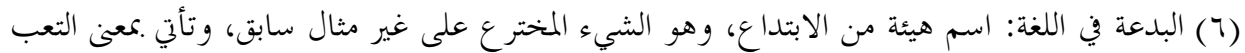

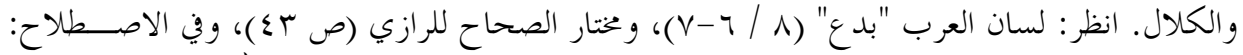

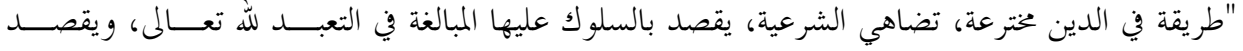

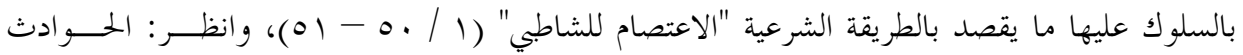

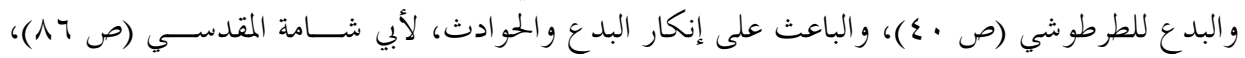

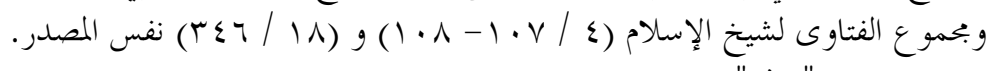

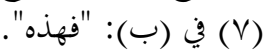




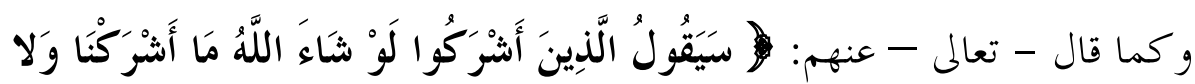

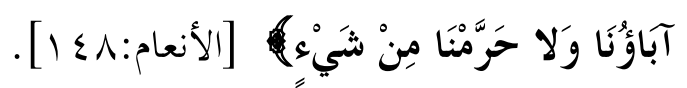

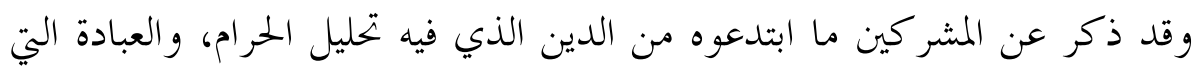

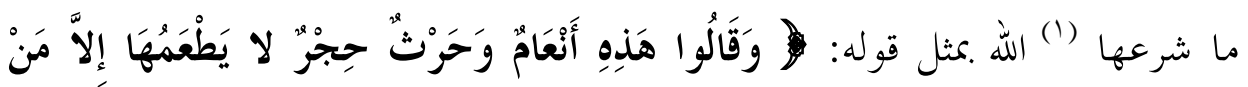

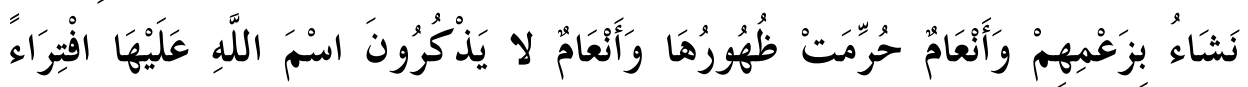

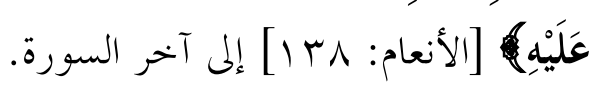

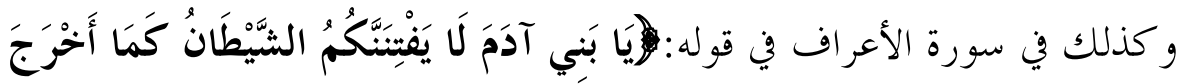

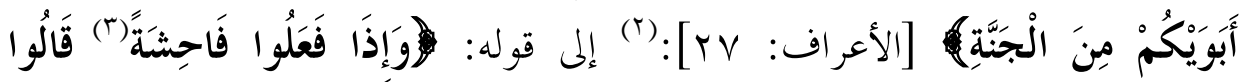

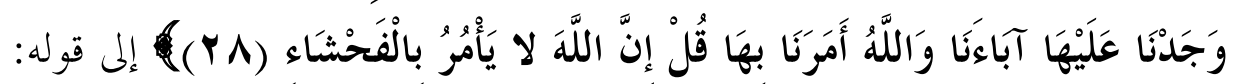

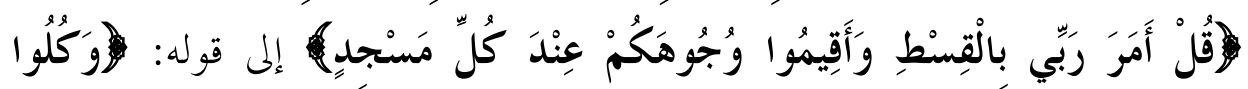

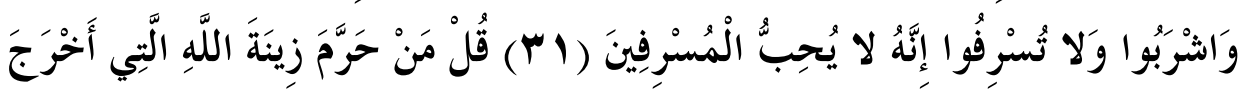

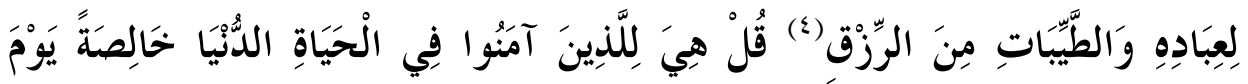

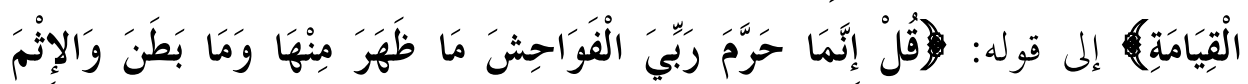

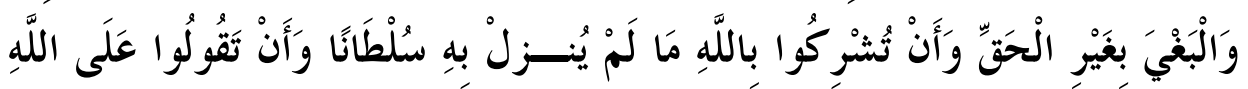

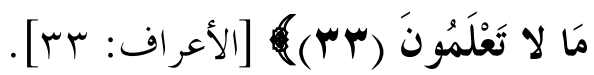

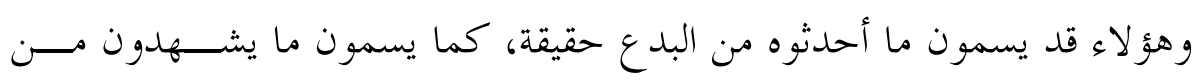

$$
\begin{aligned}
& \text { (1) في (ب) ج): "لم يشرعها". } \\
& \text { (ب) }
\end{aligned}
$$

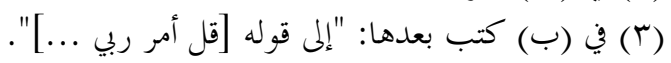

$$
\begin{aligned}
& \text { (צ) في (ج): كتب بعدها: "إلى قوله: [قل إنما حرم ربي ....]". } \\
& -Y \mid V \text {. }
\end{aligned}
$$


القدر حقيقة.

وطريق الحقيقة عندهم هو: السلوك الذي لا يتقيد صاحبه بأمر الشـــارع وهيــه، ولكن .ما يراه ويذوقه ويجده (1) ونحو ذلك.

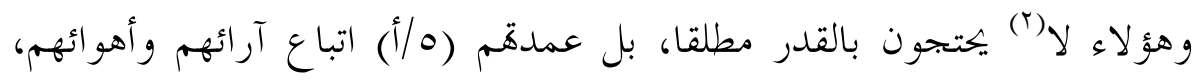

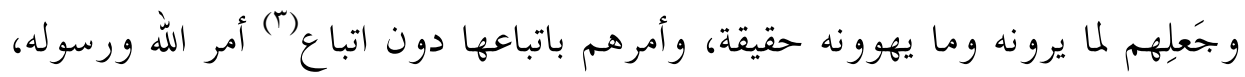

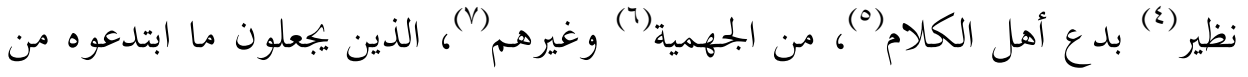
الأقوال المخالفة للكتاب والسنة حقائق عقلية يجب اعتقادها دون ما دلت عليه

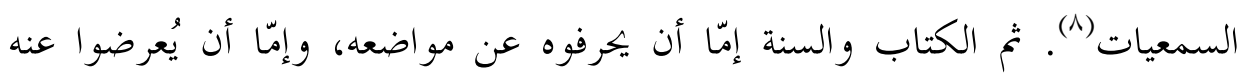
بالكلية(9)، فلا يتدبرونه، ولا يعقلونه، بل يقولون: نُفَّوضُ معناه إلى الله، مع اعتقادهم

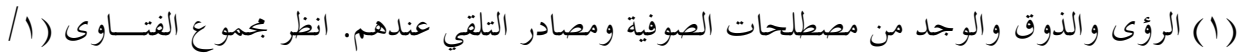

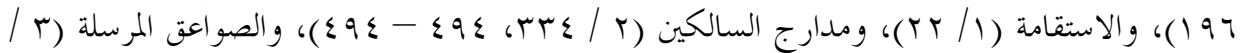

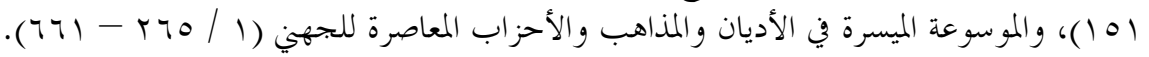

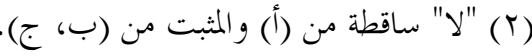

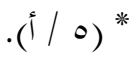

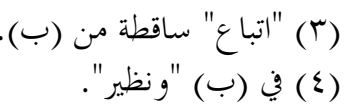

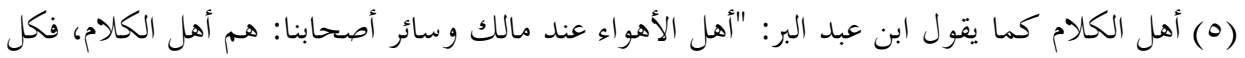

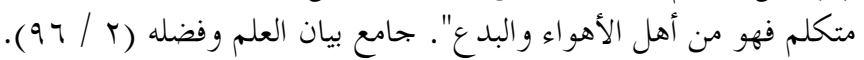

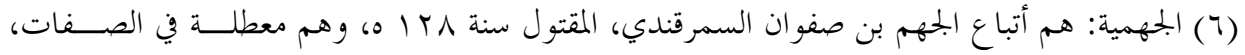

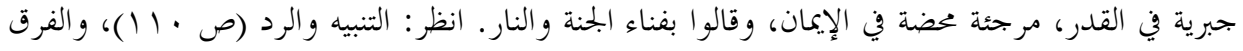

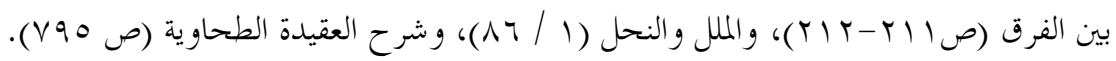

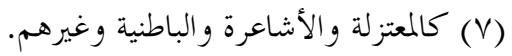

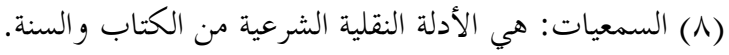

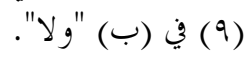


لنقيض(1) مدلوله، وإذا حقق على هؤلاء ما يزعمونه من العقليات المخالفة للكتاب و السنة وجدت جهليات و اعتقادات فاسدة. و كذلك أولئك(r) إذا حقق عليهم ما يزعمونه من حقائق أولياء الله المخالفة للكتاب والسنة، وجدات من الأهو اء التي يتبعها أعداء الله لا أولياؤه.

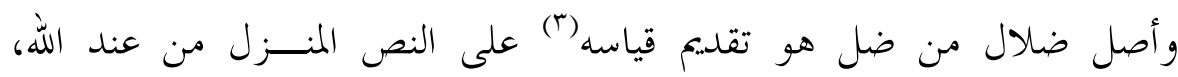

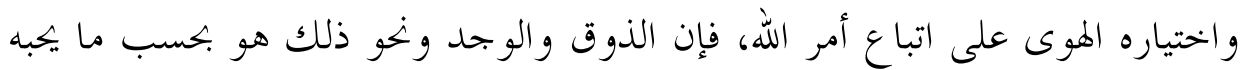
العبد. فكل محب له ذوق ووجد بحسب محبته. فأهل الإيمان لهم من الذوق والوجد مثل ما بينه البي - البئية - بقوله في الحديث الصحيح: "ثلاث من كن فيه وجد حلاوة

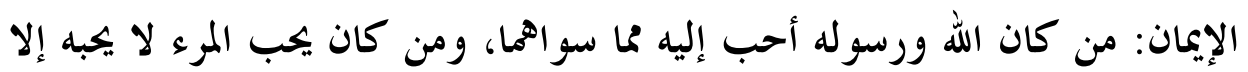
لله، ومن كان يكره أن يرجع في الكفر بعد إذ أنقذه الله منه كما يكره أن يلقى في

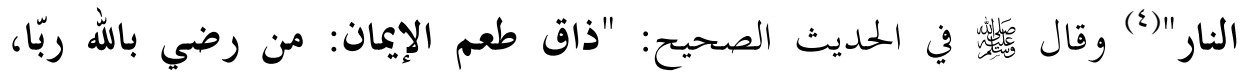
وبالإسلام ديناً، وبمحمد نبيا"(0). وأما أهل الكفر والبدع و الشهوات فكل بحسبه.

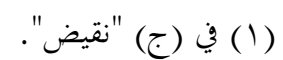

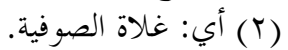

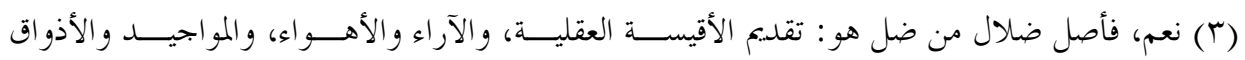

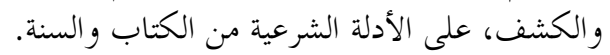

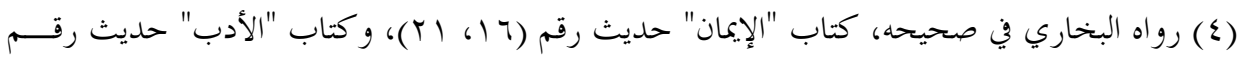

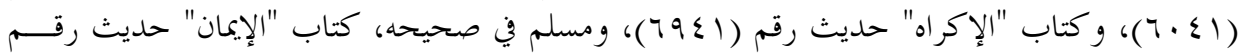
(0)

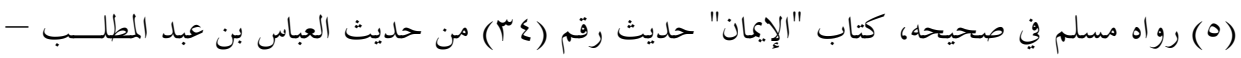

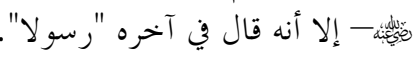


قيل لسفيان بن عيينة:(') "ما بال أهل الأهواء لهم محبة شديدة لأهوائهم؟ قال:(r)

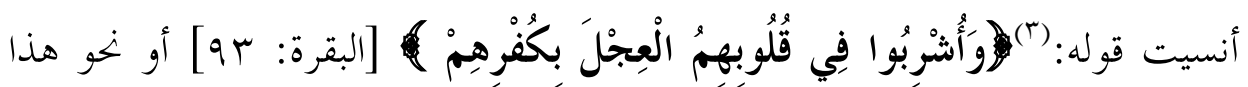

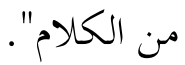

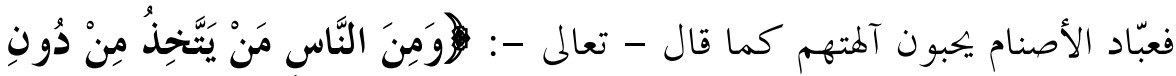

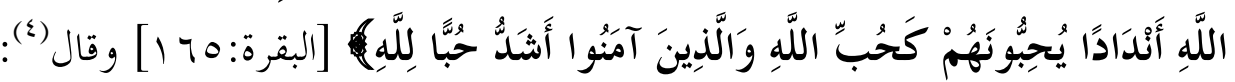

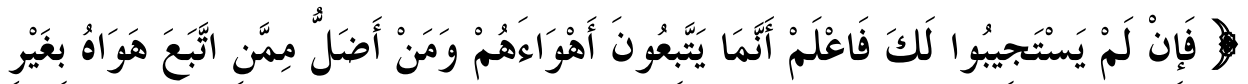
هُدَى مِنَ اللَّهِ

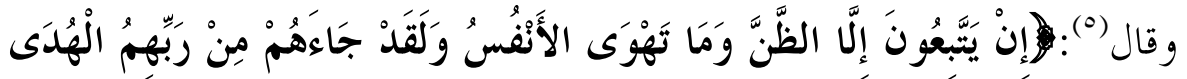
[النجم: (r)

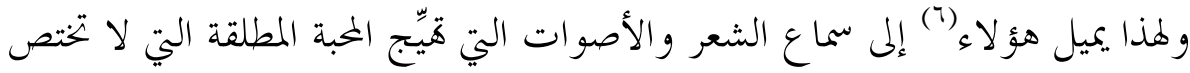

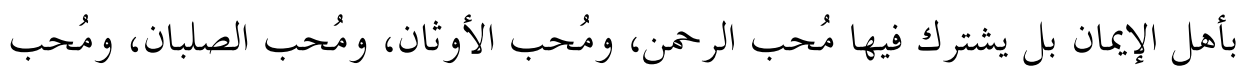
الأوطان، ومُحب الإخوان، ومُحب المردان، ومُحب النسوان، وهؤلاء الذين يتبعون

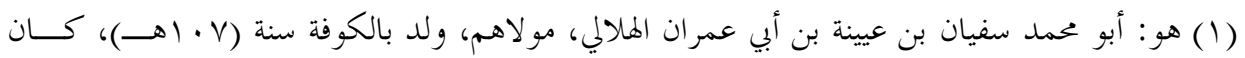

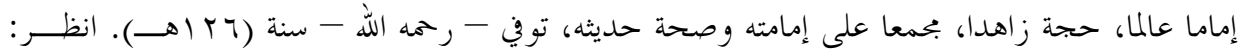

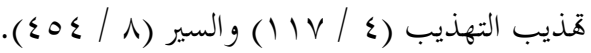

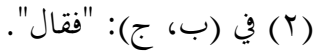

$$
\begin{aligned}
& \text { (؟) }
\end{aligned}
$$

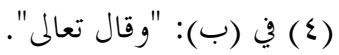

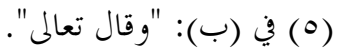

$$
\begin{aligned}
& \text { (7) أي: الصوفية المبتدعة. }
\end{aligned}
$$




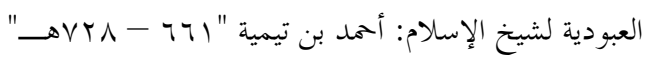

د. منيرة بنت عبد الله الراجحي

أذو اقهم (1) ومو اجيدهم من غير اعتبار لذلك بالكتاب و السنة، وما كان عليه سلف (r) الأمة.

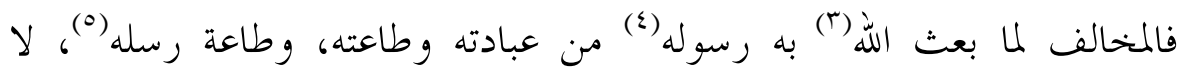

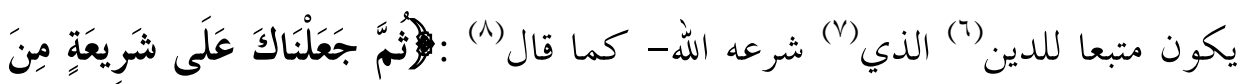

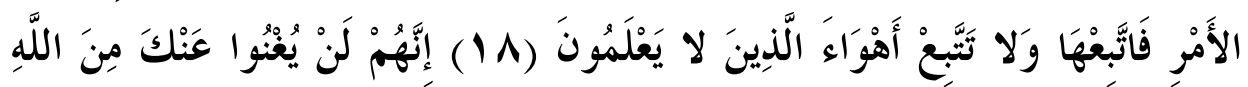

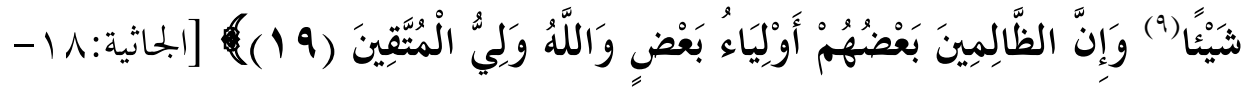

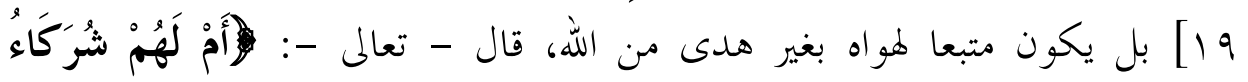

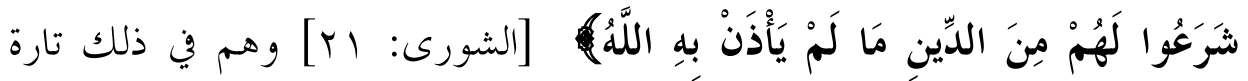

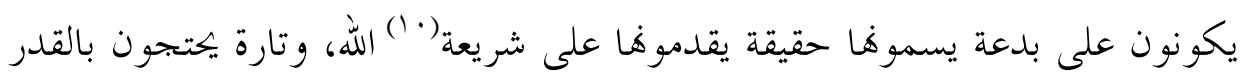

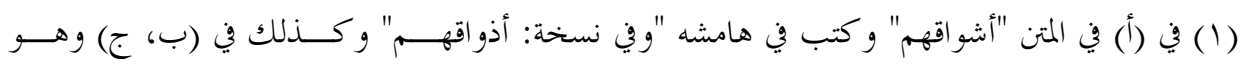
الأنسب للسياق.

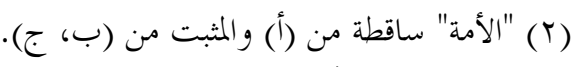

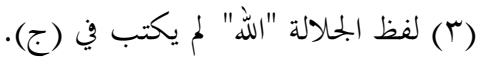

$$
\begin{aligned}
& \text { (ع) في (ب): "رسله". } \\
& \text { (1) في (ج): "رسوله". }
\end{aligned}
$$

(7) من قوله: "للدين الذي شرعه الله" إلى قوله: "بل يكون متبعا" ساقطة من متن (ب) وملحق همامشـــ

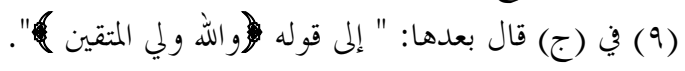


الكوني (1) على شريعة الله (r)، كما أخبر به عن المشركين كما تقدم(r). ومن هؤلاء طائفة هم (๕) أعلاهم قدرا، وهم مستمسكون بالدين في أداء الفرائض المشهورة،

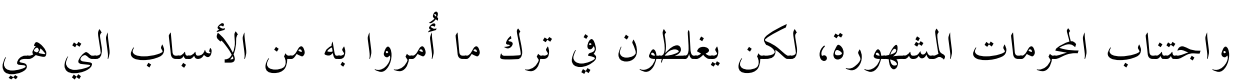

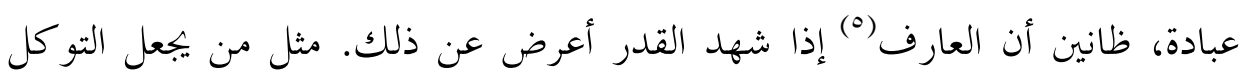

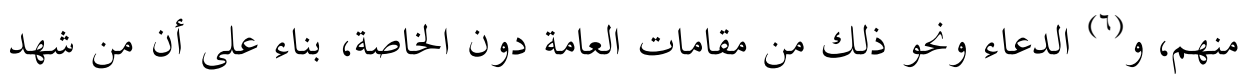

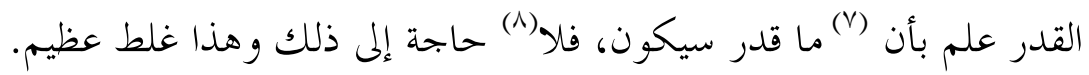

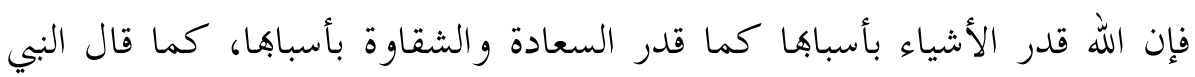

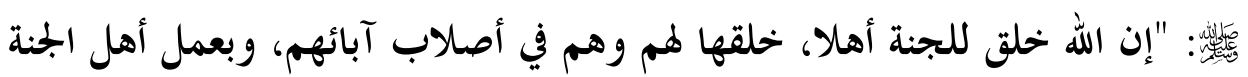

(1) "المققون من أهل السنة يقولون: الإرادة في كتاب الله نوعان: إرادة قدرية كونية خلقية، وإرادة دينية

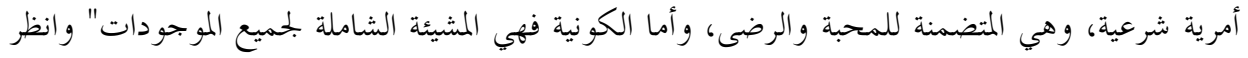

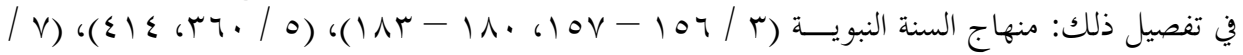
(الس

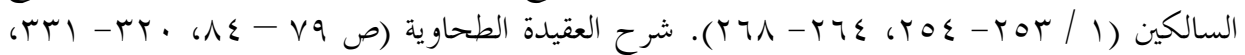

$$
\begin{aligned}
& \text {. (70 - } 7 \mathrm{~V}^{\circ} \\
& \text { (T) في (ج): "على الشريعة". }
\end{aligned}
$$

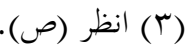

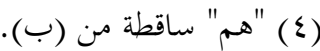

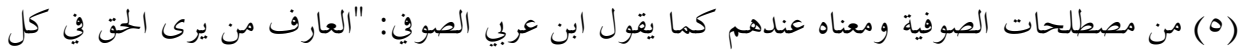

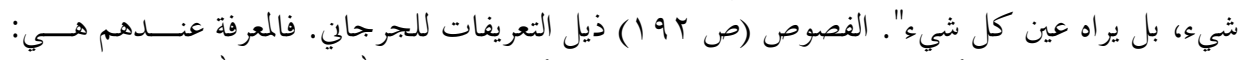

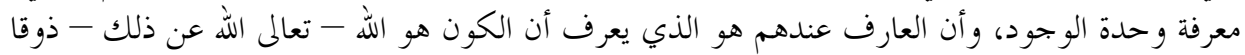

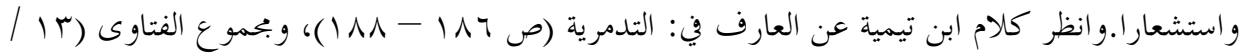

$$
\begin{aligned}
& \text { (ד) في (ب، ج): "أو". }
\end{aligned}
$$

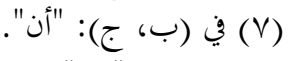

$$
\begin{aligned}
& \text { (^) في (ب) "ولا". }
\end{aligned}
$$


يعملون، * وخلق(1) للنار أهلاً، خلقها لهم وهم في أصلاب آبائهم، وبعمل أهل

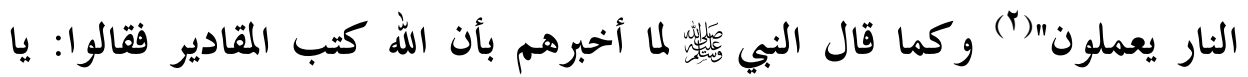
رسول الله أفلا ندع العمل ونتكل على الكتاب؟ فقال: "لا، اعملوا فكل ميسر لما خلق له، أمّا من كان من أهل السعادة فسييسر لعمل أهل السعادة، وأمّا من كان

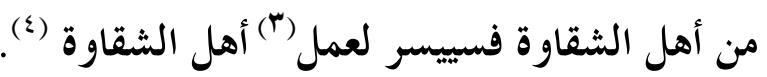

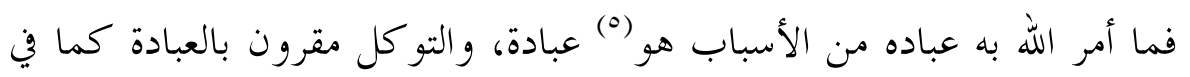

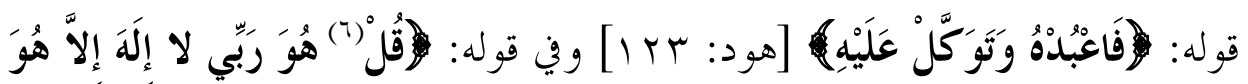

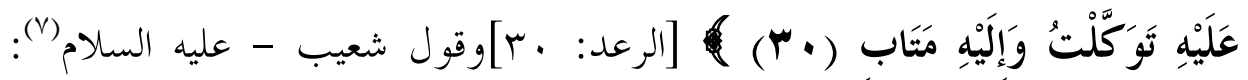

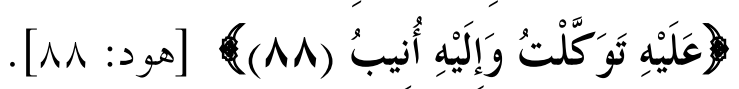
ومنهم طائفة قد تترك المستحبات من الأعمال دون الواجبات، فتنقص بقدر ذلك.

(1) من قوله: "وخلق للنار أهلاً" إلى قوله: "و بعمل أهل النار يعملون" ساقطة من (ج) (ج).

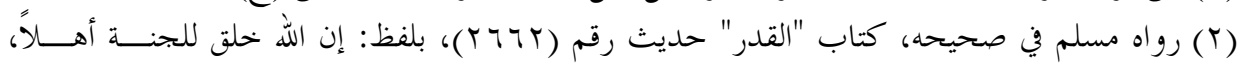

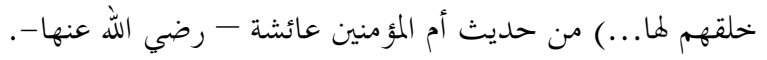

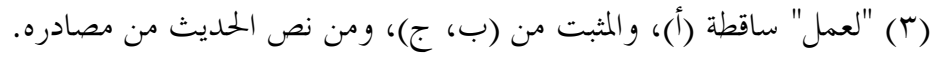

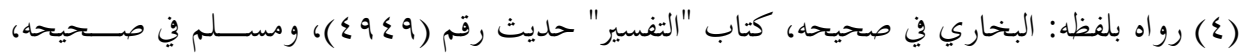

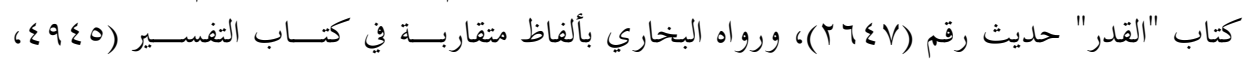

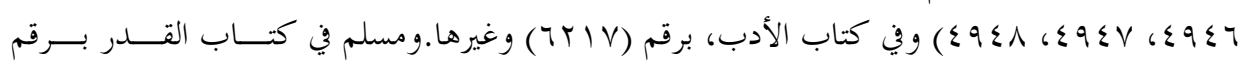

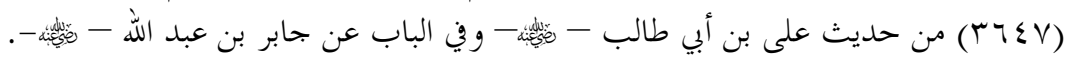

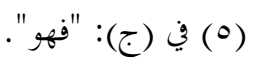

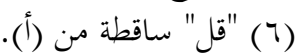

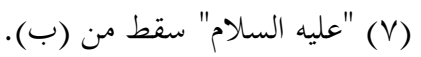
$-H_{T}$ 
و منهم طائفة يغترون( ') بما يكصل لهم من خرق عادة - مثل مكاشفة('). أو استجابة دعوة مخالفة للعادة العامة، ونحو ذلك- فيشتغل (r) أحدهم عما أمر به من العبادات (ع) و الشكر، و نخو ذلك. فهذه الأمور و نهوها كثيرا ما تعرض (0) لأهل السلوك و التوجه، وإنما ينجو العبد منها بمالازمة(7) أمر الله الذي بعث به رسوله في كل وقت كما قال الزهري (v) - ـرحمه الله - : كان من مضى من سلفنا يقولون:

$$
\text { (1) }
$$

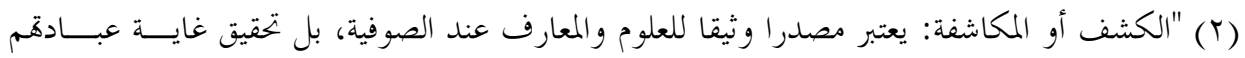

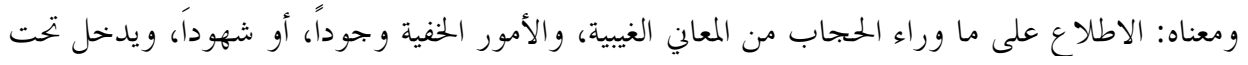

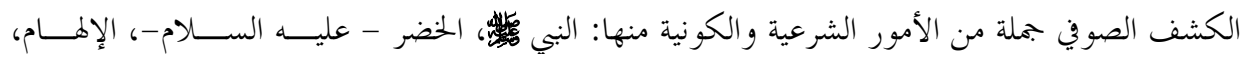

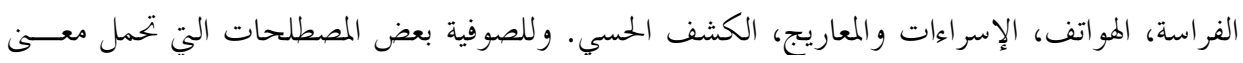

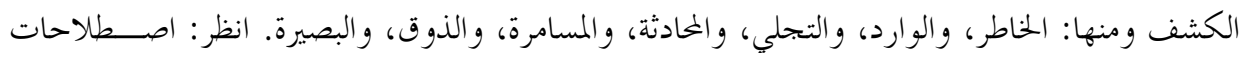

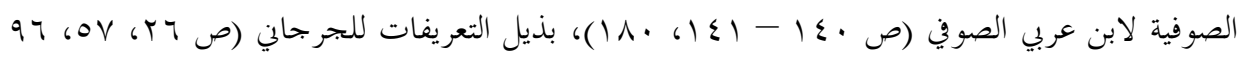

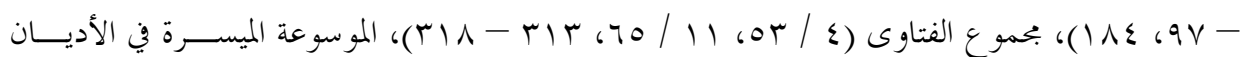

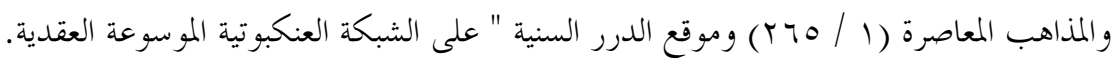

$$
\begin{aligned}
& \text { (r) من قوله "فيشتغل أحدهم" إلى قوله "ونحو ذلك" ساقطة من (ب). }
\end{aligned}
$$

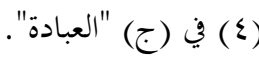

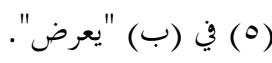

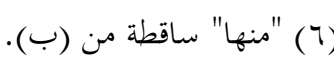

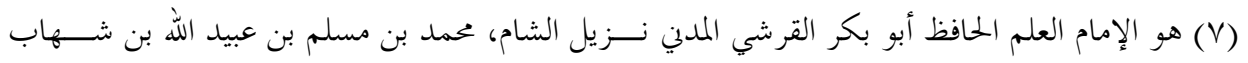

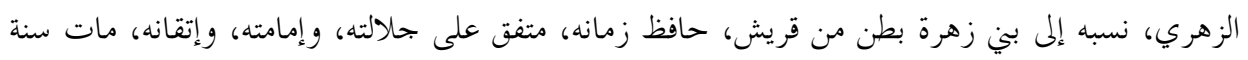

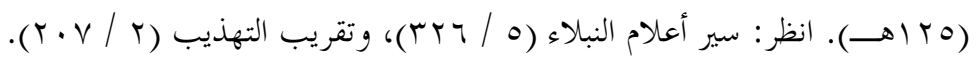




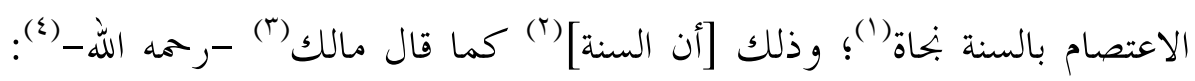

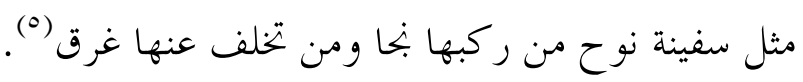
والعبادة، والطاعة، والاستقامة، ولزوم الصراط المستقيم، ونهو ذلك ريك من الأسماء

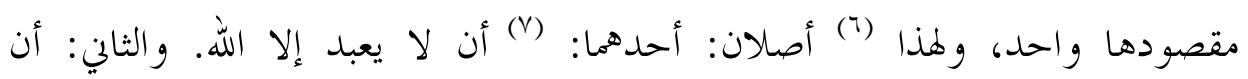

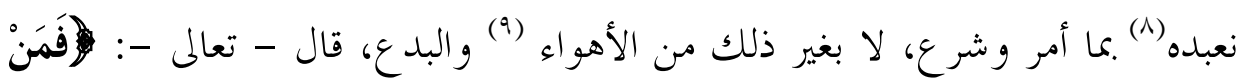

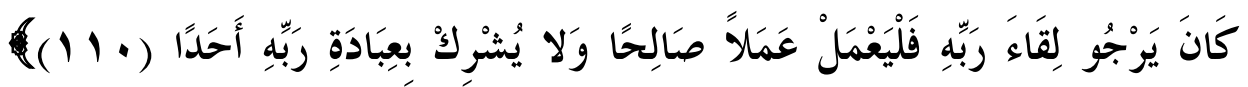

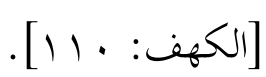

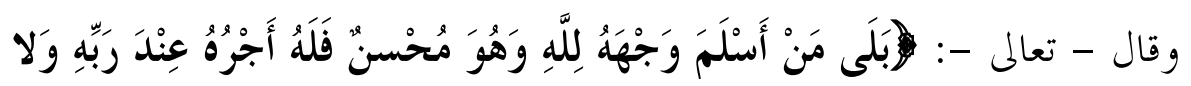

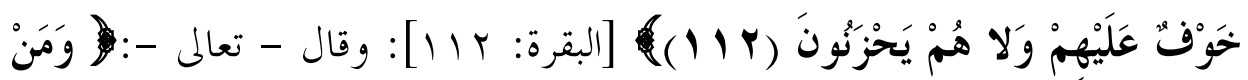
(1) ورد هذا الأثر في شرح أصول اعتقاد أهل السنة والجماعة، للالكائي (1 / ج ه)، والآداب الشــرعية

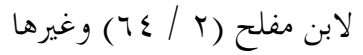

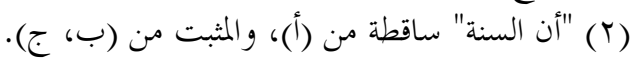

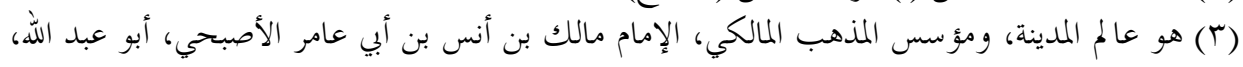

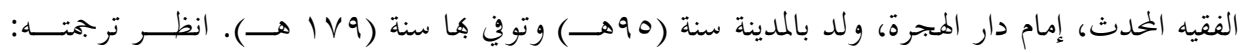

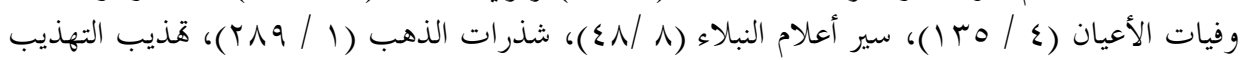

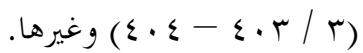

$$
\begin{aligned}
& \text { (ع) "رحمه الله" ساقطة من (ب) وغرها. }
\end{aligned}
$$

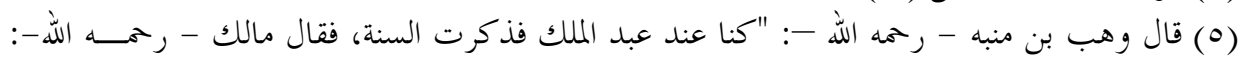

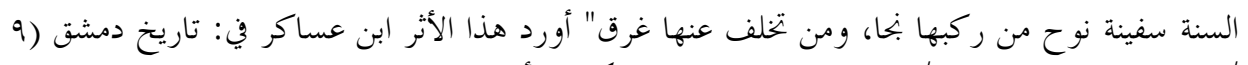

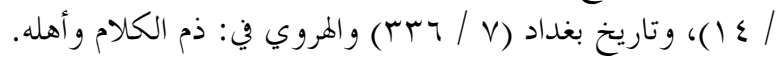

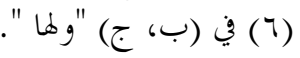

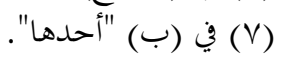

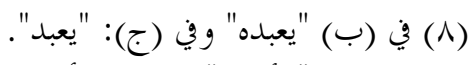

$$
\begin{aligned}
& \text { (9) في (ب) "الأهواء" زائدة في (أ). }
\end{aligned}
$$




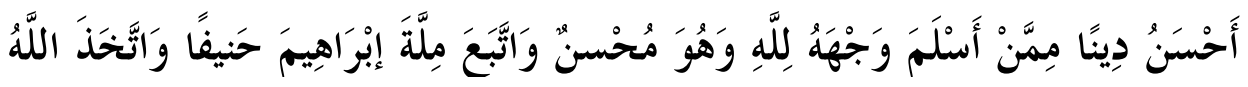

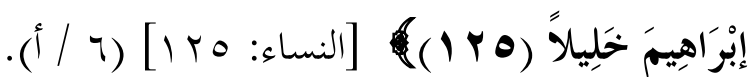

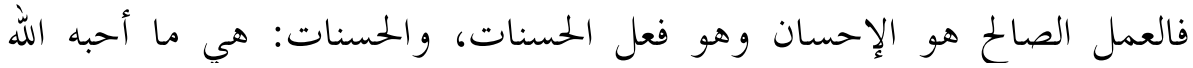

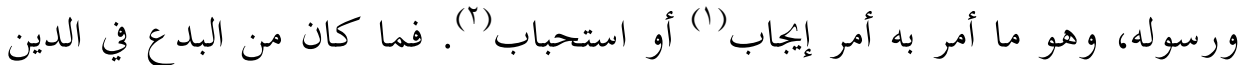

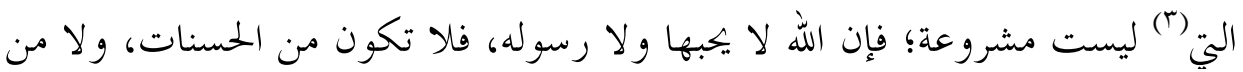

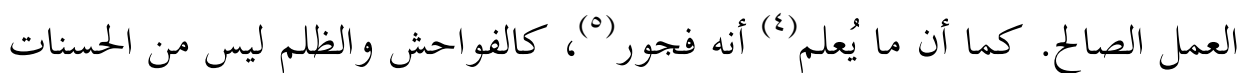
ولا من العمل الصالح.

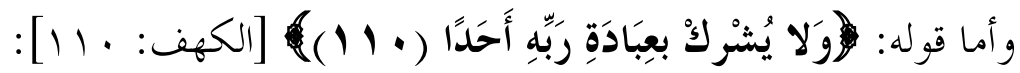

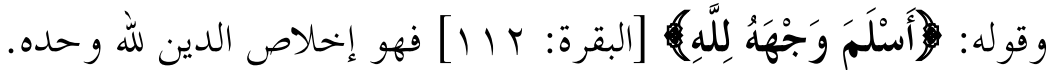

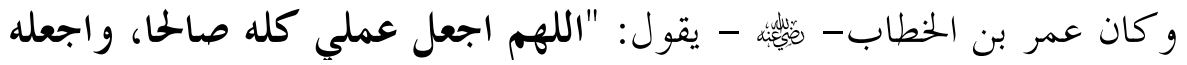
لوجهك خالصا، ولا تجعل لأحد فيه شيئا"()".

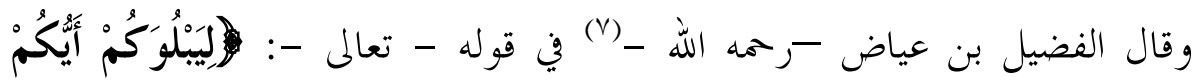

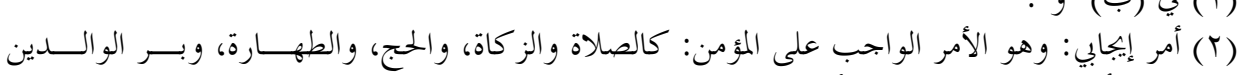

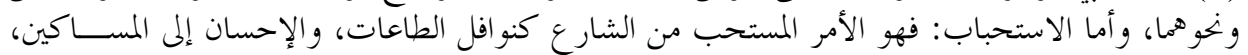

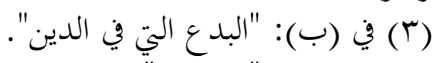

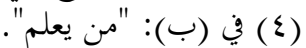

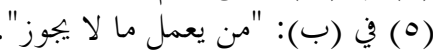

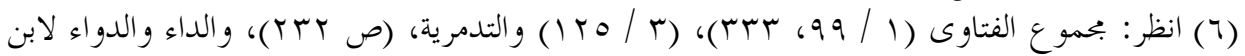

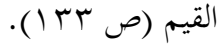

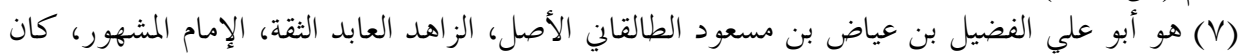

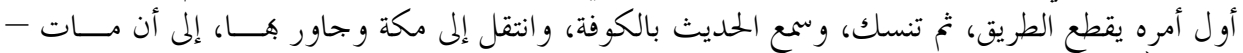

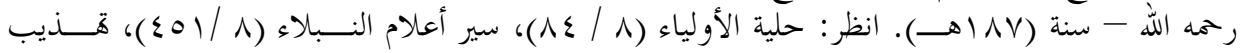

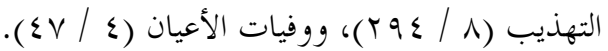




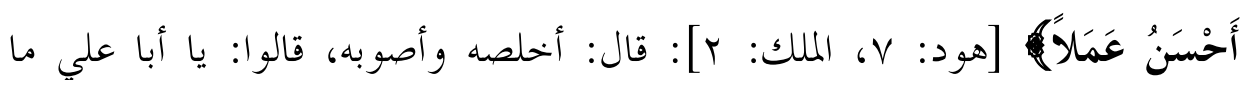

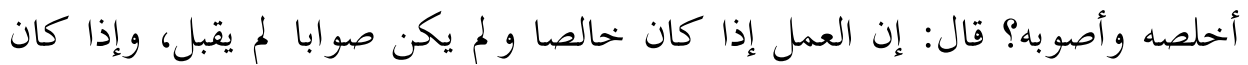

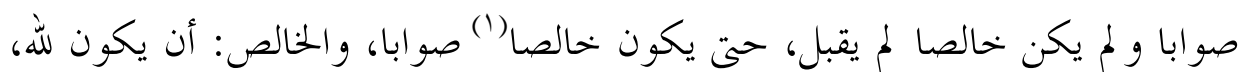
و الصو اب: أن يكون على السنة (؟).

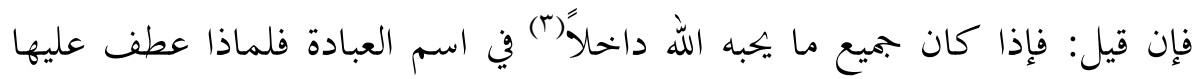

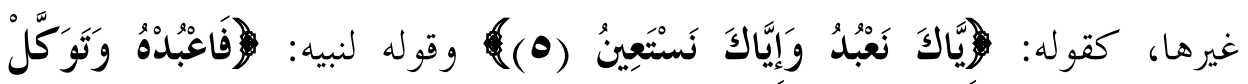

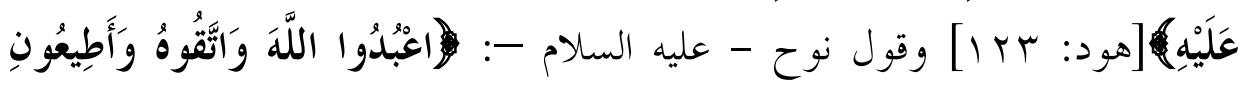
(r) (ب) [نوح: r]، و كذلك قول غيره من الرسل؟ قيل: هذا له نظائر كما في قوله:

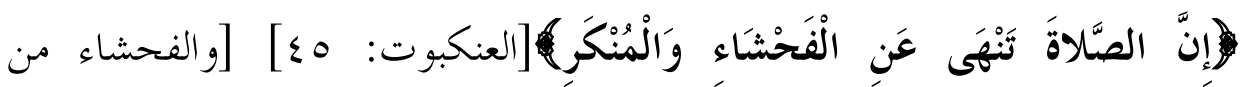
(घ) [المنكر

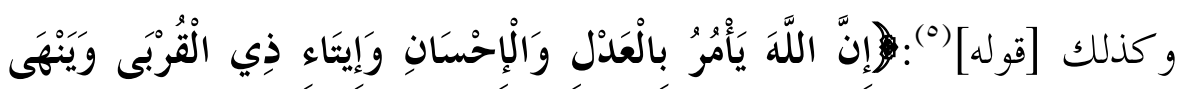

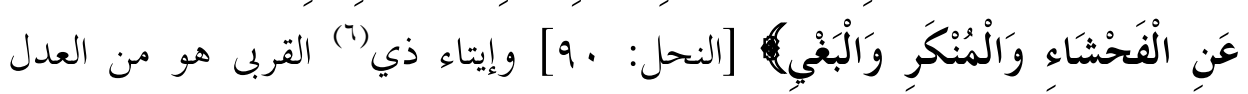

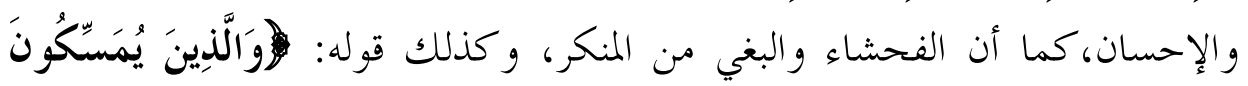

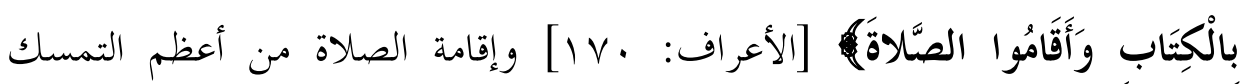

$$
\text { (1) (1) في (أ) " صالحا " و التصويب من (ب) و(ج). }
$$

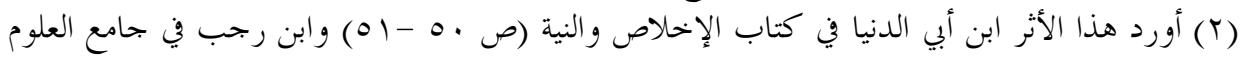

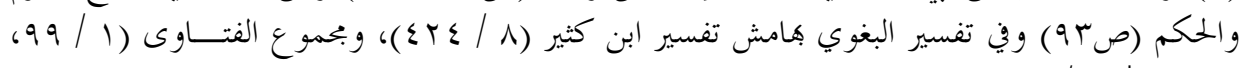

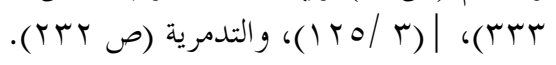

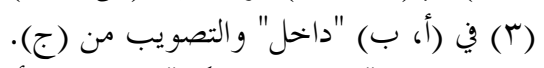

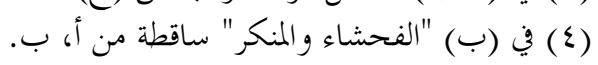

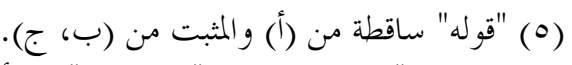

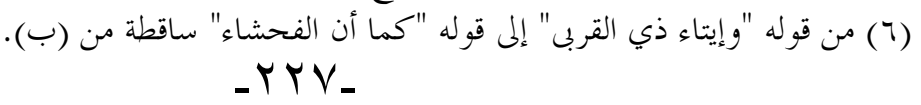




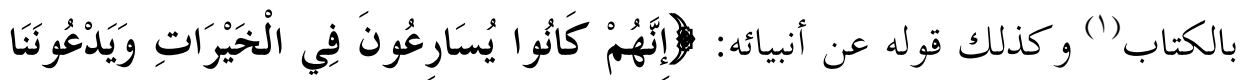

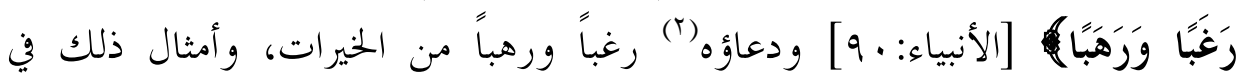

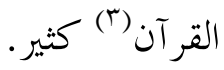

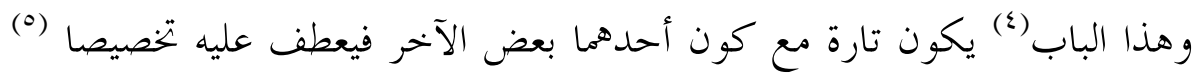
له بالذكر؛ لكونه مطلوبا بالمعني العام، و المعني الخاص.

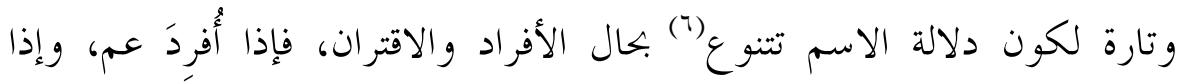

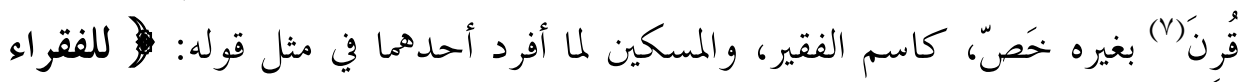

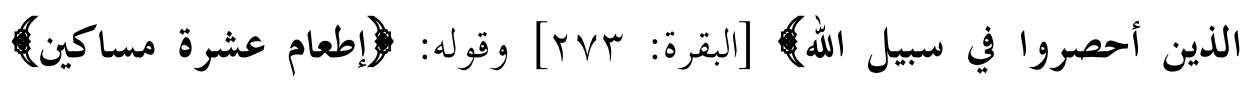

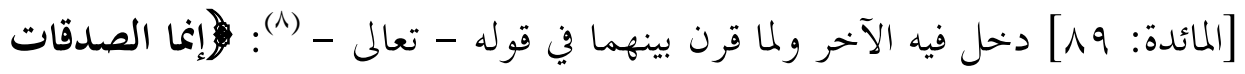

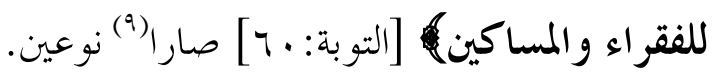
وقد قيل: إن الخاص المعطوف على العام لا يدخل في العام حال الاقتران، بل

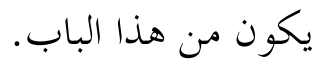

(1) (1) من قوله [وأقاموا الصلاة] إلى هنا ساقط من (أ) و (ب) والمثبت من (ج).

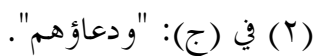

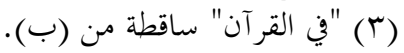

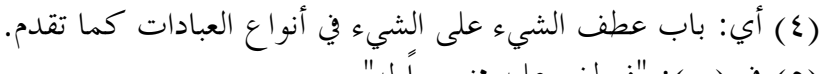

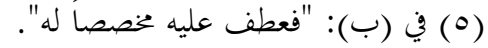
(ب) (ب)

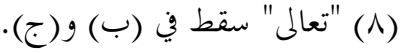

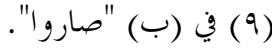




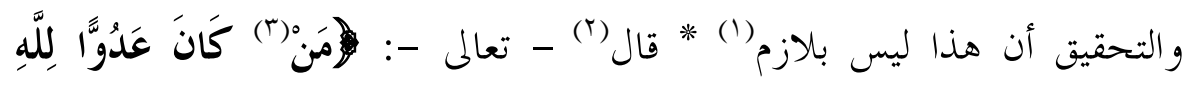

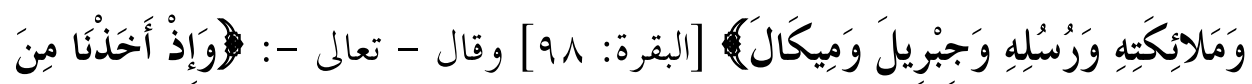

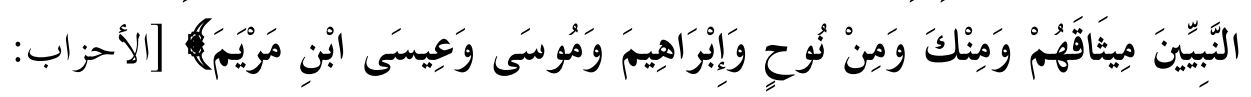

وذكر الخاص مع العام يكون لأسباب متنوعة: تارة لكونه له خاصية ليست لسائر

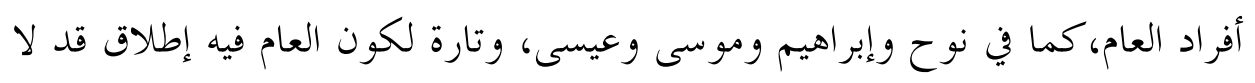

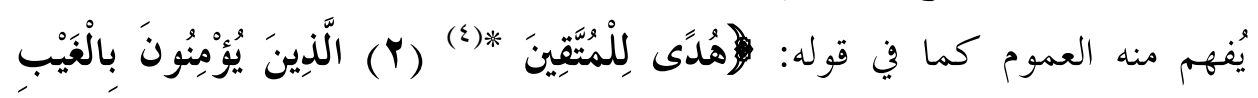

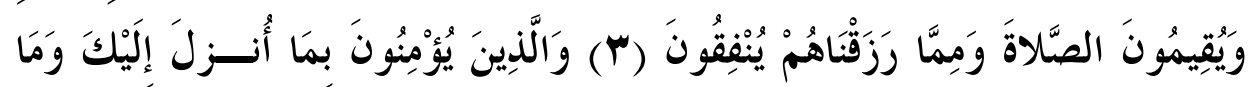

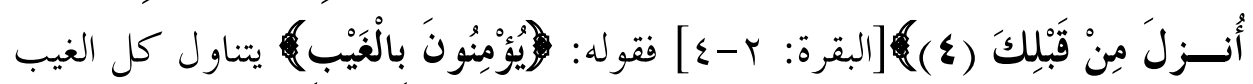

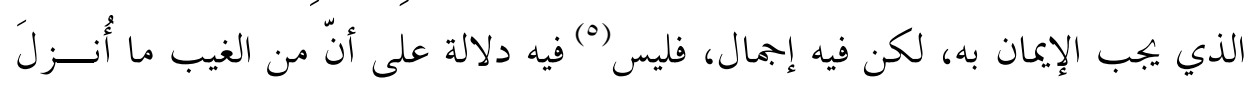

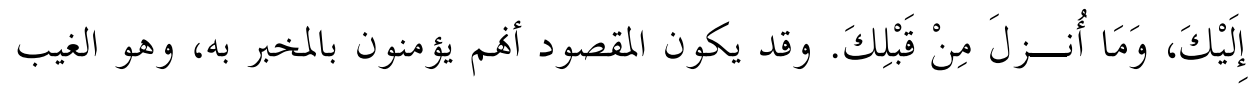

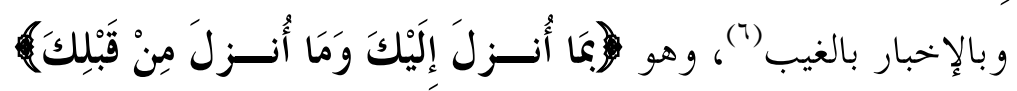

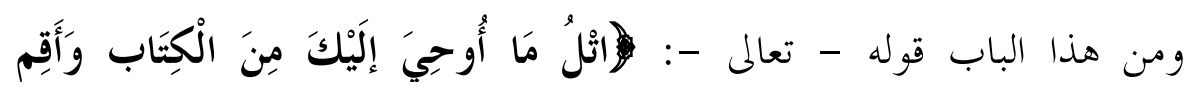

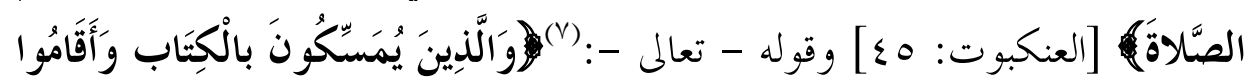

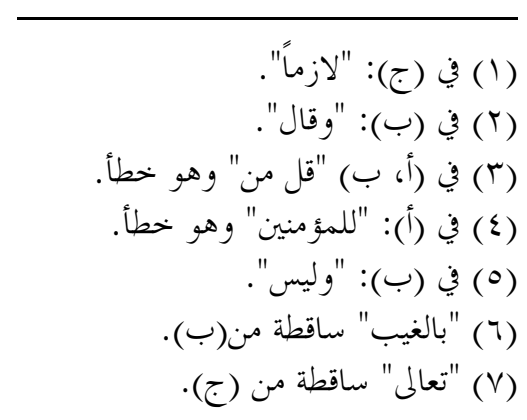




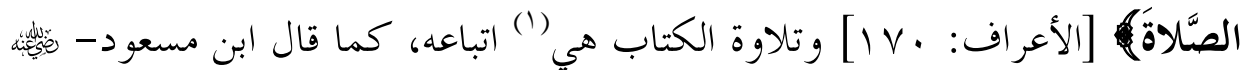

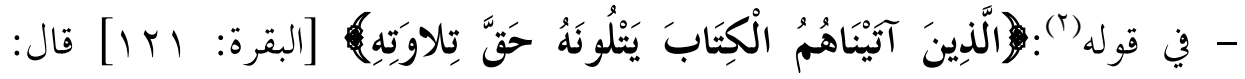

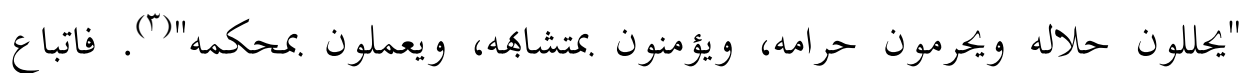

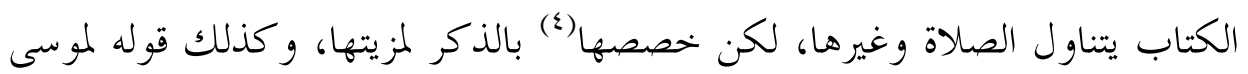

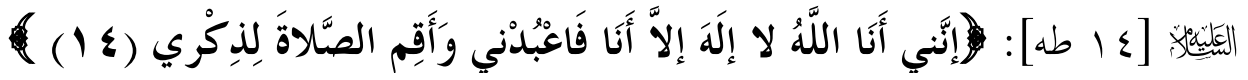

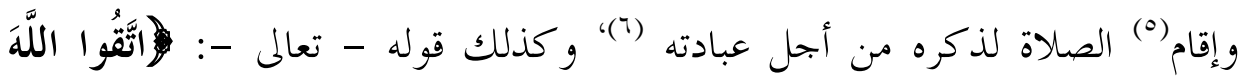

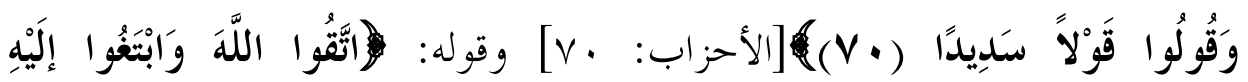

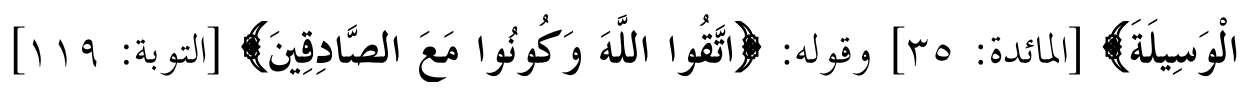

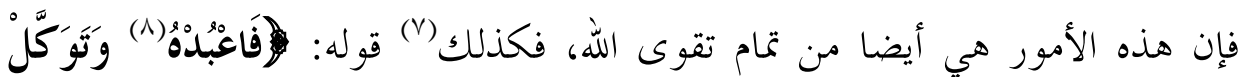

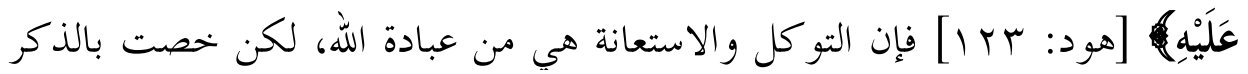

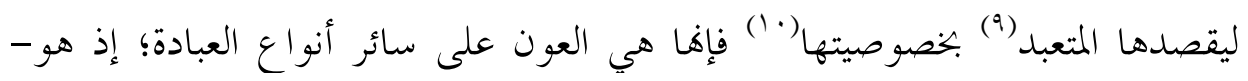
سبحانه- لا يعبد إلا بمعو نته.

$$
\text { (Y) }
$$

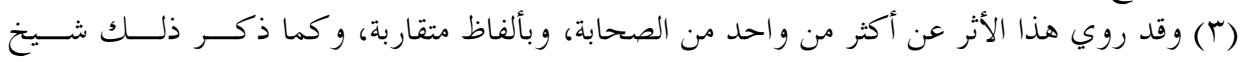

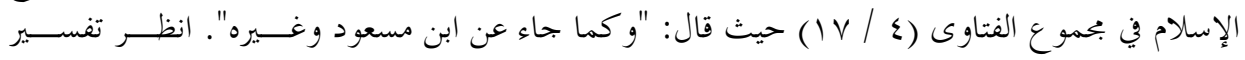

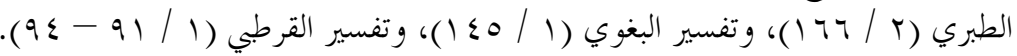

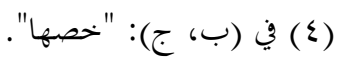

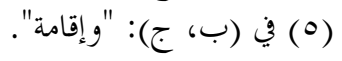

$$
\begin{aligned}
& \text { (7) (ך) في (ب): "عباداته". }
\end{aligned}
$$

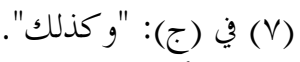

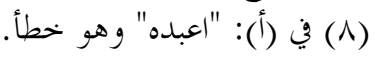

$$
\begin{aligned}
& \text { (9) (9) في (ب): "العبد". } \\
& \text { (1) في (ب، ج): "بخصوصها". }
\end{aligned}
$$


إذا تبين هذا فكمال المخلوق في تحقيق عبودية الله(1)، و كلما ازداد(r) العبد تحقيقا للعبودية ازداد كماله وعلت درجته، ومن توهم أن المخلوق يخرج من العبودية بوجهه

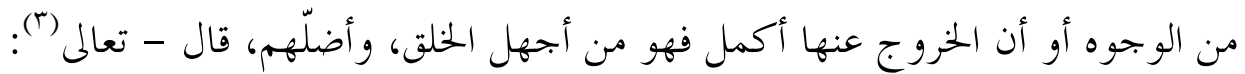

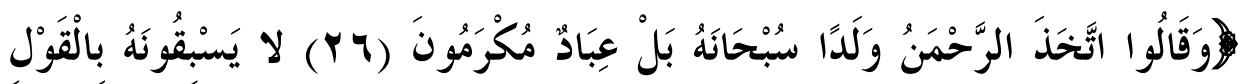

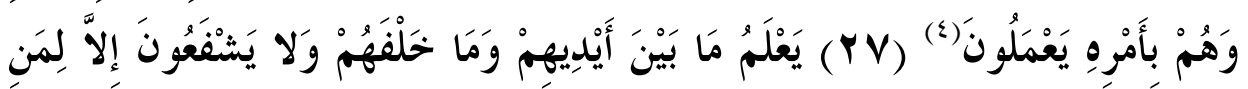

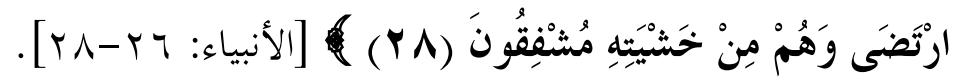

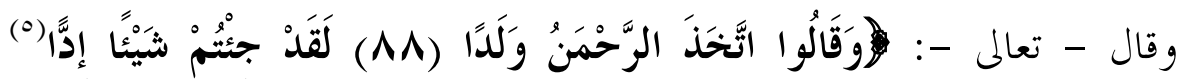
(19)

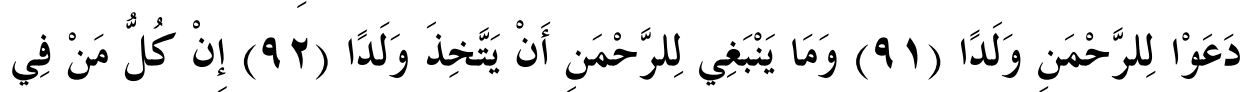

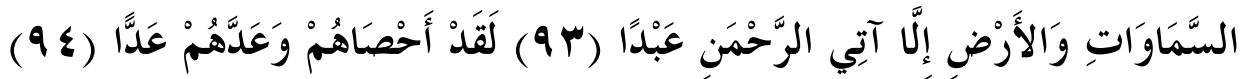

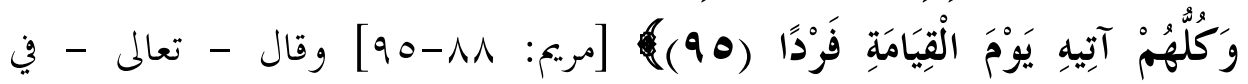

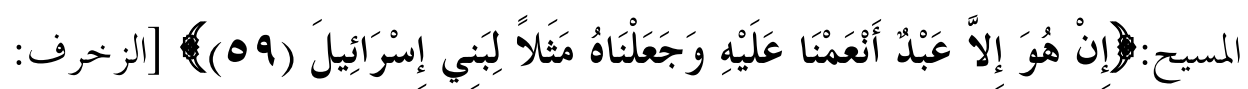

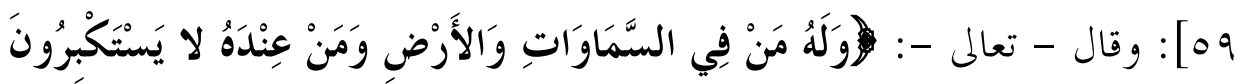

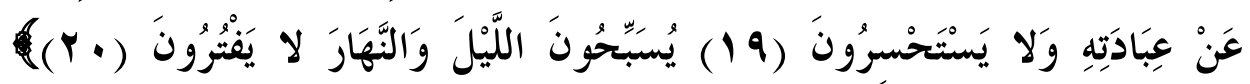

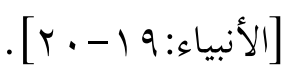

$$
\begin{aligned}
& \text { (1) في (ب، ج): "إن "عبوديته لله". }
\end{aligned}
$$

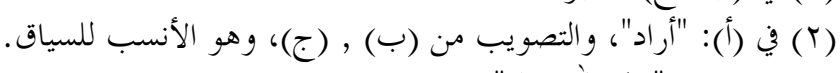

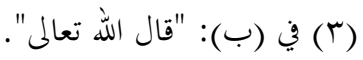

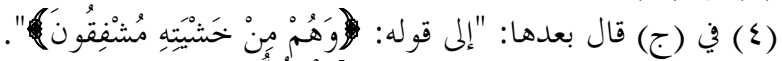

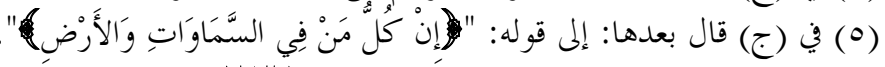

$$
\begin{aligned}
& \text { ـ ـ ـ ـ }
\end{aligned}
$$




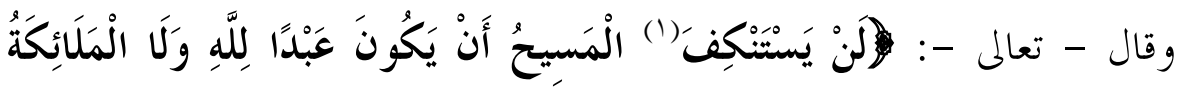

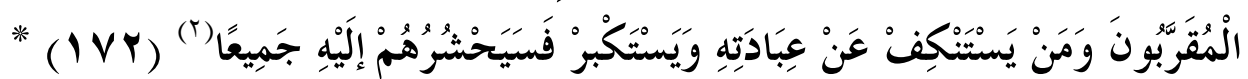

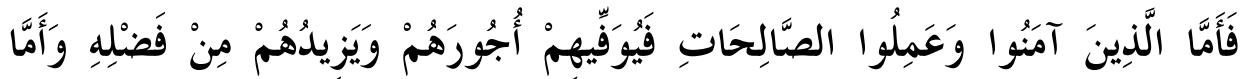

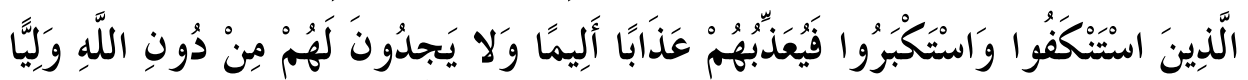

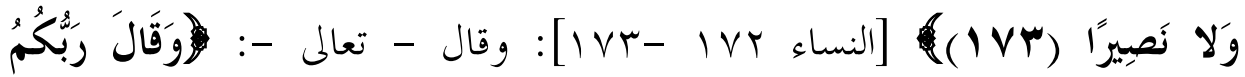

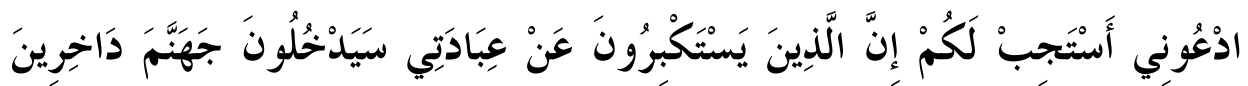

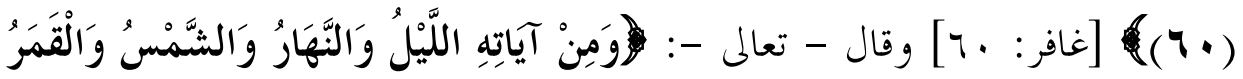

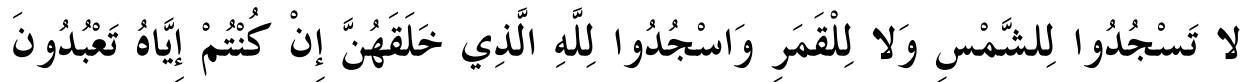

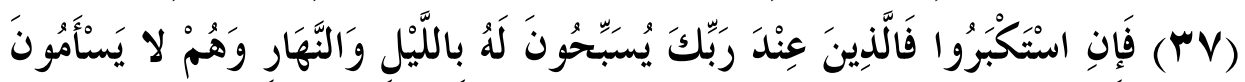

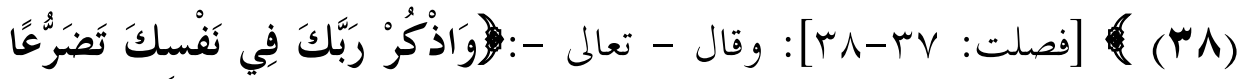

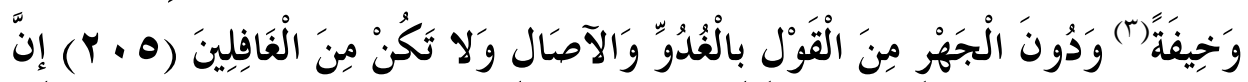

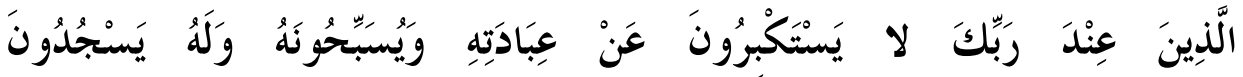

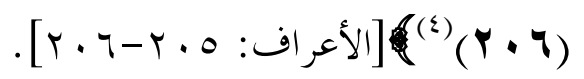

وهذا ونغوه مما فيه وصف أكابر الخلق بالعبادة، وذمه (o) من خرج عن ذلك متعدد

(1) الاستنكاف: هو التكبر والامتناع مع الأنفة فهو أشد من الاستكبار. و والاستكبار: هو العلو والتكسبر

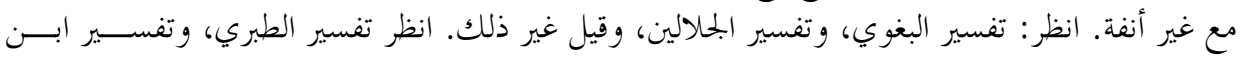

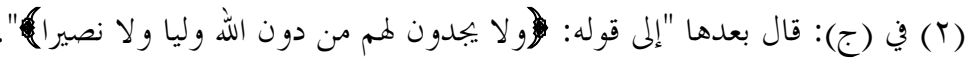

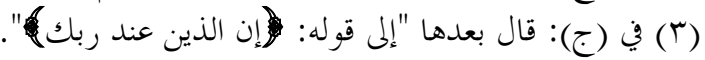

$$
\begin{aligned}
& \text { (ع) ) في (ب): "ولا يسحدون" وهو خططأ، ولعله تصحيف، أو خطأ من النساخ. }
\end{aligned}
$$

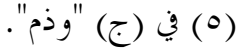$$
- \text { - TMt }
$$ 
في * القرآن، وقد أخبر الله (1) أنه أرسل جميع الرسل بذلك فقال - تعالى -: لووَمَا

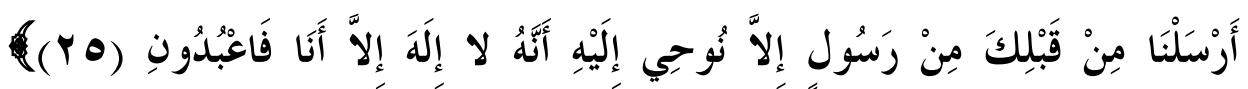

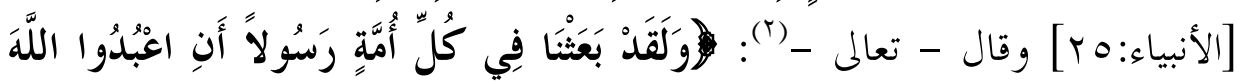

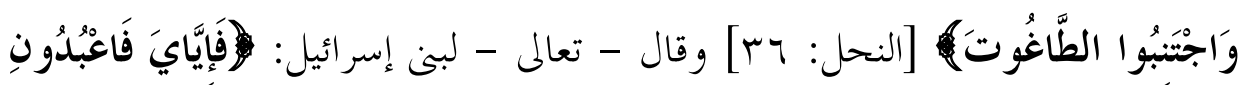

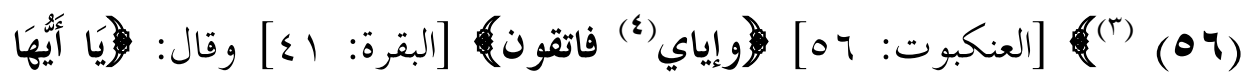

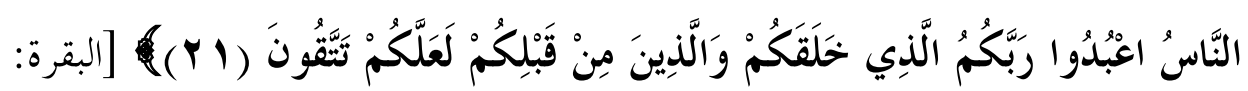

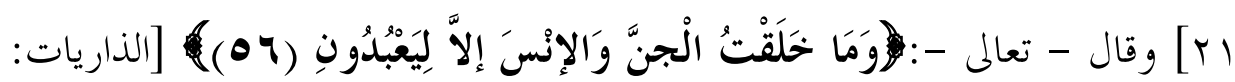

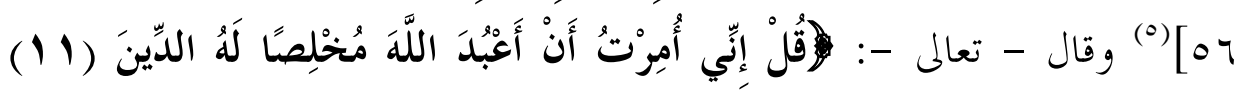

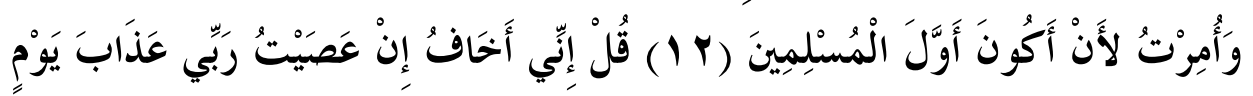

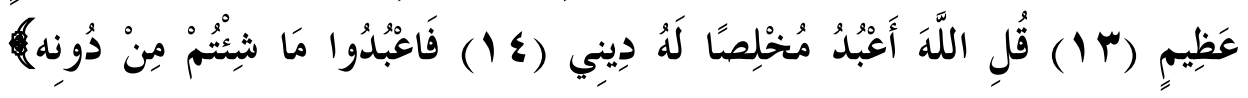

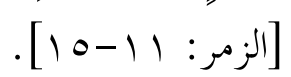
وكل رسول من الرسل افتتح دعوته بالدعاء إلى عبادة الله كقول نوح ومن بعده-

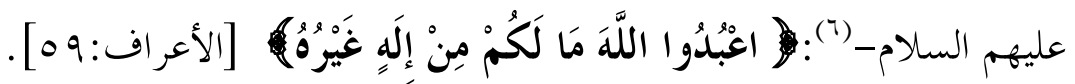

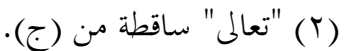

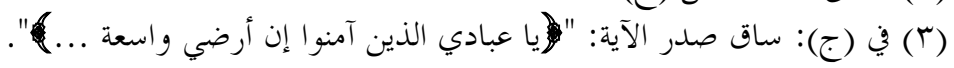
(ع) في (ب): "فإياي" وهو خطأ، ولعله الآية تصحيف.

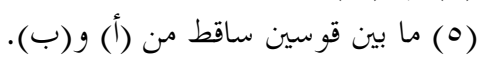
(7) "عليهم السلام" زائدة في (أ) و (ج). (ج). 


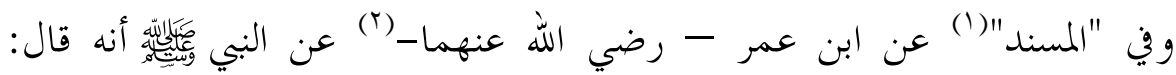
"بعثت بالسيف بين يدي الساعة حتى يعبد الله وحده لا شريك له،وجعل رزقي تحت ظل رمحي، و جعل الذلة والصغار على من خالف أمري"("َ).

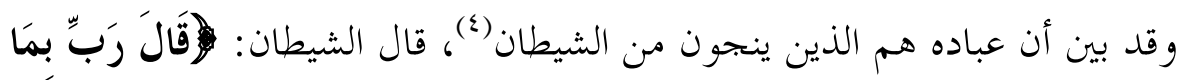

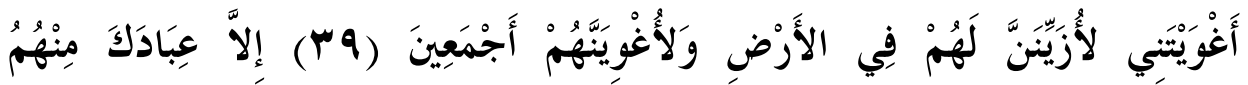

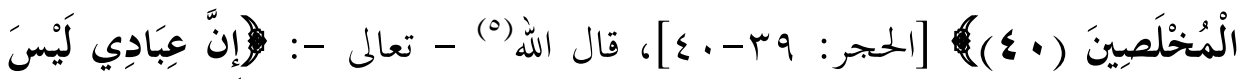

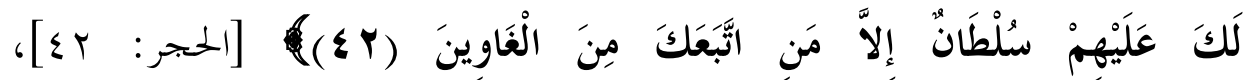

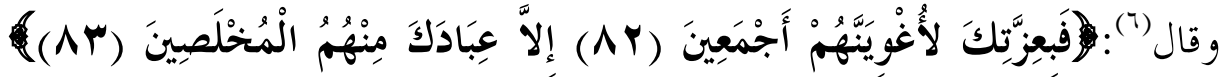
. $[\Lambda r-\Lambda r: ص]$

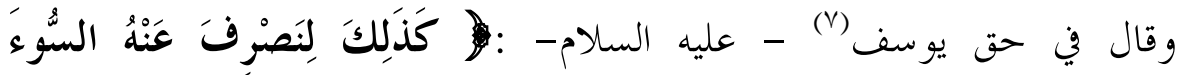

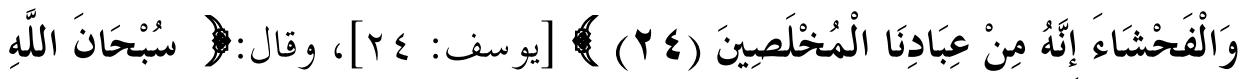

$$
\begin{aligned}
& \text { (1) أي: في مسند الإمام أحمد - رحمه الله - وهو كما قال، ورواه غيره كما سيأتي. } \\
& \text { "هاية (· / / ب ب). }
\end{aligned}
$$

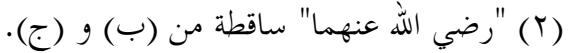

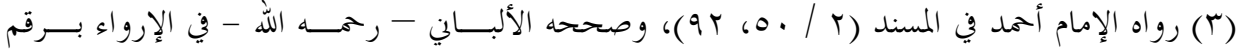

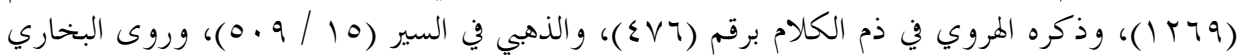

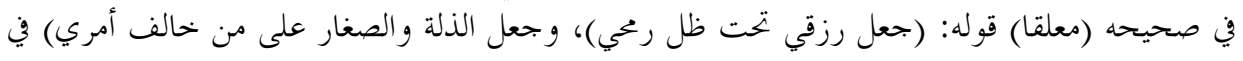
كتاب "الجهاد" باب "ما قيل في (كعل الرمح".

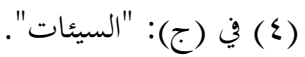

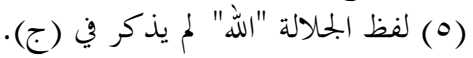
( ) (7) في (ب): "قال".

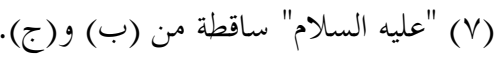




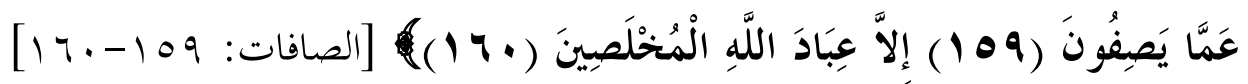

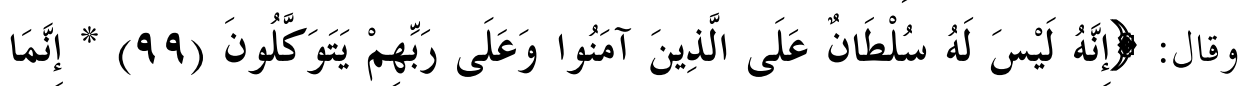

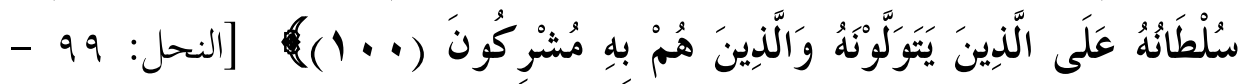
. [1..

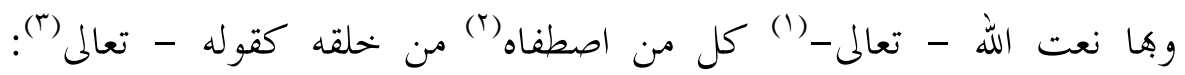

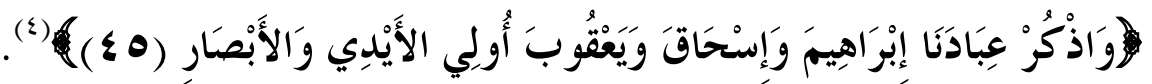

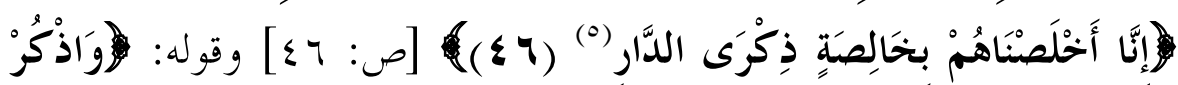

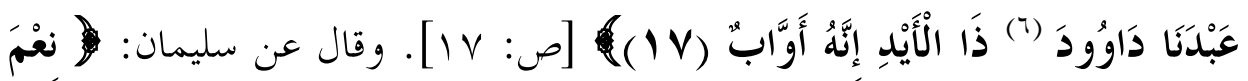

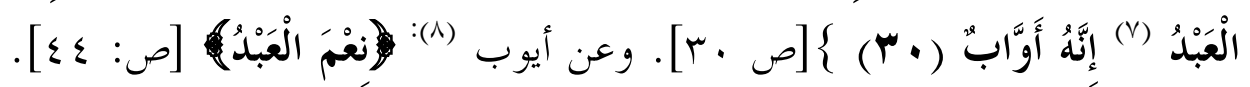

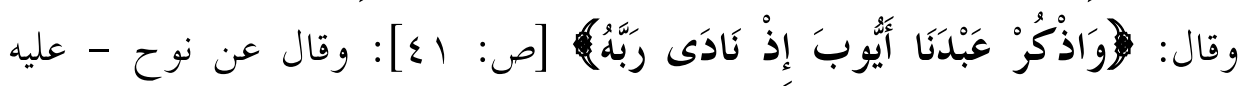

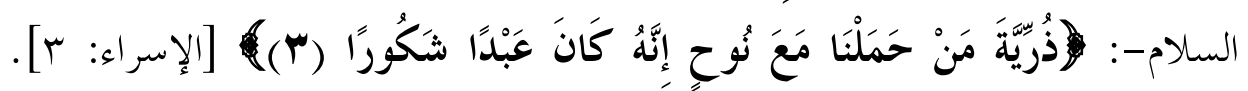

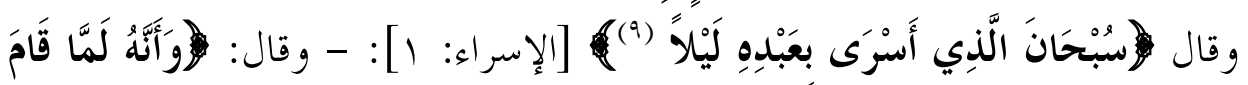

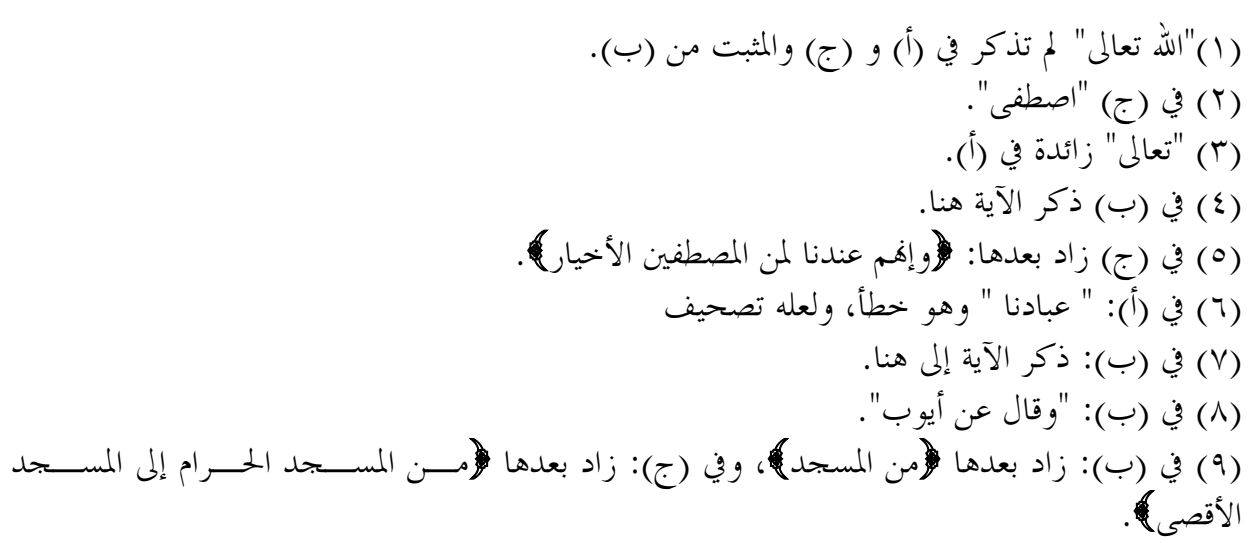




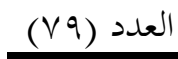

مجلة الدراسات الأسلامية والبحوث الأكاديهية

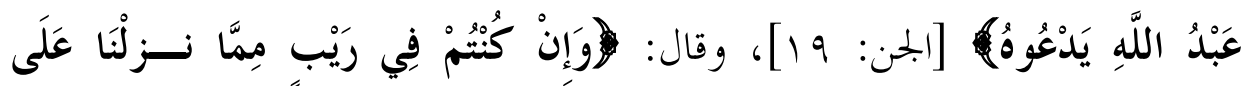

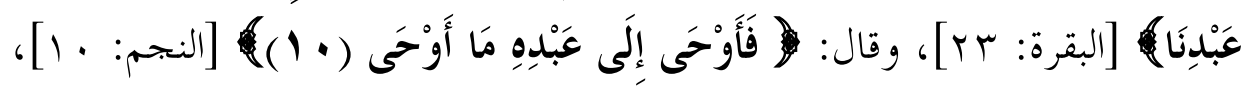

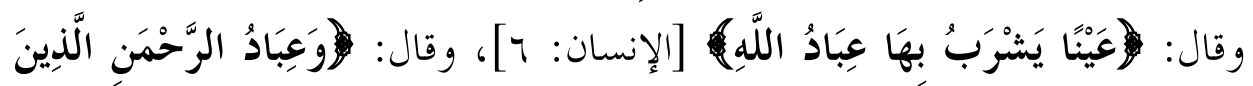

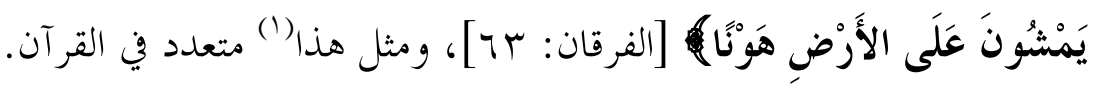
***

- YTI 


$$
\text { العبودية لشيخ الإسلام: أحمد بن تيمية "اר؟ - }
$$

\section{فهرست المصادر والمر اجع}

$$
\text { القر آن الكريم }
$$

1- الإبانة عن أصول الديانة، لأبي الحسن علي بن إسماعيل، تقديم حماد بن أحمد الأنصاري، الطبعة الثانية، 0ــاهــ، مطابع الجامعة الإسلامية بالمدينة

$$
\text { المنورة. }
$$

r - - الإبانة عن شريعة الفرقة الناجية ومجانبة الفرقة المذمومة، الإمام أبو عبد الله ابن بطة العكبري الحنبلي بتحقيق رضا بن نعسان، دار الراية، الرياض، الطبعة

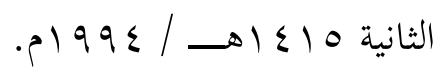

r- - أحكام أهل الذمة، المؤلف: لشمس الدين أبي عبد الله محمد بن أبي بكر ابــنـ قيم الجوزية المققق: صبحي الصالح، دار العلم للملايين، بيروت الطبعة الرابعة،

$$
\text { . }) 99 \varepsilon
$$

ع - أحكام القرآن، للقاضي محمد بن عبد الله أبو بكر بن العربي، تحقيق: علــي

$$
\text { البجاوي، دار المعرفة، بيروت، لبنان. }
$$

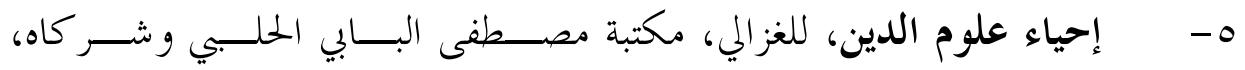
. $\rightarrow$ Tron

؟- ـ الاستقامة، لابن تيمية، المققق: د. محمد رشاد سالم، مكتبة السنة، القـــاهرة،

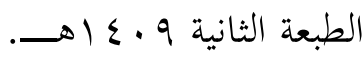

- V - الأسماء و الصفات للبيهقي، المؤلف: لإمام الحافظ أبي بكر أحمد بن الحســين 
البيهقي، حققه: عبد الله بن محمد الحاشدي، مكتبـــة الســـوادي، جــــة $\rightarrow \infty \leqslant$

^- - الإصابة في تمييز الصحابة، لابن حجر العسقلاني، و.هامشه الاستيعاب لابــن

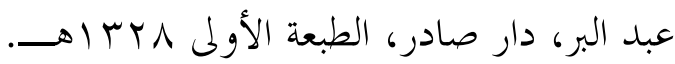
9- - الاعتصام للإمام الشاطبي، تحقيق: سليم بن عيد الهــلالي، دار ابــن عفـــان،

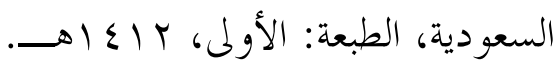

• ا - الاعتقاد على مذهب السلف، لإمام أبي بكر البيهقي، دار الكتب العلميــة،

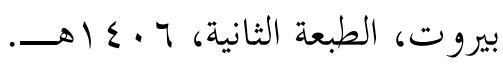
ا1- اعتقادات فرق المسلمين والمشركين، لفخر الدين محمد الـــرازي، تحقيــق:

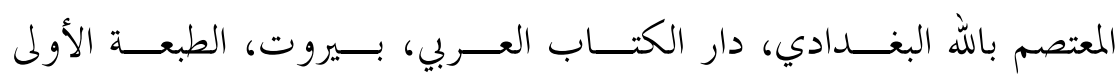
.$\rightarrow \sum \cdot V$ r ا - الأعلام، لخير الدين الزركلــي، دار العلـــم، بــيروت، الطبعــة الخامســة، . $\rightarrow \leqslant \ldots$ با - إعلام الموقعين عن رب العالمين، للإمام ابن القيم الجحوزية، محمد عبد الســلام

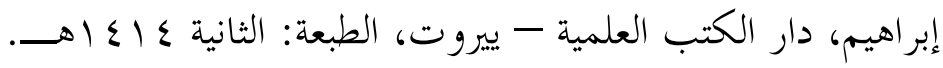

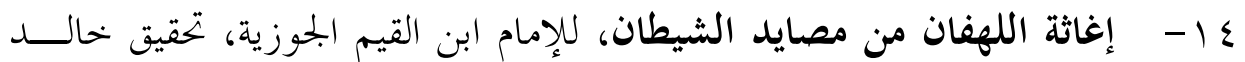

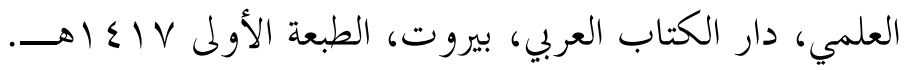
10 - اقتضاء الصراط المستقيم لمخالفة أصحاب الجحيم،لشيخ الإسلام ابن تيمية،

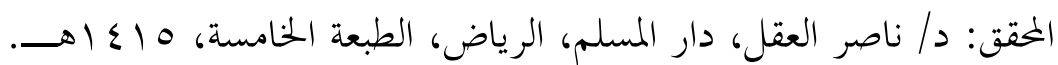


7 - الأمر بالمعروف والنهي عن المنكر، لشيخ الإسلام ابن تيمية، عنايــة: أبـــ

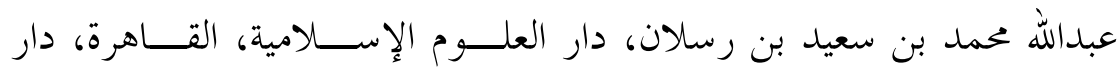

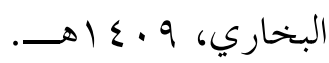

IV - إيثار الحقى على الحلق، ابن الوزير، محمد بن إبراهيم، دار العلــم، بــيروت، 11

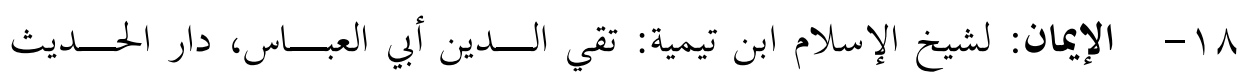

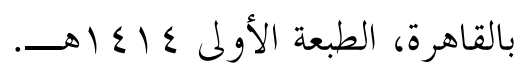

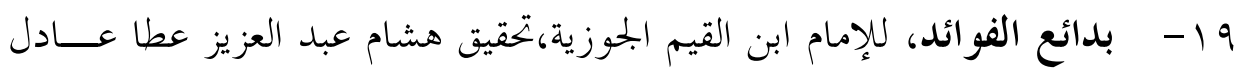

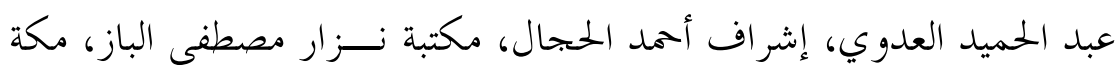

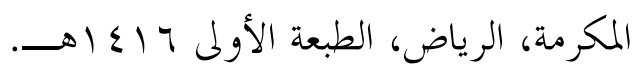

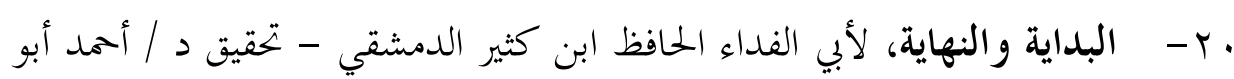

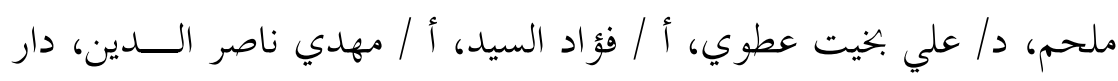

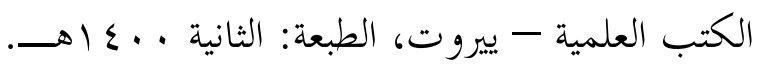

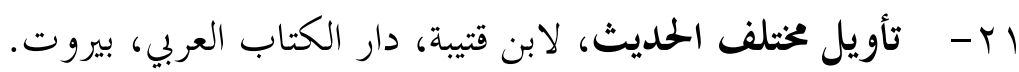

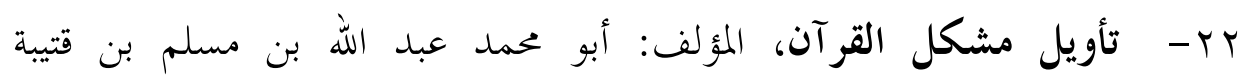
الدينوري، شرح السيد / أحمد صقر، دار الطباعة المكتبة العلمية.

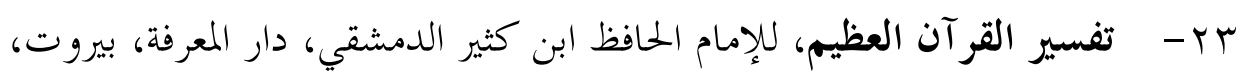

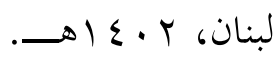
ع - قريب التهذيب، للإمام الحافظ شهاب الدين أحمد بن علي بن حجر

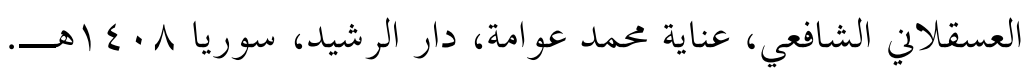


0 - ت تلبيس إبليس، لابن الجوزي، تحقيق السيد الجميلي، دار الكتاب، بيروت. بr- التنبيه والرد على أهل الأهواء والبدع، أبو الحسين المَلَطي العسقلاني،

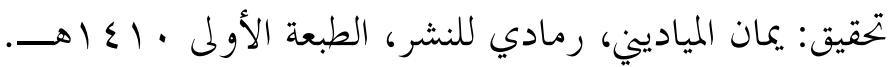

تحذيب الآثار، لأبي جعفر الطبري، الخحقق: محمود محمد شاكر، مطبعة المدني. 人 - - التوبة، لابن القيم الجوزية،تحقيق صابر البطاوي، دار الأندلس جدة، الطبعة

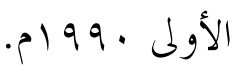

وץ- - التوحيد، أبو عبد الله بن مَنْده، حققه: الدكتور علي الفقيهي، مكتبة الغرباء

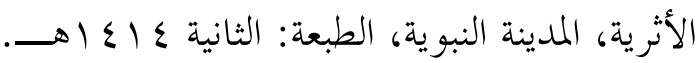
• ب- جامع البيان في تفسير القرآن، لإمام الطبري، دار المعرفة، بيروت، لبنــان، . $-0 \leqslant 1 \%$

اسب- حلية الأولياء، لأبي نعيم الأصفهاني، دار الكتب العلمية - ييروت، الطبعــة: الثانية و . ع اهـ.

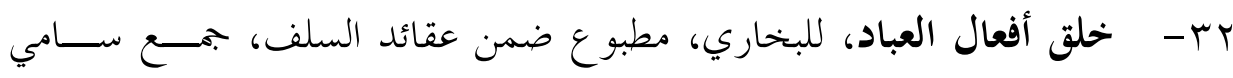
النشار، وعمار الطابي، منشأة المعارف بالإسكندرية.

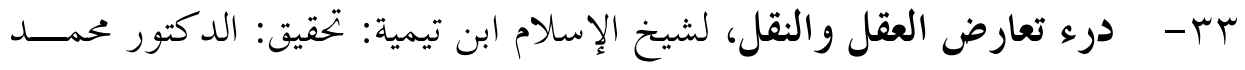

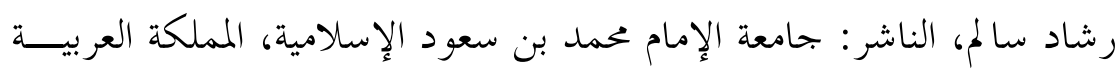

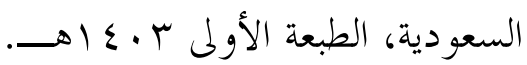
ع ب- - الدين الحالص، محمد صديق حسن، تحقيق محمد زهري النجار، دار التراث، القاهرة. 


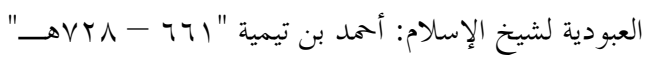

د. منيرة بنت عبد الله الراجحي

هب- ـ الروح، للإمام ابن القيم الجوزية، تحقيق السيد الجميلي، دار الكتاب العـــبي، الطبعة الثانية 7 إعاهـــ

بس- - زاد المعاد في هدي خير العباد، للإمام ابن القيم الجوزية، مكتبـــة الريــاض

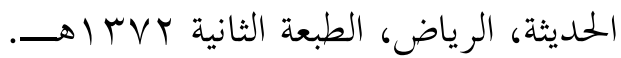

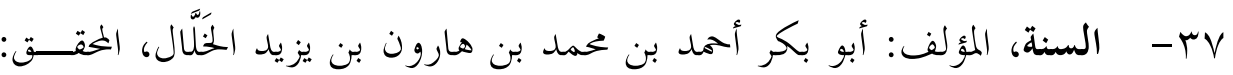

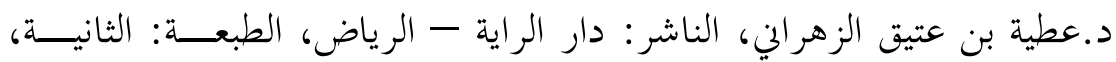
. $\rightarrow \leqslant 10$

مץ-- السنة، المؤلف: أبو عبد الرحمن عبد الله بن أحمد بن محمد بن حنبل إمام أهل السنة، المحقق: د. محمد بن سعيد بن سالم القحطاني الناشر: دار ابن القــيم -

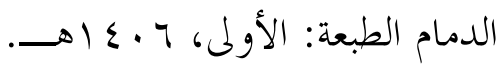

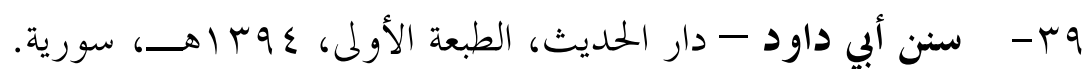

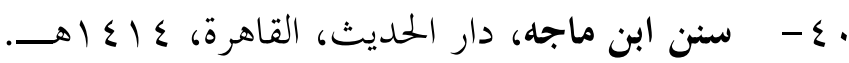

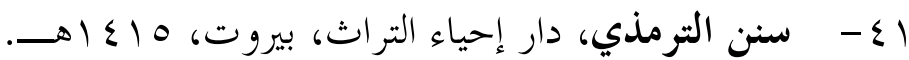

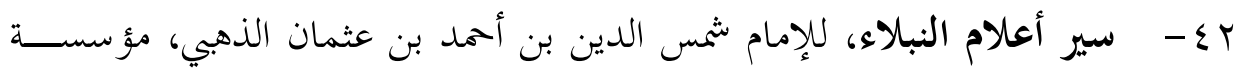

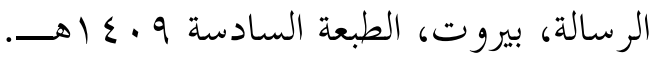
rع - شذرات الذهب في أخبار من ذهب، لابن العمـــاد الحنبلــي، دار الآفــاق

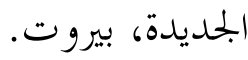

ع - - شرح أصول اعتقاد أهل السنة والجماعة، للإمام الحافظ أبي القاسم الطبري،

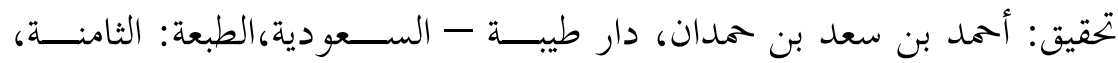


0ـ- - شرح السنة، لإمام أبي الحسن البرهاري، تحقيق: د/ محمد سعيد القحطاني،

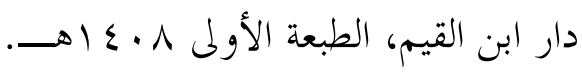

Tـ - شرح العقيدة الطحاوية، للإمام القاضي علي بن محمد أبي الفداء الدمشقي،

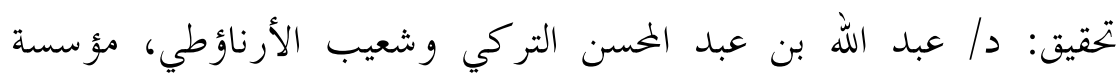

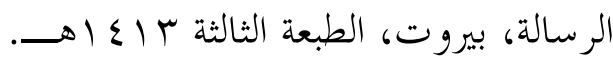
عV

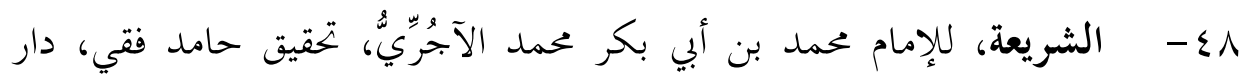
الباز، مكة المكرمة،دار الكتب، بيروت.

9 - - شفاء العليل في مسائل القضاء والقدر والحكمة والتعليل، للإمام شمس الدين ابن قيم الجوزية، تحقيق مصطفى الشبي، مكتبة السوادي، جدة، الطبعة الثانية، 10 إهـ.

•- - الصارم المسلول على شاتم الرسول، لشيخ الإسلام ابن تيمية، المحق: محمد محيي الدين عبد الحميد، الناشر: الحرس الوطني السعودي، المملكة العربية السعودية.

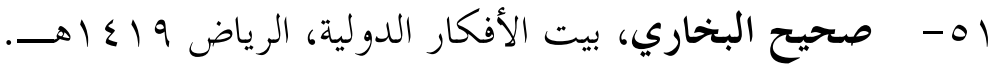

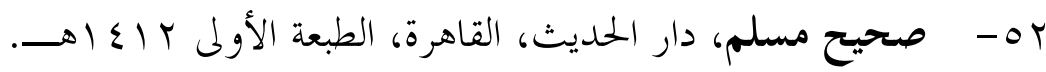

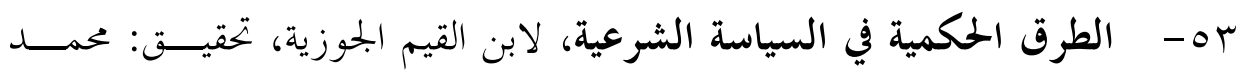
حامد الفقي، دار الكتب العلمية، بيروت. عه - طريق الهجرتين وباب السعادتين، لإمام شمس الدين ابن قيم الجوزية، تحقيق: 


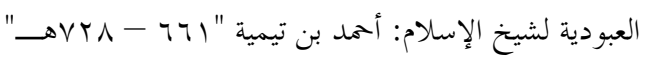

حازم القاضي، مكتبة الباز،مكة المكرمة، الطبعة الأولى 10

هـ - عقيدة السلف وأصحاب الححديث، لأبي عثمان الصابولن، تحقيق: د/ ناصر

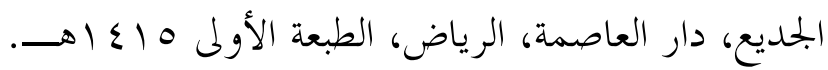

جه - الفتاوى الكبرى لابن تيمية، دار المعرفة، بيروت.

ف - OV - الجيد شرح كتاب التوحيد، لعبد الرحمن بن حسن بن محمد بن عبد الوهاب، تحقيق: ابن باز و الفقي، عناية صادق بن صادق، دار المنار بالرياض،

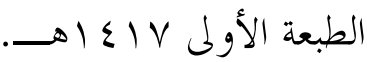

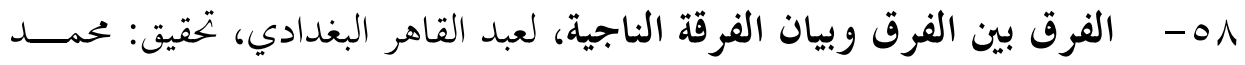

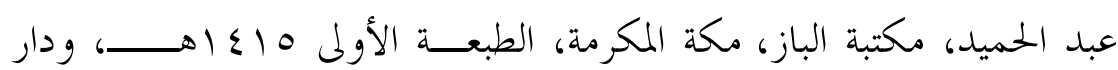

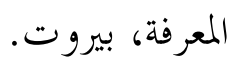

وه - الفروسية،لشمس الدين ابن قيم الجموزية، تحقيق: محمد الفتــيح، مكتبـــة دار

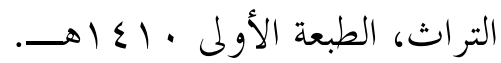

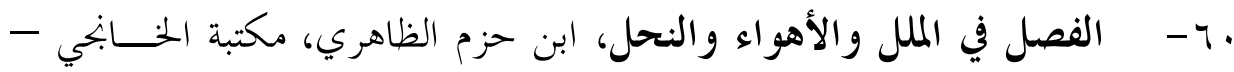

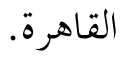

الج- - الفوائد، لشمس الدين ابن قيم الجوزية، تحقيق: محمد عثمان الخشت، دار الكتاب العربي، بيروت، الطبعة الثالثة م · ع اهـــ.

ץ با - قاعدة جليلة في التوسل والوسيلة، لشيخ الإسلام ابن تيمية، مطبعة معارف،

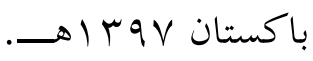

بح- قاعدة عظيمة في الفرق بين عبادات أهل الإسلام والإيمان وعبادات أهــل $-T \leqslant T-$ 
الشرك والنفاق، لشيخ الإسلام ابن تيمية، المحقق: سليمان بن صالح الغصن، دار العاصمة - الرياض، الطبعة: الثانية ماءـاهـــ. ع - - القضاء والقدر، لشيخ الإسلام ابن تيمية، ضبط وتعليق: أحمد السايع، والدكتور السيد الجميلي، دار الكتاب العربي، بيروت، الطبعة الثالثة

هـ - لمعة الاعتقاد، للإمام موفق الدين عبد الله بن أحمد بن محمد بن قدامة، الشهير بابن قدامة المقدسي، شرح الشيخ محمد بن صالح العثيمين، المققق: أشرف بن

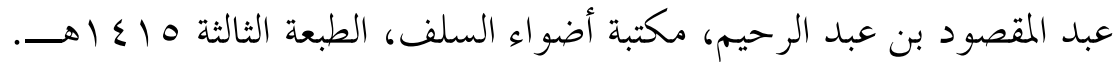
7 - - جموع فتاوى شيخ الإسلام ابن تيمية، جمع عبد الرحمن بن محمد القاسم،

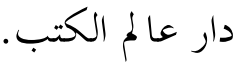
- TV مختصر الصواعق المرسلة على الجهمية والمعطلة، لشمس الدين ابن قيم

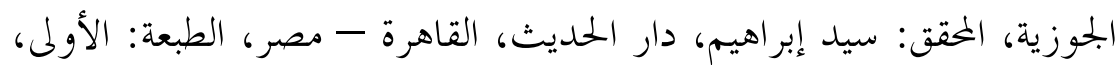
$. \rightarrow \leqslant r r$ 1 - - مدارج السالكين بين منازل إياك نعبد وإياك نستعين،لشمس الدين ابن قيم

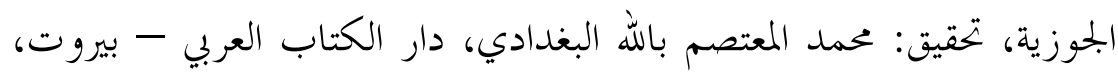
الطبعة: الثالثة، 7 إع اهـــ 79- المستَائلُ الماردينيَّة في فقه الكتاب والسنة، ورفع الحرج في العبادات والمعاملات، لشيخ الإسلام ابن تيمية، تحقيق: زهير الشاويش، المكتب

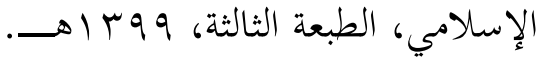




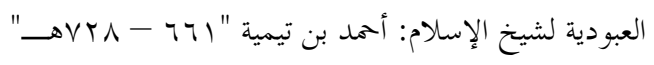

• - معارج القبول بشرح سلم الوصول إلى علم الأصول، حافظ بن أحمد بن

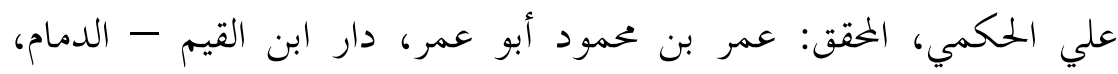

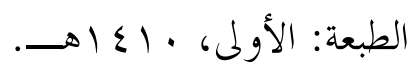

الم - مفتاح دار السعادة ومنشور ولاية العلم والإرادة، لشمس الدين ابن قيم الجوزية دار الكتب العلمية - بيروت.

- م - منهاج السنة النبوية في نقض كلام الشيعة القدرية، لشيخ الإسلام ابن

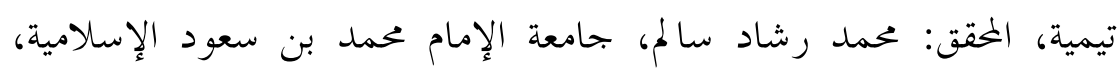

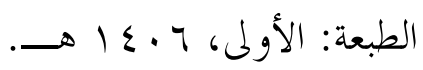

r - المنهج الأمد في تراجم أصحاب الإمام أحم، للعليمي، تحقيق: محمد عبد

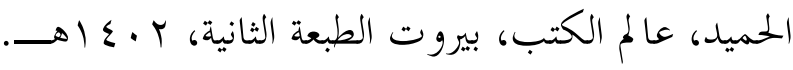
ع - ميزان الاعتدال في نقد الرجال، شمس الدين أبو عبد الله الذهبي، تحقيق: علي محمد البجاوي، دار المعرفة للطباعة والنشر، بيروت - لبنان، الطبعة: الأولى، .

ه - النبوات، لشيخ الإسلام ابن تيمية، دار الكتاب العربي، بيروت، الطبعة الأولى . $\rightarrow$. 10 
